\title{
Heteroplasmia em Bombus morio (Hymenoptera, Apidae) e impactos em estudos evolutivos
}

\author{
Paulo Cseri Ricardo
}

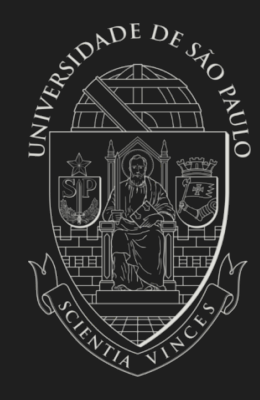

São Paulo

2017 
Capa: Mamangava Bombus morio visitando flor de Tibouchina granulosa. Foto tirada em Ubatuba, SP, Brasil. Arquivo original criado em 8 de fevereiro de 2014 na plataforma do Wikimedia Commons pelo usuário Leonardorejorge. Disponível em:

$<$ https://en.wikipedia.org/wiki/Bombus_morio\#/media/File:Bombus_morio_Tibouchina_granulosa.jpg $>$; Acesso em 30 set. 2017. 
Paulo Cseri Ricardo

Heteroplasmia em Bombus morio

(Hymenoptera, Apidae) e impactos em estudos evolutivos

Heteroplasmy in Bombus morio (Hymenoptera, Apidae) and impacts in evolutionary studies 


\section{Paulo Cseri Ricardo}

\section{Heteroplasmia em Bombus morio}

\section{(Hymenoptera, Apidae) e impactos em estudos evolutivos}

Heteroplasmy in Bombus morio (Hymenoptera, Apidae) and impacts in evolutionary studies

Dissertação apresentada ao Instituto de Biociências da Universidade de São Paulo, para a obtenção de Título de Mestre em Ciências, na Área de Biologia/Genética.

Orientadora: Dra. Maria Cristina Arias

São Paulo 


\section{Ficha Catalográfica}

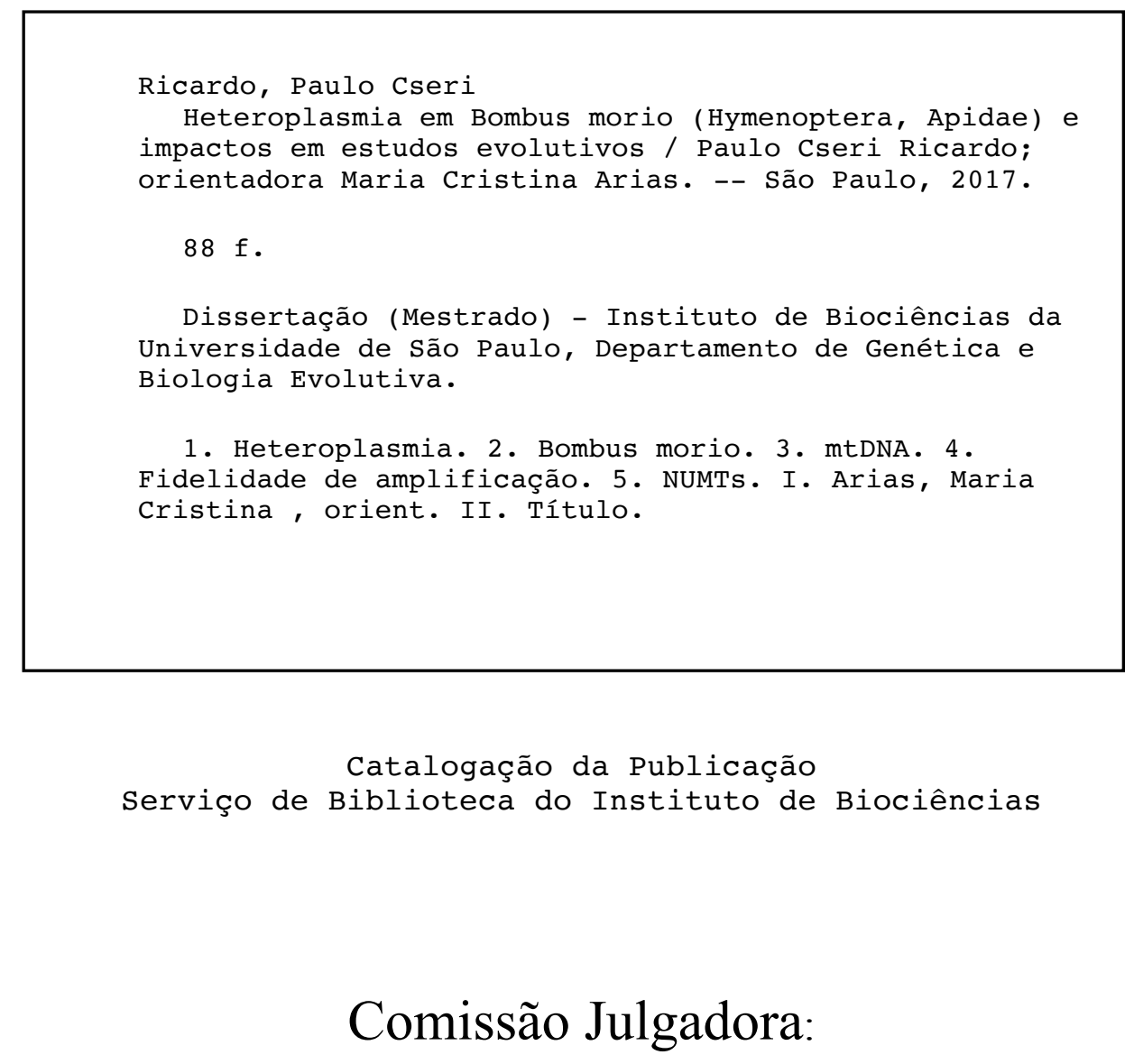

$\operatorname{Dr}(\mathrm{a})$.

$\operatorname{Dr}(\mathrm{a})$.

Dra. Maria Cristina Arias

Orientadora 
A todos que acreditaram e me apoiaram durante essa etapa de minha jornada. 
"O sucesso nasce do querer, da determinação e persistência em se chegar a um objetivo. Mesmo não atingindo $\mathrm{o}$ alvo, quem busca $\mathrm{e}$ vence obstáculos, no mínimo fará coisas admiráveis."

José de Alencar 


\section{Agradecimentos}

Agradeço primeiramente à Cris, a quem eu tenho como exemplo do ponto de vista profissional e pessoal, por ter me aceitado como orientando e ter me dado apoio em todos os aspectos possíveis durante a realização desse mestrado.

À Elaine, por quem alimento grande admiração como pesquisadora e foi a idealizadora desse trabalho, por tudo que me ensinou e por toda ajuda que sempre ofereceu.

À Priscila, maior companhia no dia a dia do laboratório, com quem dividi vários momentos, fossem eles de alegria, tristeza, discussões científicas e sobre assuntos diversos, ou apenas momentos, que ajudaram a construir uma amizade.

À Natália que sempre mostrou o lado positivo de cada situação, seja discutindo possibilidades na resolução de problemas, sendo trazendo alegria durante as conversas nos momentos de descontração.

À Susy, por quem tenho muito carinho, e que sempre me ajudou em tudo que pode no laboratório, inclusive suprindo minhas necessidades energéticas para prosseguir com o trabalho.

A todos que frequentaram o LGEA durante o tempo em que estive por aqui, sejam pertencentes ao LGEA ou agregados, que contribuíram, cada um à sua maneira, para que esse fosse um ótimo ambiente de trabalho. Em especial: Alexandre, Gláucia, Larissa Cont, Larissa Logullo, Natália Leite, Sheina, Thiago e Ulysses.

À minha família por todo o suporte para o meu desenvolvimento que foi oferecido durante toda a minha vida, sendo financeiro ou emocional, sempre acreditando no meu potencial.

Aos integrantes da antiga "casita" que me receberam como integrante, em especial ao André e a Bruna, que após o fim da "casita" me convidaram para morar com eles e me deram enorme ajuda em momentos de necessidade.

À Nathalie a pessoa que me apoiou incondicionalmente, me motivou, e sofreu tendo que ouvir meus desabafos durante todo esse tempo, mas sempre proporcionou alegria e amor, principalmente nos momentos em que mais precisei, me dando aporte emocional para superar mais uma fase de minha formação.

Aos “filogeneticamente próximos", meus grandes amigos de graduação que, mesmo não estando presentes fisicamente no dia a dia, sempre estiveram presentes em espírito mandando boas energias quando precisei.

Por fim, agradeço às agências CAPES, pela bolsa de mestrado, e FAPESP, pelo suporte financeiro para a realização desta pesquisa (processos 2013/12530-4 e 2016/24669-5). 


\section{Sumário}

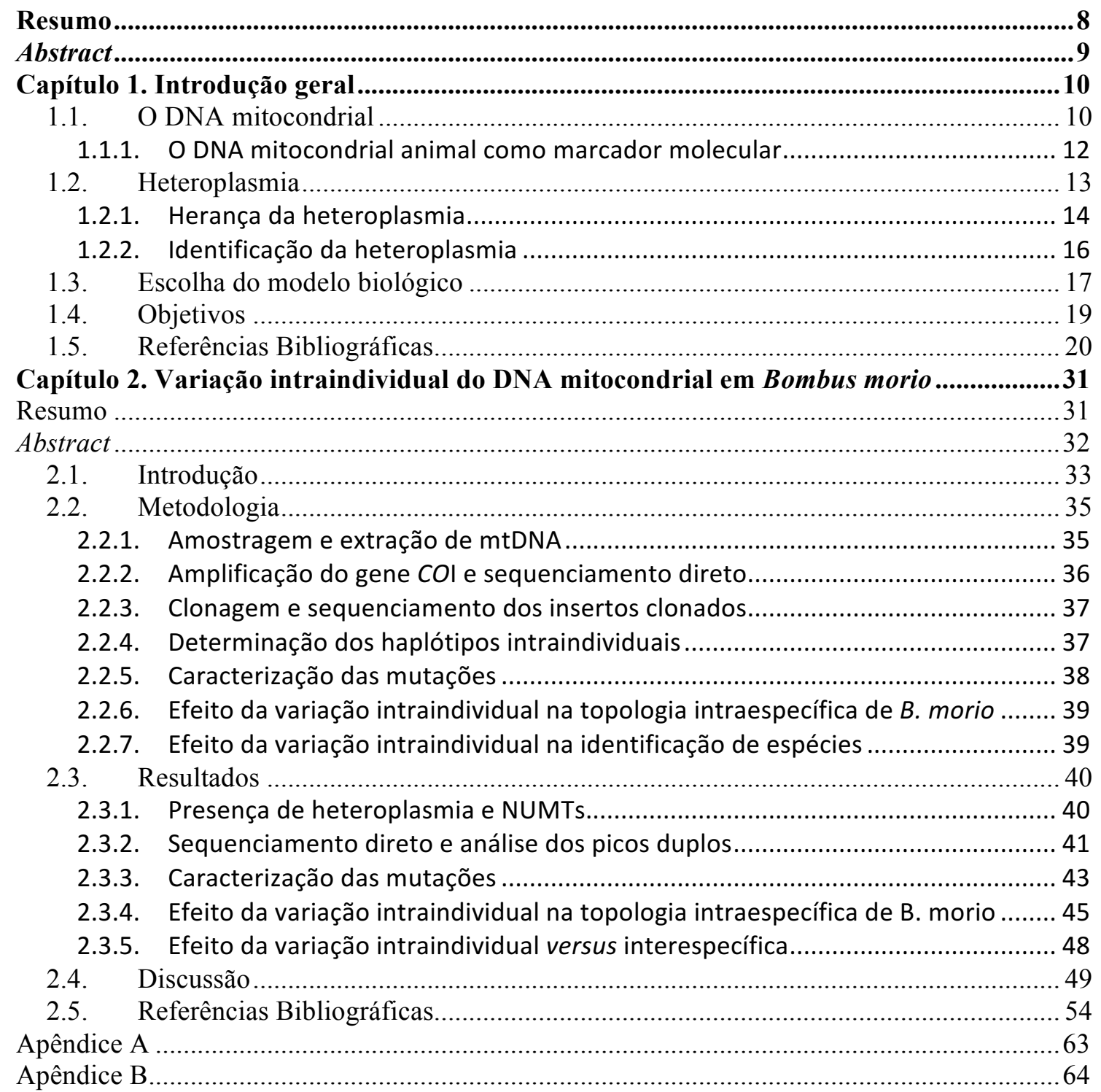

Capítulo 3. Fidelidade de amplificação de DNA por enzimas DNA polimerase e detecção de variação intraindividual do DNA mitocondrial .....................................................................72

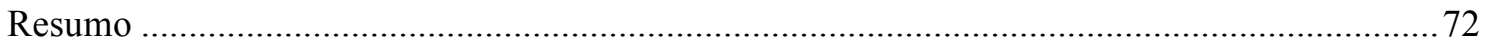

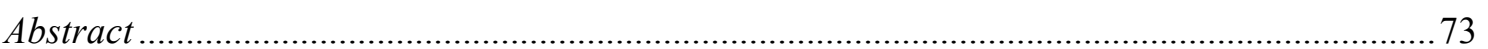

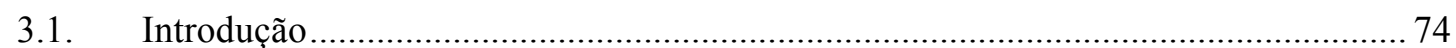

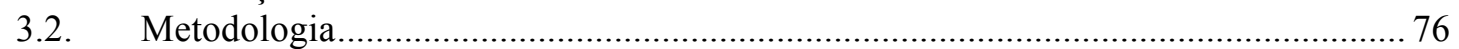

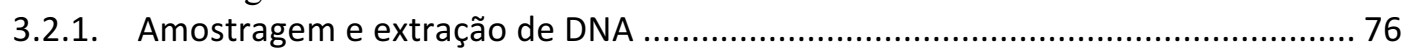

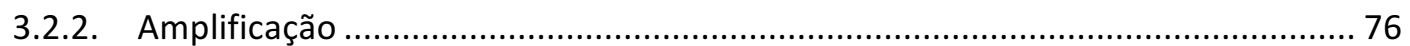

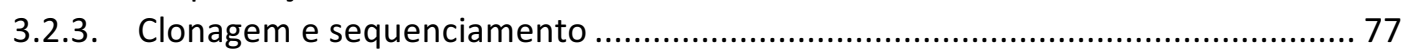

3.2.4. Quantificação número de haplótipos por indivíduo ..............................................77

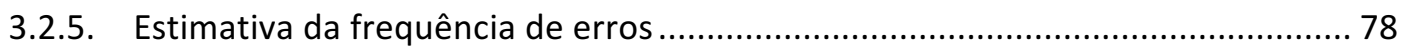

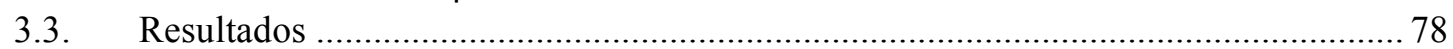

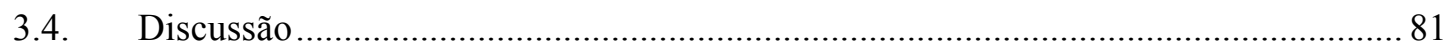

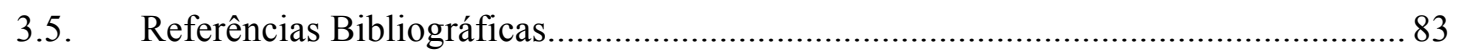

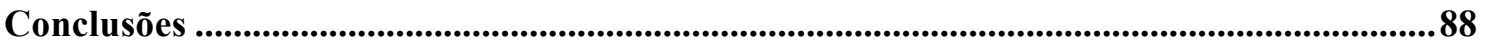




\section{Resumo}

A utilização de sequências do DNA mitocondrial (mtDNA) como marcadores moleculares na investigação da diversidade genética e evolução é muito difundida, auxiliando na realização de inferências em inúmeros trabalhos. Apesar de sua inegável importância, a utilização dessas sequências como marcadores moleculares suscita algumas questões. A heteroplasmia, por exemplo, é reconhecida como um desafio na utilização de sequências do mtDNA. Este estado ocorre quando um organismo apresenta diferentes haplótipos mitocondriais. Em um trabalho anterior, foram encontrados indícios que sugeriam a presença de heteroplasmia na espécie de abelha Bombus morio. O trabalho atual investigou de forma mais detalhada a presença de heteroplasmia nessa espécie, assim como fatores que podem influenciar na identificação desse estado. Os resultados obtidos confirmaram a existência de heteroplasmia nessa espécie, e identificaram que alguns haplótipos heteroplásmicos foram compartilhados entre indivíduos de localidades distintas. Esses haplótipos heteroplásmicos compartilhados sugerem a existência de heteroplasmia estável em B. morio, o que pode influenciar inferências evolutivas, e em especial, os estudos populacionais. Também foi detectada a presença de NUMTs, pseudogenes nucleares resultantes da transferência de sequências do mtDNA para o genoma nuclear. Esses NUMTs apresentaram grande divergência de sequência em relação aos haplótipos mitocondriais, o que poderia afetar análises filogenéticas e populacionais, além da identificação de espécies por meio do DNA barcoding. Ainda, erros de amplificação podem ser falsamente interpretados como variação intraindividual do DNA mitocondrial (mtDNA), superestimando o número de haplótipos, principalmente quando polimerases de baixa fidelidade são utilizadas. Por fim, os resultados observados neste trabalho sugerem que a utilização de sequências do mtDNA deve ser utilizada de forma cautelosa, e indícios de heteroplasmia, como a presença de picos duplos, não devem ser ignorados. Quando essas evidências são observadas investigações mais detalhadas devem ser aplicadas, a fim de aferir qual a sua origem, e, no caso da heteroplasmia ser confirmada, quais as possíveis consequências produzidas pela presença desse estado. 


\section{Abstract}

The mitochondrial DNA sequences (mtDNA) have been widely applied as molecular markers in the investigation of genetic diversity and evolution. Despite its undeniable importance, the use of these sequences as molecular markers may present some drawbacks. Heteroplasmy, for example, is recognized as a challenge. This state occurs when an individual has different mitochondrial haplotypes. In a previous work, evidences suggesting the presence of heteroplasmy in the bumblebee Bombus morio were verified. The present work investigated in more detail the presence of heteroplasmy in this species, as well as factors that may influence the identification of this state. The results confirmed the existence of heteroplasmy in this species, and identified that some heteroplasmic haplotypes were shared between individuals from different locations. These shared heteroplasmic haplotypes suggest the existence of stable heteroplasmy in B. morio, which may interfere in evolutionary inferences, especially in population studies. NUMTs, nuclear pseudogenes resulting from the transfer of mtDNA sequences to the nuclear genome, were also detected. These NUMTs showed great sequence divergence from mitochondrial haplotypes, which could affect phylogenetic and population analyzes, as well as species identification through DNA barcoding. In addition, it was observed that amplification errors might be misinterpreted as mtDNA intraindividual variation and overestimates the number of intraindividual haplotypes, especially when low fidelity polymerases are used. Finally, the results observed in this study suggest that the use of mtDNA sequences should be used carefully, and evidences of heteroplasmy, such as the presence of double peaks, should not be ignored. Additional investigations should be applied in case of heteroplasmy evidences to ascertain your source and the consequences of the presence of this state. 


\section{Capítulo 1 \\ Introdução geral}

\subsection{O DNA mitocondrial}

A mitocôndria é uma organela presente em todos os eucariotos, sendo a principal responsável por sustentar as necessidades energéticas das células, através do processo da fosforilação oxidativa (BOORE, 1999; CHAN, 2006; DOWLING, 2014). Nesse processo, o ATP é produzido a partir da energia gerada da oxidação de substratos metabólicos, tais como carboidratos e lipídeos (HANSFORD, 2002), em uma via que envolve cinco complexos proteicos presentes na membrana mitocondrial interna (HATEFI, 1985; BOEKEMA; BRAUN, 2007). Esses complexos possuem algumas de suas subunidades estruturais codificadas pelo genoma da mitocôndria, que é um genoma exclusivo, geralmente circular, com características muito similares a genomas de bactérias aeróbicas, especialmente as do grupo das $\alpha$ Proteobactérias (GRAY, 1999). As mitocôndrias apresentam um sistema independente de transcrição e tradução de seus RNA mensageiros (mRNA), um código genético com alguns códons diferentes em relação ao nuclear, ribossomos exclusivos, e a capacidade de auto replicação, que permite com que se repliquem, e aumentem em número, independentemente da divisão celular (WALLACE, 1992, 2005). Essas particularidades dão suporte à teoria da endossimbiose, que sugere que a mitocôndria surgiu a partir da interação simbiótica entre uma célula eucariótica ancestral e uma $\alpha$-Proteobactéria (GRAY, 1999).

Acredita-se que após a ocorrência da endossimbiose, a maioria dos genes da mitocôndria, originalmente parte do genoma da $\alpha$-Proteobactéria, foi transferida e inserida no genoma nuclear, onde são replicados e transcritos. Esse processo resultou em uma diminuição considerável desse genoma durante sua evolução (WALLACE, 2005). Evidências dessa redução do genoma podem ser obtidas através da comparação entre organismos. O protista Reclinomonas americana, por exemplo, compartilha características estruturais do citoesqueleto com retortamonádos amitocondriados, um grupo de protozoários que provavelmente divergiu dos demais eucariotos antes da obtenção da mitocôndria (O'KELLY, 1993). Ao mesmo tempo, o R. americana apresenta uma molécula de DNA mitocondrial (mtDNA) com 69.034 pb e 94 genes, o maior número de genes encontrados em um genoma mitocondrial, incluindo genes que em outros eucariotos se encontram no DNA nuclear (nuDNA) (LANG et al., 1997; LANG; GRAY; BURGER, 1999). 
O tamanho médio do genoma mitocondrial animal é de $16 \mathrm{~Kb}$ (LIGHTOWLERS et al., 1997; ZHANG; HEWITT, 1997), e contém uma região não codificante, hipervariável, envolvida no controle da transcrição e replicação do mtDNA (SHADEL; CLAYTON, 1997), e poucos genes: 13 para proteínas envolvidas no transporte de elétrons e na síntese de ATP; 22 para RNA transportador (tRNA); e dois genes para as subunidades do RNA ribossômico (rRNA) (AVISE et al., 1987; MORITZ; DOWLING; BROWN, 1987). Cerca de 99\% das proteínas que atuam nas mitocôndrias dos animais são codificadas por genes situados no nuDNA (MEISINGER; SICKMANN; PFANNER, 2008).

As moléculas do mtDNA animal se encontram organizadas em arranjos denominados nucleoides mitocondriais (NASS, 1969), complexos proteína-DNA análogos ao cromossomo bacteriano (CHEN; BUTOW, 2005). Esses complexos apresentam proteínas envolvidas em sua própria manutenção, além de vários fatores de transcrição e replicação mitocondriais, todos codificados pelo nuDNA (KUCEJ; BUTOW, 2007). Uma mesma mitocôndria pode apresentar vários nucleoides, sendo que o número de cópias de mtDNA associadas a esses nucleoides é igualmente variável (SATOH; KUROIWA, 1991). Em humanos, por exemplo, foram reportadas de 2 a 8 moléculas de mtDNA por nucleoide (LEGROS, 2004). Dessa forma, em uma única célula podem existir milhares a centenas de milhares de moléculas de mtDNA, dependendo do tipo celular (WHITE et al., 2008).

Diferentemente do nuDNA, em grande parte dos eucariotos, a transmissão do mtDNA é uniparental (HAYASHI et al., 1978; GILES et al., 1980; CUMMINS, 2006), sendo que nos animais é a fêmea quem contribui com o material genético mitocondrial (HOEKSTRA, 2000), transmitido a partir do citoplasma do gameta feminino. O mtDNA paterno comumente é eliminado ativamente através de mecanismos moleculares e celulares, que podem divergir dependendo da espécie (KANEDA et al., 1995; SUTOVSKY et al., 2000; SATO; SATO, 2011; DELUCA; O'FARRELL, 2012).

Ainda não são claros os mecanismos evolutivos subjacentes à conservação do padrão de herança uniparental nos eucariotos, mas é provável que essa estratégia evite desvantagens promovidas pela presença de dois genótipos mitocondriais distintos, mesmo que equivalentes (MISHRA; CHAN, 2014). Sharpley et al. (2012) realizaram um estudo que fortalece essa hipótese. Nesse estudo foram produzidos camundongos com os genótipos mitocondriais $N Z B$, 129 e indivíduos $N Z B-129$. Os indivíduos $N Z B-129$ apresentaram alterações metabólicas e comportamentais negativas quando comparados aos demais (SHARPLEY et al., 2012). Além disso, é discutido que a eliminação do mtDNA paterno pode evitar mutações deletérias, uma 
vez que o mtDNA paterno provavelmente é fortemente danificado por radicais livres durante a espermatogênese e o nado em direção ao óvulo (SATO; SATO, 2013).

As taxas de mutação encontradas no mtDNA são tidas como altamente superiores às apresentadas por loci nucleares de genes de cópia única (BROWN; GEORGE; WILSON, 1979; LYNCH, 2006). Isso provavelmente está relacionado a fatores como: propriedades mutagênicas dos radicais livres de oxigênio produzidos no processo de fosforilação oxidativa (BALABAN; NEMOTO; FINKEL, 2005) e ao grande número de replicações, independentes da divisão celular, aliado a baixa fidelidade na replicação decorrente da baixa eficiência dos mecanismos de reparo (JOHNSON; JOHNSON, 2001; MASON; LIGHTOWLERS, 2003). Contudo, na ausência de seleção positiva, é esperado que apenas mutações neutras, ou pouco deletérias, se acumulem ao longo do tempo (GALTIER et al., 2009). Essas mutações normalmente ocorrem na terceira posição dos códons devido ao emparelhamento códon-anticódon nas mitocôndrias ser flexível, permitindo que uma mesma molécula de tRNA reconheça qualquer um dos quatro nucleotídeos na terceira posição do códon (ALBERTS et al., 2002).

\subsubsection{O DNA mitocondrial animal como marcador molecular}

O mtDNA tem sido, nas últimas décadas, o marcador mais amplamente utilizado em estudos que necessitam acessar a diversidade molecular em animais (GALTIER et al., 2009), tais como filogeografia (AVISE et al., 1987), genética da conservação (ROBERTSON et al., 2007), filogenia (KIVISILD et al., 2006) e identificação de espécies (HEBERT et al., 2003). Essa molécula apresenta várias propriedades favoráveis à sua utilização como marcador molecular, como tamanho reduzido e relativa abundância em relação ao genoma nuclear, o que facilita estratégias de extração e amplificação (SIMON et al., 1994). Outra característica é a ortologia dos seus genes, o que permite comparações homólogas. Ao mesmo tempo, as altas taxas de mutação mitocondriais possibilitam o surgimento de polimorfismos, que podem ser utilizados como sinais para distinção de linhagens (MORITZ; DOWLING; BROWN, 1987). Além disso, a herança materna (salvo algumas exceções) associada à ausência (ou baixos níveis) de recombinação, viabiliza a construção de genealogias dessas linhagens (AVISE et al., 1987; SUNNUCKS, 2000). Aliados a essas características, alguns fatores tecnológicos tiveram um papel importante no aumento da popularidade do mtDNA, principalmente durante a década de 1980 e a primeira metade dos anos 1990: o desenvolvimento de protocolos de isolamento de mtDNA; o uso de enzimas de restrição na detecção de polimorfismos; a otimização da técnica de PCR; e a utilização de primers universais (PATWARDHAN; RAY; ROY, 2014). No início 
dos anos 2000 a abordagem do DNA barcoding, proposta por Hebert et al. (2003) para a identificação taxonômica e investigação da biodiversidade, revigorou a discussão e a utilização do mtDNA como marcador (GALTIER et al., 2009).

Apesar da inegável conveniência da utilização de sequências do mtDNA como marcadores moleculares, algumas condições podem representar desafios em sua utilização. A presença de NUMTs (Nuclear mitocondrial pseudogenes), por exemplo, pode interferir nas análises em estudos evolutivos (ZHANG; HEWITT, 1996). Os NUMTs são sequências "fósseis" do mtDNA presentes no nuDNA (RICHLY; LEISTER, 2004), onde tendem a acumular mutações livremente (FREY; FREY, 2004). Outro problema associado com a utilização do mtDNA em estudos evolutivos é a presença de heteroplasmia.

\subsection{Heteroplasmia}

A heteroplasmia mitocondrial é um estado onde um mesmo indivíduo apresenta moléculas de mtDNA variantes (LIGHTOWLERS et al., 1997; HOWELL et al., 2000; KMIEC; WOLOSZYNSKA; JANSKA, 2006). A heteroplasmia pode ser de comprimento, quando as moléculas apresentam tamanhos distintos, ou pontual, na qual as diferenças ocorrem devido a substituições nucleotídicas (VOLLMER et al., 2011; DUDU et al., 2012).

Os primeiros trabalhos descrevendo heteroplasmia em animais surgiram no início da década de 1980 (HAUSWIRTH; LAIPIS, 1982; GREENBERG; NEWBOLD; SUGINO, 1983; SOLIGNAC; MONNEROT; MOUNOLOU, 1983). Esses trabalhos encontraram variações de comprimento do mtDNA, após a digestão da região controle com enzimas de restrição. Em 1987 Boursot et al. relataram pela primeira vez uma heteroplasmia relacionada a regiões codificantes. Ela consistia em uma deleção de $5 \mathrm{~Kb}$ compreendendo seis genes para tRNA e sete para proteínas. Durante os anos que se seguiram, a heteroplasmia foi alvo de diversos estudos, especialmente em humanos, uma vez que a relação entre a presença de heteroplasmia e patologias foi constatada (HOLT; HARDING; MORGAN-HUGHES, 1988; HOLT; MILLER; HARDING, 1989; MORAES et al., 1989; RÖTIG et al., 1990).

Até o momento, mais de 650 mutações no mtDNA estão relacionadas a patologias humanas, sendo que a maior parte delas ocorre devido à heteroplasmias pontuais (MITOMAP: a human mitochondrial genome database, 2017). No entanto, a heteroplasmia não está necessariamente associada a condições patológicas, e foi encontrada em indivíduos saudáveis (COMAS; PÄÄBO; BERTRANPETIT, 1995; JAZIN et al., 1996; BENDALL; MACAULAY; SYKES, 1997; KIRCHES et al., 2001; IRWIN et al., 2009). Acredita-se que a heteroplasmia 
apresente um papel importante no envelhecimento (GONZALEZ-FREIRE et al., 2015). Sondheimer et al. (2011) constataram correlação positiva entre a quantidade média de heteroplasmia e a idade, incluindo substituições sinônimas em regiões codificantes.

A heteroplasmia em células somáticas, mesmo que em níveis baixos, é bem documentada em humanos (SATOH; KUROIWA, 1991; PAYNE et al., 2013), mas também foi descrita em animais de diversos grupos. Entre os vertebrados existem registros em diferentes espécies de peixes (BROWN; BECKENBACH; SMITH, 1992; NESBØ; ARAB; JAKOBSEN, 1998; HOARAU et al., 2002; WOLFF et al., 2011), anfíbios (BERMINGHAM; LAMB; AVISE, 1986; RADOJIČIĆ et al., 2015), mamíferos (HAUSWIRTH; LAIPIS, 1982; BOURSOT; YONEKAWA; BONHOMME, 1987; WILKINSON; CHAPMAN, 1991; SAVOLAINEN; ARVESTAD; LUNDEBERG, 2000; MATÉ et al., 2007; MCLEOD; WHITE, 2010), répteis escamados (DENSMORE; WRIGHT; BROWN, 1985; KUMAZAWA, 2004) e aves (BERG; MOUM; JOHANSEN, 1995; MUNDY; WINCHELL; WOODRUFF, 1996; CROCHET; DESMARAIS, 2000; MOUM; BAKKE, 2001; KVIST et al., 2003). Em invertebrados a heteroplasmia já foi encontrada em moluscos (ZOUROS et al., 1994), nematódeos (TSANG; LEMIRE, 2002), crustáceos (DOUBLET et al., 2008; LINDHOLM et al., 2016), colêmbolos (NARDI et al., 2001), e em insetos como percevejos (ROBISON et al., 2015), mariposas (MARGARITOPOULOS et al., 2007), moscas (SOLIGNAC; MONNEROT; MOUNOLOU, 1983; VOLZ-LINGENHOHL; SOLIGNAC; SPERLICH, 1992), besouros (BOYCE; ZWICK; AQUADRO, 1989; AZEREDO-ESPIN et al., 1996), gafanhotos (KANG et al., 2015) e abelhas (MAGNACCA; DANFORTH, 2006; SONGRAM; SITTIPRANEED; KLINBUNGA, 2006). Esses dados indicam que a heteroplasmia provavelmente é um estado mais frequente do que se supõe.

\subsubsection{Herança da heteroplasmia}

A principal hipótese em relação à herança da heteroplasmia é a do gargalo mitocondrial (STEWART; CHINNERY, 2015). Segundo essa hipótese a homoplasia é restaurada em poucas gerações, com a fixação de uma das variantes de mtDNA (SHOUBRIDGE, 2000). Isso ocorreria devido ao evento de gargalo na população de mitocôndrias durante o início da embriogênese, seguido de um grande aumento ao longo da oogênese (JANSEN; DE BOER, 1998). Na embriogênese, durante os estágios iniciais de clivagem do embrião a duplicação das mitocôndrias raramente é observada (SATHANANTHAN; TROUNSON, 2000), e aparentemente a replicação do mtDNA só é 
retomada ao final do estágio de blastocisto (THUNDATHIL; FILION; SMITH, 2005). A partilha das mitocôndrias ocorre de forma equivalente entre as células filhas ao longo das clivagens celulares, levando a uma diminuição na ordem de 10.000 vezes no número de mitocôndrias presentes em cada célula (SHOUBRIDGE; WAI, 2007). Na oogênese, as células germinativas primordiais, que contêm um número reduzido de mitocôndrias (10 a 100 em humanos; (SHOUBRIDGE; WAI, 2007), se diferenciam em oogônias, e posteriormente em oócitos primários, que experimentam um grande aumento no número de mitocôndrias (WHITE et al., 2008). A maturação dos oócitos só ocorre na fase adulta, e nessa fase há um grande aumento no número de moléculas de mtDNA (JANSEN; DE BOER, 1998). A amplificação do mtDNA baseada nas poucas cópias disponíveis após o gargalo resulta na herança de apenas uma pequena proporção de variantes de mtDNA pelos descendentes, levando à fixação ou perda dessas variantes rapidamente (CHINNERY et al., 2000). Essa hipótese foi sugerida pela primeira vez por Hauswirth e Laipis (1982) e posteriormente sustentada por resultados obtidos em outros estudos com mamíferos (ASHLEY; LAIPIS; HAUSWIRTH, 1989; KOEHLER et al., 1991; HOWELL et al., 1992; JENUTH et al., 1996).

Contrariando a hipótese do gargalo mitocondrial, existem relatos da manutenção da heteroplasmia ao longo de várias gerações. No trabalho de Volz-Lingenhöhl et al. (1992), ao longo de 70 gerações analisadas, todos os indivíduos de Drosophila subobscura amostrados apresentaram uma heteroplasmia envolvendo uma deleção que afetava seis genes para proteínas e quatro para tRNA. Em um trabalho com o nematódeo Caenorhabditis elegans, Tsang e Lemire (2002) também identificaram a ocorrência de heteroplasmia estável. Durante as 100 gerações estudadas foi identificada a co-existência de moléculas do tipo selvagem e moléculas com a mutação $u a D f 5$, que consiste em uma deleção envolvendo quatro genes codificantes de proteínas e sete de tRNA (TSANG; LEMIRE, 2002). Doublet et al. (2008) estudando a espécie Armadillidium vulgare, um isópode terrestre pertencente a subordem Oniscidae, encontraram uma heteroplasmia pontual que ocorre devido ao polimorfismo em um gene para tRNA. Em uma comparação com outras 20 espécies da subordem Oniscidae, 16 também apresentaram essa heteroplasmia, compreendendo 10 famílias distintas. Diante desses resultados foi sugerido que, entre os oniscídeos, essa heteroplasmia é herdada de forma estável há pelo menos 30 milhões de anos (DOUBLET et al., 2008).

O modelo faithful nucleoid (JACOBS; LEHTINEN; SPELBRINK, 2000) oferece uma explicação para a transmissão estável da heteroplasmia. Esse modelo propõe que os nucleoides mitocondriais possam conter diferentes tipos de moléculas de mtDNA, e que esses nucleoides 
são replicados fielmente a cada divisão, mantendo seu conteúdo genético. Isso permite a transmissão estável de uma heteroplasmia por várias gerações, mesmo em casos de mutações deletérias, desde que os nucleoides retenham uma cópia funcional de cada gene (JACOBS; LEHTINEN; SPELBRINK, 2000).

A heteroplasmia também pode ser resultado de herança biparental. Embora normalmente a herança do mtDNA nos animais seja materna, existem estudos que relatam a herança biparental em algumas espécies (GYLLENSTEN et al., 1991; KONDO; MATSUURA; CHIGUSA, 1992; ZOUROS et al., 1994; KVIST et al., 2003; ZHAO et al., 2004; FONTAINE; COOLEY; SIMON, 2007). No entanto, com exceção de alguns grupos de moluscos bivalves, essa herança aparentemente é acidental, não envolvendo mecanismos estáveis de transmissão biparental do mtDNA (ZOUROS, 2013). O mais provável é que a herança biparental do mtDNA esteja ligada a disfunções nos oócitos (ST. JOHN; COOKE; BARRATT, 1997). Essas disfunções resultariam em falha na eliminação do mtDNA paterno, permitindo o paternal leakage, onde o mtDNA paterno seria mantido durante o desenvolvimento do embrião (ST. JOHN et al., 2000). O mesmo conceito se aplica em cruzamentos entre duas espécies diferentes, uma vez que os mecanismos de eliminação do mtDNA paterno podem ser divergentes entre as espécies (ROKAS; LADOUKAKIS; ZOUROS, 2003).

\subsubsection{Identificação da heteroplasmia}

A presença de heteroplasmia pode ser detectada através de diferentes métodos. A análise da digestão de regiões do mtDNA por enzimas de restrição pode ser utilizada para a identificação da variação intraindividual do mtDNA (HAUSWIRTH; LAIPIS, 1982; BENTZEN; LEGGETT; BROWN, 1988; FREY; FREY, 2004). No entanto, esse método é mais eficiente na identificação de heteroplasmia de comprimento, sendo que mutações pontuais são detectadas apenas quando ocorrem em sítios de restrição (JUVONEN et al., 1994).

Métodos que envolvem o sequenciamento de DNA também possibilitam a identificação da heteroplasmia. Dentre esses métodos, a observação de picos duplos em eletroferogramas é o mais simples. Nos eletroferogramas, picos duplos isolados sugerem a presença de heteroplasmia pontual, enquanto que heteroplasmias de comprimento seriam visualizadas como uma série de picos duplos ao longo do eletroferograma, iniciados a partir do sítio onde o indel ocorreu (VOLLMER et al., 2011). No entanto, variantes muito raras podem não ser detectadas em um sequenciamento direto devido a sua baixa frequência (LIN et al., 
2002). Além disso, picos duplos também podem ser resultantes de artefatos de amplificação ou contaminação por DNA exógeno.

A clonagem de produtos de PCR permite isolar variantes heteroplásmicas (BUHAY, 2009), e recuperar mesmo haplótipos heteroplásmicos pouco frequentes. O sequenciamento desses produtos clonados possibilita a análise direta das sequências dos haplótipos, o que torna esse método muito interessante na investigação da heteroplasmia. Contudo, essa técnica também é suscetível a recuperar sequências com erros de amplificação (MCINERNEY; ADAMS; HADI, 2014), que podem ser confundidas com sequências heteroplásmicas. Esses erros estão ligados à fidelidade da DNA polimerase utilizada, pois quanto maior a fidelidade da enzima, menor a quantidade de erros produzidos (KUNKEL; BEBENEK, 2000). No entanto, mesmo enzimas de alta fidelidade podem apresentar erros na incorporação de nucleotídeos. Assim, a detecção e exclusão desses artefatos é importante para evitar a presença de falsos positivos na identificação de heteroplasmia (NAUE et al., 2015).

Nos últimos anos, metodologias utilizando sequenciamento em larga escala (high throughput sequencing) vêm sendo desenvolvidas e utilizadas para a identificação da heteroplasmia (GUO et al., 2013; YE et al., 2014; ALBAYRAK et al., 2016). Com o avanço e redução do custo dessas metodologias, em um futuro próximo elas poderão representar alternativas interessantes aos métodos tradicionalmente utilizados.

\subsection{Escolha do modelo biológico}

Este trabalho tem como objetivo o estudo da heteroplasmia na espécie Bombus morio Swederus (1787). As espécies do gênero Bombus são importantes polinizadores (GARRATT et al., 2014) principalmente em regiões frias e temperadas (GOULSON; LYE; DARVILL, 2008). Esse gênero é constituído por aproximadamente 260 espécies (WILLIAMS, 2017), sendo que a maioria ocorre na região Paleártica (WILLIAMS et al., 2008). No Brasil, até o momento, além de B. morio, foram descritas apenas outras 7 espécies desse gênero: Bombus applanatus Oliveira, Françoso \& Arias (2016), Bombus bahiensis Santos Júnior \& Silveira (2015), Bombus bellicosus Smith (1879), Bombus brasiliensis Lepelitier (1836), Bombus brevivillus Franklin (1913), Bombus pauloensis Friese (1913), Bombus transversalis Olivier (1789). Todas as espécies brasileiras pertencem ao subgênero Thoracobombus (WILLIAMS, 2017). No entanto, B. morio apresenta características moleculares que a distingue das demais espécies brasileiras, sendo mais próxima filogeneticamente das espécies Bombus dahlbomii Guérin-Menéville (1835) e Bombus excellens Smith (1879) (CAMERON; HINES; 
WILLIAMS, 2007), cujas distribuições não abrangem o território brasileiro (ABRAHAMOVICH; DÍAZ; MORRONE, 2004). A distribuição de B. morio compreende grande parte do território nacional, existindo registros de sua presença nos estados da Bahia, Goiás, Mato Grosso, Mato Grosso do Sul, e em toda a região Sudeste e Sul (MOURE; MELO, 2012; FRANÇOSO et al., 2016).

Françoso et al. (2016) identificaram a ocorrência de picos duplos nos eletroferogramas de alguns espécimes de $B$. morio, o que foi atribuído à presença de heteroplasmia. Além disso, vários desses picos duplos foram observados no mesmo sítio em indivíduos diferentes (Figura 1.1). Embora Françoso et al. (2016) tenham se preocupado em separar e analisar o efeito de possíveis haplótipos heteroplásmicos nos indivíduos que apresentaram picos duplos, a metodologia empregada foi desenvolvida para loci nucleares, trabalhando exclusivamente com genótipos diploides (FLOT, 2010). Como os indivíduos com heteroplasmia podem ser poliploides para o mtDNA, uma investigação mais aprofundada fez-se necessária, a fim de avaliar os reais impactos causados por esse estado.

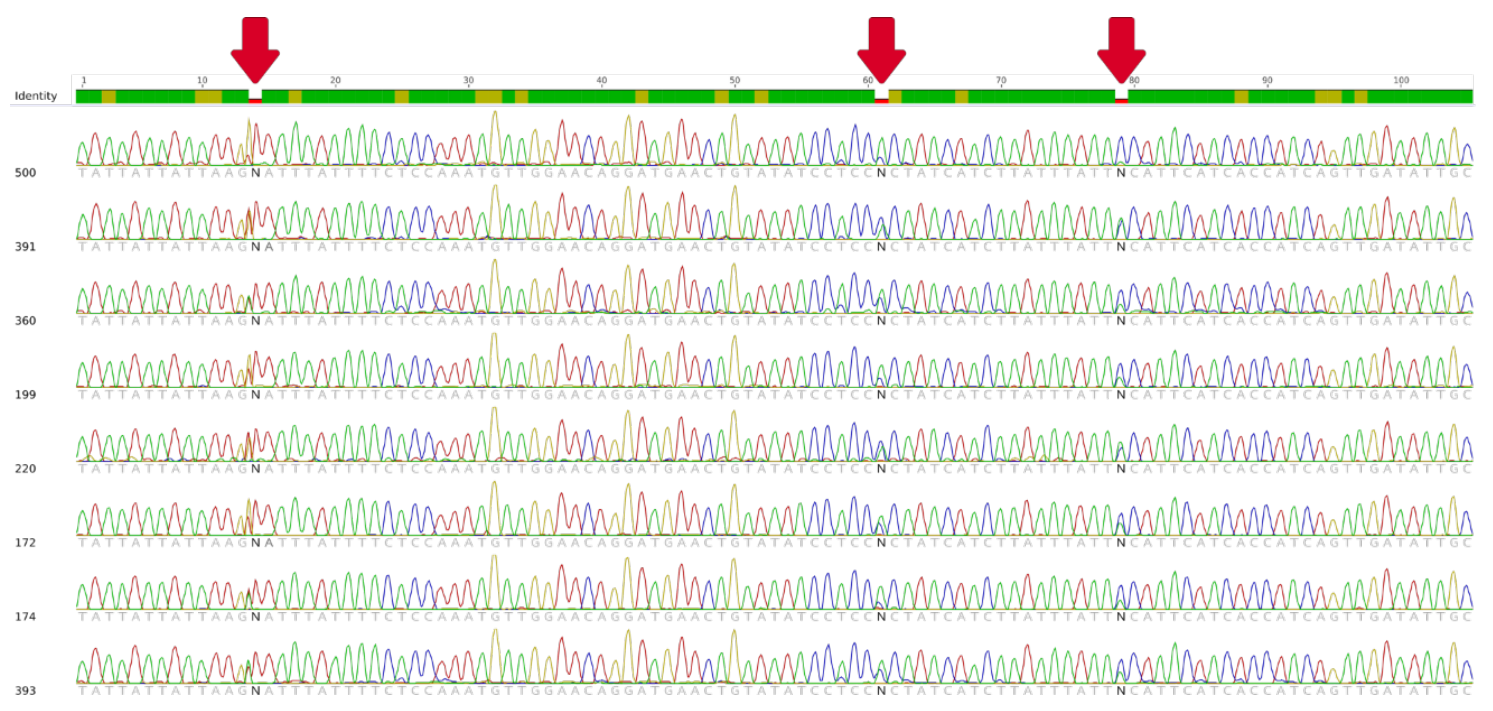

Figura 1.1. Alinhamento exibindo os picos duplos observados por Françoso et al. (2016). Os sítios com picos duplos estão identificados pela letra $\mathrm{N}$ e indicados pelas setas vermelhas. 


\subsection{Objetivos}

Os objetivos desse projeto de mestrado foram:

a) Testar a hipótese de que a heteroplasmia em B. morio é um estado conservado. Resultados anteriores, obtidos por nosso grupo de pesquisa, sugeriram que a heteroplasmia em B. morio fosse estável, pois indivíduos de localidades distintas apresentaram picos duplos nos mesmos sítios, indicando compartilhamento de haplótipos heteroplásmicos;

b) Testar a hipótese de que o uso de sequências de mtDNA como marcadores moleculares para organismos que possuem heteroplasmia pode enviesar estudos evolutivos. A predição é que a presença de vários haplótipos em um mesmo indivíduo torna a leitura das sequências ambígua, e influencia na construção de redes de haplótipos e topologias, possibilitando inferências equivocadas.

c) Testar a hipótese de que há erros durante a amplificação por PCR, e que estes podem influenciar a quantificação de haplótipos intraindividuais. 


\subsection{Referências Bibliográficas}

ABRAHAMOVICH, A. H.; DÍAZ, N. B.; MORRONE, J. J. Distributional patterns of the neotropical and andean species of the genus Bombus (Hymenoptera: Apidae). Acta Zoológica Mexicana, v. 20, n. 1, p. 99-117, 2004.

ALBAYRAK, L.; KHANIPOV, K.; PIMENOVA, M.; GOLOVKO, G.; ROJAS, M.; PAVLIDIS, I.; CHUMAKOV, S.; AGUILAR, G.; CHÁVEZ, A.; WIDGER, W. R.; FOFANOV, Y. The ability of human nuclear DNA to cause false positive low-abundance heteroplasmy calls varies across the mitochondrial genome. BMC Genomics, v. 17, n. 1, p. 1017, 2016.

ALBERTS, B.; JOHNSON, A.; LEWIS, J.; RAFF, M.; ROBERTS, K.; WALTER, P. Energy conversion: mitochondria and chloroplasts. In: Molecular Biology of the Cell. New York: Garland Science, 2002. p. 767-829.

ASHLEY, M. V.; LAIPIS, P. J.; HAUSWIRTH, W. W. Rapid segregation of heteroplasmic bovine mitocondria. Nucleic Acids Research, v. 17, n. 18, p. 7325-7331, 1989.

AVISE, J. C.; ARNOLD, J.; BALL, R. M.; CAROL, A. Intraspecific Phylogeography: the mitocondrial DNA bridge between population genetics and systematics. Annual Review of Ecology and Systematics, v. 18, p. 489-522, 1987.

AZEREDO-ESPIN, A. M. L.; SCHRODER, R. F. W.; RODERICK, G. K.; SHEPPARD, W. S. Intraspecific mitochondrial DNA variation in the Colorado potato beetle, Leptinotarsa decemlineata (Coleoptera: Chrysomelidae). Biochemical Genetics, v. 34, n. 7-8, p. 253-268, 1996.

BALABAN, R. S.; NEMOTO, S.; FINKEL, T. Mitochondria, oxidants, and aging. Cell, v. 120, n. 4, p. 483-495, 2005.

BENDALL, K. E.; MACAULAY, V. A.; SYKES, B. C. Variable levels of a heteroplasmic point mutation in individual hair roots. The American Journal of Human Genetics, v. 61, n. 6, p. 1303-1308, 1997.

BENTZEN, P.; LEGGETT, W. C.; BROWN, G. G. Length and restriction site heteroplasmy in the mitochondrial DNA of american shad (Alosa sapidissima). Genetics, v. 118, n. 3, p. 509$518,1988$.

BERG, T.; MOUM, T.; JOHANSEN, S. Variable numbers of simple tandem repeats make birds of the order Ciconiiformes heteroplasmic in their mitochondrial genomes. Current Genetics, v. 27, n. 3, p. 257-262, 1995.

BERMINGHAM, E.; LAMB, T.; AVISE, J. C. Size polymorphism and heteroplasmy in the mitochondrial DNA of lower vertebrates. Journal of Heredity, v. 77, n. 4, p. 249-252, 1986.

BOEKEMA, E. J.; BRAUN, H.-P. Supramolecular structure of the mitochondrial oxidative phosphorylation system. Journal of Biological Chemistry, v. 282, n. 1, p. 1-4, 2007. 
BOORE, J. L. Animal mitochondrial genomes. Nucleic Acids Research, v. 27, n. 8, p. 17671780, 1999.

BOURSOT, P.; YONEKAWA, H.; BONHOMME, F. Heteroplasmy in mice with deletion of a large coding region of mitochondrial DNA. Molecular Biology and Evolution, v. 4, n. 1, p. 46-55, 1987.

BOYCE, T. M.; ZWICK, M. E.; AQUADRO, C. F. Mitochondrial DNA in the bark weevils: size, structure and heteroplasmy. Genetics, v. 123, n. 4, p. 825-836, 1989.

BROWN, J. R.; BECKENBACH, A. T.; SMITH, M. J. Mitochondrial DNA length variation and heteroplasmy in populations of white sturgeon (Acipenser transmontanus). Genetics, v. 132, n. 1, p. 221-228, 1992.

BROWN, W. M.; GEORGE, M.; WILSON, A. C. Rapid evolution of animal mitochondrial DNA. Proceedings of the National Academy of Sciences, v. 76, n. 4, p. 1967-1979, 1979.

BUHAY, J. E. "COI-like" sequences are becoming problematic in molecular systematic and DNA barcoding studies. Journal of Crustacean Biology, v. 29, n. 1, p. 96-110, 2009.

CAMERON, S. A.; HINES, H. M.; WILLIAMS, P. H. A comprehensive phylogeny of the bumble bees (Bombus). Biological Journal of the Linnean Society, v. 91, n. 1, p. 161-188, 2007.

CHAN, D. C. Mitochondria: dynamic organelles in disease, aging, and development. Cell, v. 125, n. 7, p. 1241-1252, 2006.

CHEN, X. J.; BUTOW, R. A. The organization and inheritance of the mitochondrial genome. Nature Reviews Genetics, v. 6, n. 11, p. 815-825, 2005.

CHINNERY, P. F.; THORBURN, D. R.; SAMUELS, D. C.; WHITE, S. L.; DAHL, H.-H. M.; TURNBULL, D. M.; LIGHTOWLERS, R. N.; HOWELL, N. The inheritance of mitochondrial DNA heteroplasmy: random drift, selection or both? Trends in Genetics, v. 16, n. 11, p. 500$505,2000$.

COMAS, D.; PÄÄBO, S.; BERTRANPETIT, J. Heteroplasmy in the control region of human mitochondrial DNA. Genome Research, v. 5, n. 1, p. 89-90, 1995.

CROCHET, P.-A.; DESMARAIS, E. Slow rate of evolution in the mitochondrial control region of gulls (Aves: Laridae). Molecular Biology and Evolution, v. 17, n. 12, p. 1797-1806, 2000.

CUMMINS, J. Mitochondrial DNA: fate of the paternal mitochondrial genome. In: Encyclopedia of Life Sciences. Chichester, UK: John Wiley \& Sons, Ltd, 2006. p. 4541-4550.

DELUCA, S. Z.; O'FARRELL, P. H. Barriers to male transmission of mitochondrial DNA in sperm development. Developmental Cell, v. 22, n. 3, p. 660-668, 2012.

DENSMORE, L. D.; WRIGHT, J. W.; BROWN, W. M. Length variation and heteroplasmy are frequent in mitochondrial DNA from parthenogenetic and bisexual lizards (genus 
Cnemidophorus). Genetics, v. 110, n. 4, p. 689-707, 1985.

DOUBLET, V.; SOUTY-GROSSET, C.; BOUCHON, D.; CORDAUX, R.; MARCADÉ, I. A thirty million year-old inherited heteroplasmy. PLoS ONE, v. 3, n. 8, p. e2938, 2008. doi: 10.1371/journal.pone.0002938

DOWLING, D. K. Evolutionary perspectives on the links between mitochondrial genotype and disease phenotype. Biochimica et Biophysica Acta, v. 1840, n. 4, p. 1393-1403, 2014.

DUDU, A.; GEORGESCU, S. E.; BERREBI, P.; COSTACHE, M. Site heteroplasmy in the mitochondrial cytochrome $\mathrm{b}$ gene of the sterlet sturgeon Acipenser ruthenus. Genetics and Molecular Biology, v. 35, n. 4, p. 886-891, 2012.

FLOT, J.-F. SeqPHASE: a web tool for interconverting PHASE input/output files and fasta sequence alignments. Molecular Ecology Resources, v. 10, n. 1, p. 162-166, 2010.

FONTAINE, K. M.; COOLEY, J. R.; SIMON, C. Evidence for paternal leakage in hybrid periodical cicadas (Hemiptera: Magicicada spp.). PLoS ONE, v. 2, n. 9, p. e892, 2007. doi: 10.1371/journal.pone.0000892

FRANÇOSO, E.; ZUNTINI, A. R.; CARNAVAL, A. C.; ARIAS, M. C. Comparative phylogeography in the Atlantic forest and Brazilian savannas: pleistocene fluctuations and dispersal shape spatial patterns in two bumblebees. BMC Evolutionary Biology, v. 16, n. 1, p. 267, 2016. doi: 10.1186/s12862-016-0803-0

FREY, J. E.; FREY, B. Origin of intra-individual variation in PCR-amplified mitochondrial cytochrome oxidase I of Thrips tabaci (Thysanoptera: Thripidae): mitochondrial heteroplasmy or nuclear integration? Hereditas, v. 140, n. 2, p. 92-98, 2004.

GALTIER, N.; NABHOLZ, B.; GLÉMIN, S.; HURST, G. D. D. Mitochondrial DNA as a marker of molecular diversity: a reappraisal. Molecular Ecology, v. 18, n. 22, p. 4541-4550, 2009.

GARRATT, M. P. D.; COSTON, D. J.; TRUSLOVE, C. L.; LAPPAGE, M. G.; POLCE, C.; DEAN, R.; BIESMEIJER, J. C.; POTTS, S. G. The identity of crop pollinators helps target conservation for improved ecosystem services. Biological Conservation, v. 169, p. 128-135, 2014.

GILES, R. E.; BLANC, H.; CANN, H. M.; WALLACE, D. C. Maternal inheritance of human mitochondrial DNA. Proceedings of the National Academy of Sciences, v. 77, n. 11, p. 6715$6719,1980$.

GONZALEZ-FREIRE, M.; DE CABO, R.; BERNIER, M.; SOLLOTT, S. J.; FABBRI, E.; NAVAS, P.; FERRUCCI, L. Reconsidering the role of mitochondria in aging. The Journals of Gerontology Series A: Biological Sciences and Medical Sciences, v. 70, n. 11, p. 1334$1342,2015$.

GOULSON, D.; LYE, G. C.; DARVILL, B. Decline and conservation of bumble bees. Annual Review of Entomology, v. 53, n. 1, p. 191-208, 2008. 
GRAY, M. W. Mitochondrial evolution. Science, v. 283, n. 5407, p. 1476-1481, 1999.

GREENBERG, B. D.; NEWBOLD, J. E.; SUGINO, A. Intraspecific nucleotide mitochondrial DNA sequence variability surrounding the origin of replication in human. Gene, v. 21, p. 3349, 1983.

GUO, Y.; LI, J.; LI, C.-I.; SHYR, Y.; SAMUELS, D. C. MitoSeek: extracting mitochondria information and performing high-throughput mitochondria sequencing analysis. Bioinformatics, v. 29, n. 9, p. 1210-1211, 2013.

GYLLENSTEN, U.; WHARTON, D.; JOSEFSSON, A.; WILSON, A. C. Paternal inheritance of mitochondrial DNA in mice. Nature, v. 352, n. 6332, p. 255-257, 1991.

HANSFORD, R. Oxidative phosphorylation. In: Encyclopedia of Life Sciences. Chichester, UK: John Wiley \& Sons, Ltd, 2002. p. 621-642.

HATEFI, Y. The mitochondrial electron transport and oxidative phosphorylation system. Annual Review of Biochemistry, v. 54, n. 1, p. 1015-1069, 1985.

HAUSWIRTH, W. W.; LAIPIS, P. J. Mitochondrial DNA polymorphism in a maternal lineage of Holstein cows. Proceedings of the National Academy of Sciences, v. 79, n. 15, p. 46864690, 1982.

HAYASHI, J.-I.; YONEKAWA, H.; GOTOH, O.; WATANABE, J.; TAGASHIRA, Y. Strictly maternal inheritance of rat mitochondrial DNA. Biochemical and Biophysical Research Communications, v. 83, n. 3, p. 1032-1038, 1978.

HEBERT, P. D. N.; CYWINSKA, A.; BALL, S. L.; DEWAARD, J. R. Biological identifications through DNA barcodes. Proceedings of the Royal Society B: Biological Sciences, v. 270, n. 1512, p. 313-321, 2003.

HOARAU, G.; HOLLA, S.; LESCASSE, R.; STAM, W. T.; OLSEN, J. L. Heteroplasmy and Evidence for Recombination in the Mitochondrial Control Region of the Flatfish Platichthys flesus. Molecular Biology and Evolution, v. 19, n. 12, p. 2261-2264, 2002.

HOEKSTRA, R. F. Evolutionary origin and consequences of uniparental mitochondrial inheritance. Human Reproduction, v. 15, n. suppl 2, p. 102-111, 2000.

HOLT, I. J.; HARDING, A. E.; MORGAN-HUGHES, J. A. Deletions of muscle mitochondrial DNA in patients with mitochondrial myopathies. Nature, v. 331, n. 6158, p. 717-719, 1988.

HOLT, I. J.; MILLER, D. H.; HARDING, A. E. Genetic heterogeneity and mitochondrial DNA heteroplasmy in Leber's hereditary optic neuropathy. Journal of Medical Genetics, v. 26, n. 12, p. 739-743, 1989.

HOWELL, N.; CHINNERY, P. F.; GHOSH, S. S.; FAHY, E.; TURNBULL, D. M. Transmission of the human mitochondrial genome. Human Reproduction, v. 15, n. suppl 2, p. 235-245, 2000. 
HOWELL, N.; HALVORSON, S.; KUBACKA, I.; MCCULLOUGH, D. A.; BINDOFF, L. A.; TURNBULL, D. M. Mitochondrial gene segregation in mammals: is the bottleneck always narrow? Human Genetics, v. 90, n. 1-2, p. 117-20, set. 1992.

IRWIN, J. A.; SAUNIER, J. L.; NIEDERSTÄTTER, H.; STROUSS, K. M.; STURK, K. A.; DIEGOLI, T. M.; BRANDSTÄTTER, A.; PARSON, W.; PARSONS, T. J. Investigation of heteroplasmy in the human mitochondrial DNA control region: A synthesis of observations from more than 5000 global population samples. Journal of Molecular Evolution, v. 68, n. 5, p. 516-527, 2009.

JACOBS, H. T.; LEHTINEN, S. K.; SPELBRINK, J. N. No sex please, we're mitochondria: a hypothesis on the somatic unit of inheritance of mammalian mtDNA. BioEssays, v. 22, n. 6, p. 564-572, 2000.

JANSEN, R. P. S.; DE BOER, K. The bottleneck: mitochondrial imperatives in oogenesis and ovarian follicular fate. Molecular and Cellular Endocrinology, v. 145, n. 1-2, p. 81-88, 1998.

JAZIN, E. E.; CAVELIER, L.; ERIKSSON, I.; ORELAND, L.; GYLLENSTEN, U. Human brain contains high levels of heteroplasmy in the noncoding regions of mitochondrial DNA. Proceedings of the National Academy of Sciences, v. 93, n. 22, p. 12382-12387, 1996.

JENUTH, J. P.; PETERSON, A. C.; FU, K.; SHOUBRIDGE, E. A. Random genetic drift in the female germline explains the rapid segregation of mammalian mitochondrial DNA. Nature Genetics, v. 14, n. 2, p. 146-151, 1996.

JOHNSON, A. A.; JOHNSON, K. A. Fidelity of nucleotide incorporation by human mitochondrial DNA polymerase. Journal of Biological Chemistry, v. 276, n. 41, p. 3809038096, 2001.

JUVONEN, V.; HUOPONEN, K.; SYVÄNEN, A.-C.; NIKOSKELAINEN, E.; SAVONTAUS, M.-L. Quantification of point mutations associated with Leber hereditary optic neuroretinopathy by solid-phase minisequencing. Human Genetics, v. 93, n. 1, p. 16-20, 1994.

KANEDA, H.; HAYASHI, J.; TAKAHAMA, S.; TAYA, C.; LINDAHL, K. F.; YONEKAWA, H. Elimination of paternal mitochondrial DNA in intraspecific crosses during early mouse embryogenesis. Proceedings of the National Academy of Sciences, v. 92, n. 10, p. 45424546, 1995.

KANG, A. R.; KIM, M. J.; PARK, I. A.; KIM, K. Y.; KIM, I. Extent and divergence of heteroplasmy of the DNA barcoding region in Anapodisma miramae (Orthoptera: Acrididae). Mitochondrial DNA, v. 1736, p. 1-10, 2015.

KIRCHES, E.; MICHAEL, M.; WARICH-KIRCHES, M.; SCHNEIDER, T.; WEIS, S.; KRAUSE, G.; MAWRIN, C.; DIETZMANN, K. Heterogeneous tissue distribution of a mitochondrial DNA polymorphism in heteroplasmic subjects without mitochondrial disorders. Journal of Medical Genetics, v. 38, n. 5, p. 312-317, 2001.

KIVISILD, T.; METSPALU, M.; BANDELT, H.-J.; RICHARDS, M.; VILLEMS, R. The world mtDNA phylogeny. In: BANDELT, H.-J.; MACAULAY, V.; RICHARDS, M. (Ed.). Human Mitochondrial DNA and the Evolution of Homo sapiens. Berlin, Heidelberg: 
Springer Berlin Heidelberg, 2006. p. 149-179.

KMIEC, B.; WOLOSZYNSKA, M.; JANSKA, H. Heteroplasmy as a common state of mitochondrial genetic information in plants and animals. Current Genetics, v. 50, n. 3, p. 149$159,2006$.

KOEHLER, C. M.; LINDBERG, G. L.; BROWN, D. R.; BEITZ, D. C.; FREEMAN, A. E.; MAYFIELD, J. E.; MYERS, A. M. Replacement of bovine mitochondrial DNA by a sequence variant within one generation. Genetics, v. 129, n. 1, p. 247-55, 1991.

KONDO, R.; MATSUURA, E. T.; CHIGUSA, S. I. Further observation of paternal transmission of Drosophila mitochondrial DNA by PCR selective amplification method. Genetical Research, v. 59, n. 2, p. 81, 1992.

KUCEJ, M.; BUTOW, R. A. Evolutionary tinkering with mitochondrial nucleoids. Trends in Cell Biology, v. 17, n. 12, p. 586-592, 2007.

KUMAZAWA, Y. Mitochondrial DNA sequences of five squamates: phylogenetic affiliation of snakes. DNA Research, v. 11, n. 2, p. 137-144, 2004.

KUNKEL, T. A.; BEBENEK, K. DNA replication fidelity. Annual Review of Biochemistry, v. 69 , n. 1, p. 497-529, 2000.

KVIST, L.; MARTENS, J.; NAZARENKO, A. A.; ORELL, M. Paternal leakage of mitochondrial DNA in the great tit (Parus major). Molecular Biology and Evolution, v. 20, n. 2, p. 243-247, 2003.

LANG, B. F.; BURGER, G.; O'KELLY, C. J.; CEDERGREN, R.; GOLDING, G. B.; LEMIEUX, C.; SANKOFF, D.; TURMEL, M.; GRAY, M. W. An ancestral mitochondrial DNA resembling a eubacterial genome in miniature. Nature, v. 387, n. 6632, p. 493-497, 1997.

LANG, B. F.; GRAY, M. W.; BURGER, G. Mitochondrial genome evolution and the origin of eukaryotes. Annual Review of Genetics, v. 33, n. 1, p. 351-397, dez. 1999.

LEGROS, F. Organization and dynamics of human mitochondrial DNA. Journal of Cell Science, v. 117, n. 13, p. 2653-2662, 2004.

LIGHTOWLERS, R. N.; CHINNERY, P. F.; TURNBULL, D. M.; HOWELL, N. Mammalian mitochondrial genetics: heredity, heteroplasmy and disease. Trends in Genetics, v. 13, n. 11, p. 450-455, 1997.

LIN, M. T.; SIMON, D. K.; AHN, C. H.; KIM, L. M.; BEAL, M. F. High aggregate burden of somatic mtDNA point mutations in aging and Alzheimer's disease brain. Human Molecular Genetics, v. 11, n. 2, p. 133-145, 2002.

LINDHOLM, M.; D’AURIAC, M. A.; THAULOW, J.; HOBÆK, A. Dancing around the pole: holarctic phylogeography of the Arctic fairy shrimp Branchinecta paludosa (Anostraca, Branchiopoda). Hydrobiologia, v. 772, n. 1, p. 189-205, 2016. 
LYNCH, M. Mutation Pressure and the Evolution of Organelle Genomic Architecture. Science, v. 311, n. 5768, p. 1727-1730, 2006.

MAGNACCA, K. N.; DANFORTH, B. N. Evolution and biogeography of native Hawaiian Hylaeus bees (Hymenoptera: Colletidae). Cladistics, v. 22, n. 5, p. 393-411, 2006.

MARGARITOPOULOS, J. T.; GONDOSOPOULOS, B.; GOTOSOPOULOS, B.; MAMURIS, Z.; SKOURAS, P. J.; VOUDOURIS, K. C.; BACANDRITSOS, N.; FANTINOU, a a; TSITSIPIS, J. a. Genetic variation among Mediterranean populations of Sesamia nonagrioides (Lepidoptera: Noctuidae) as revealed by RFLP mtDNA analysis. Bulletin of Entomological Research, v. 97, n. 3, p. 299-308, 2007.

MASON, P. A.; LIGHTOWLERS, R. N. Why do mammalian mitochondria possess a mismatch repair activity? FEBS Letters, v. 554, n. 1-2, p. 6-9, 2003.

MATÉ, M. L.; DI ROCCO, F.; ZAMBELLI, A.; VIDAL-RIOJA, L. Mitochondrial heteroplasmy in Control Region DNA of South American camelids. Small Ruminant Research, v. 71, n. 1-3, p. 123-129, 2007.

MCINERNEY, P.; ADAMS, P.; HADI, M. Z. Error rate comparison during Polymerase Chain Reaction by DNA polymerase. Molecular Biology International, v. 2014, p. 1-8, 2014.

MCLEOD, B. a.; WHITE, B. N. Tracking mtDNA heteroplasmy through multiple generations in the North Atlantic right whale (Eubalaena glacialis). Journal of Heredity, v. 101, n. 2, p. 235-239, 2010.

MEISINGER, C.; SICKMANN, A.; PFANNER, N. The mitochondrial proteome: from inventory to function. Cell, v. 134, n. 1, p. 22-24, 2008.

MISHRA, P.; CHAN, D. C. Mitochondrial dynamics and inheritance during cell division, development and disease. Nature Reviews Molecular Cell Biology, v. 15, n. 10, p. 634-646, 2014.

MITOMAP: a human mitochondrial genome database. Disponível em: $<$ http://www.mitomap.org/>. Acesso em: 26 abr. 2017.

MORAES, C. T.; SCHON, E. A.; DIMAURO, S.; MIRANDA, A. F. Heteroplasmy of mitochondrial genomes in clonal cultures from patients with Kearns-Sayre syndrome. Biochemical and Biophysical Research Communications, v. 160, n. 2, p. 765-771, 1989.

MORITZ, C.; DOWLING, T. E.; BROWN, W. M. Evolution of animal mitochondrial DNA: relevance for population biology and systematics. Annual Review of Ecology and Systematics, v. 18, n. 1, p. 269-292, 1987.

MOUM, T.; BAKKE, I. Mitochondrial control region structure and single site heteroplasmy in the razorbill (Alca torda; Aves). Current Genetics, v. 39, n. 3, p. 198-203, 2001.

MOURE, J. S.; MELO, G. A. R. Bombini Latreille, 1802. In: MOURE, J. S.; URBAN, D.; MELO, G. A. R. (Ed.). Catalogue of Bees (Hymenoptera, Apoidea) in the Neotropical 
Region - online version. Disponível em: <http://moure.cria.org.br/catalogue?id=28972>. Acesso em: 09 de abr. 2017.

MUNDY, N. I.; WINCHELL, C. S.; WOODRUFF, D. S. Tandem repeats and heteroplasmy in the mitochondrial DNA Control Region of the loggerhead shrike (Lanius ludovicianus). Journal of Heredity, v. 87, n. 1, p. 21-26, 1996.

NARDI, F.; CARAPELLI, A.; FANCIULLI, P. P.; DALLAI, R.; FRATI, F. The Complete Mitochondrial DNA Sequence of the Basal Hexapod Tetrodontophora bielanensis: Evidence for Heteroplasmy and tRNA Translocations. Molecular Biology and Evolution, v. 18, n. 7, p. 1293-1304, 2001.

NASS, M. M. K. Mitochondrial DNA: I. Intramitochondrial distribution and structural relations of single- and double-length circular DNA. Journal of Molecular Biology, v. 42, n. 3, p. 521$528,1969$.

NAUE, J.; HÖRER, S.; SÄNGER, T.; STROBL, C.; HATZER-GRUBWIESER, P.; PARSON, W.; LUTZ-BONENGEL, S. Evidence for frequent and tissue-specific sequence heteroplasmy in human mitochondrial DNA. Mitochondrion, v. 20, p. 82-94, 2015.

NESBØ, C. L.; ARAB, M. O.; JAKOBSEN, K. S. Heteroplasmy, length and sequence variation in the mtDNA control regions of three percid fish species (Perca fluviatilis, Acerina cernua, Stizostedion lucioperca). Genetics, v. 148, n. 4, p. 1907-1919, 1998.

O'KELLY, C. J. The Jakobid Flagellates: Structural Features of Jakoba, Reclinomonas and Histiona and Implications for the Early Diversification of Eukaryotes. Journal of Eukaryotic Microbiology, v. 40, n. 5, p. 627-636, 1993.

PATWARDHAN, A.; RAY, S.; ROY, A. Molecular markers in phylogenetic studies - a review. Journal of Phylogenetics and Evolutionary Biology, v. 2, n. 2, p. 1-9, 2014.

PAYNE, B. A. I.; WILSON, I. J.; YU-WAI-MAN, P.; COXHEAD, J.; DEEHAN, D.; HORVATH, R.; TAYLOR, R. W.; SAMUELS, D. C.; SANTIBANEZ-KOREF, M.; CHINNERY, P. F. Universal heteroplasmy of human mitochondrial DNA. Human Molecular Genetics, v. 22, n. 2, p. 384-390, 2013.

RADOJIČIĆ, J. M.; KRIZMANIĆ, I.; KASAPIDIS, P.; ZOUROS, E. Extensive mitochondrial heteroplasmy in hybrid water frog (Pelophylax spp.) populations from Southeast Europe. Ecology and Evolution, v. 5, n. 20, p. 4529-4541, 2015.

RICHLY, E.; LEISTER, D. NUMTs in sequenced eukaryotic genomes. Molecular Biology and Evolution, v. 21, n. 6, p. 1081-1084, 2004.

ROBERTSON, B. C.; STEEVES, T. E.; MCBRIDE, K. P.; GOLDSTIEN, S. J.; WILLIAMS, M.; GEMMELL, N. J. Phylogeography of the New Zealand blue duck (Hymenolaimus malacorhynchos): Implications for translocation and species recovery. Conservation Genetics, v. 8, n. 6, p. 1431-1440, 2007.

ROBISON, G. A.; BALVIN, O.; SCHAL, C.; VARGO, E. L.; BOOTH, W. Extensive 
mitochondrial heteroplasmy in natural populations of a resurging human pest, the bed bug (Hemiptera: Cimicidae). Journal of Medical Entomology, v. 52, n. 4, p. 734-738, 2015.

ROKAS, A.; LADOUKAKIS, E.; ZOUROS, E. Animal mitochondrial DNA recombination revisited. Trends in Ecology \& Evolution, v. 18, n. 8, p. 411-417, 2003.

RÖTIG, A.; CORMIER, V.; BLANCHE, S.; BONNEFONT, J. P.; LEDEIST, F.; ROMERO, N.; SCHMITZ, J.; RUSTIN, P.; FISCHER, A.; SAUDUBRAY, J. M. Pearson's marrowpancreas syndrome. A multisystem mitochondrial disorder in infancy. Journal of Clinical Investigation, v. 86, n. 5, p. 1601-1608, 1990.

SATHANANTHAN, A. H.; TROUNSON, A. O. Mitochondrial morphology during preimplantational human embryogenesis. Human Reproduction, v. 15, p. 148-159, 2000.

SATO, M.; SATO, K. Degradation of paternal mitochondria by fertilization-triggered autophagy in C. elegans embryos. Science, v. 334, n. 6059, p. 1141-1144, 2011.

SATO, M.; SATO, K. Maternal inheritance of mitochondrial DNA by diverse mechanisms to eliminate paternal mitochondrial DNA. Biochimica et Biophysica Acta (BBA) - Molecular Cell Research, v. 1833, n. 8, p. 1979-1984, 2013.

SATOH, M.; KUROIWA, T. Organization of multiple nucleoids and DNA molecules in mitochondria of a human cell. Experimental Cell Research, v. 196, p. 137-140, 1991.

SAVOLAINEN, P.; ARVESTAD, L.; LUNDEBERG, J. mtDNA tandem repeats in domestic dogs and wolves: mutation mechanism studied by analysis of the sequence of imperfect repeats. Molecular Biology and Evolution, v. 17, n. 4, p. 474-488, 2000.

SHADEL, G. S.; CLAYTON, D. A. Mitochondrial DNA maintenance in vertebrates. Annual Review of Biochemistry, v. 66, n. 1, p. 409-435, 1997.

SHARPLEY, M. S.; MARCINIAK, C.; ECKEL-MAHAN, K.; MCMANUS, M.; CRIMI, M.; WAYMIRE, K.; LIN, C. S.; MASUBUCHI, S.; FRIEND, N.; KOIKE, M.; CHALKIA, D.; MACGREGOR, G.; SASSONE-CORSI, P.; WALLACE, D. C. Heteroplasmy of mouse mtDNA is genetically unstable and results in altered behavior and cognition. Cell, v. 151, n. 2, p. 333-343, 2012.

SHOUBRIDGE, E. A. Mitochondrial DNA segregation in the developing embryo. Human Reproduction, v. 15, n. suppl 2, p. 229-234, 2000.

SHOUBRIDGE, E. A.; WAI, T. Mitochondrial DNA and the Mammalian Oocyte. Current Topics in Developmental Biology, v. 77, n. 6, p. 87-111, 2007.

SIMON, C.; FRATI, F.; BECKENBACH, A.; CRESPI, B.; LIU, H.; FLOOK, P. Evolution, weighting, and phylogenetic utility of mitochondrial gene sequences and a compilation of conserved polymerase chain reaction primers. Annals of the Entomological Society of America, v. 87, n. 6, p. 651-701, 1994.

SOLIGNAC, M.; MONNEROT, M.; MOUNOLOU, J. C. Mitochondrial DNA heteroplasmy 
in Drosophila mauritiana. Proceedings of the National Academy of Sciences, v. 80, n. 22, p. 6942-6946, 1983.

SONDHEIMER, N.; GLATZ, C. E.; TIRONE, J. E.; DEARDORFF, M. a.; KRIEGER, A. M.; HAKONARSON, H. Neutral mitochondrial heteroplasmy and the influence of aging. Human Molecular Genetics, v. 20, n. 8, p. 1653-1659, 2011.

SONGRAM, O.; SITTIPRANEED, S.; KLINBUNGA, S. Mitochondrial DNA diversity and genetic differentiation of the honeybee (Apis cerana) in Thailand. Biochemical Genetics, v. 44 , n. 5-6, p. 256-269, 2006.

ST. JOHN, J. C.; COOKE, I. D.; BARRATT, C. L. R. Mitochondrial mutations and male infertility. Nature Medicine, v. 3, n. 2, p. 124-125, 1997.

ST. JOHN, J. C.; SAKKAS, D.; DIMITRIADI, K.; BARNES, A.; MACLIN, V.; RAMEY, J.; BARRATT, C.; DE JONGE, C. Failure of elimination of paternal mitochondrial DNA in abnormal embryos. The Lancet, v. 355, n. 9199, p. 200, 2000.

STEWART, J. B.; CHINNERY, P. F. The dynamics of mitochondrial DNA heteroplasmy: implications for human health and disease. Nature Reviews Genetics, v. 16, n. 9, p. 530-542, 2015.

SUNNUCKS, P. Efficient genetic markers for population biology. Trends in Ecology and Evolution, v. 15, n. 5, p. 199-203, 2000.

SUTOVSKY, P.; MORENO, R. D.; RAMALHO-SANTOS, J.; DOMINKO, T.; SIMERLY, C.; SCHATTEN, G. Ubiquitinated sperm mitochondria, selective proteolysis, and the regulation of mitochondrial inheritance in mammalian embryos. Biology of Reproduction, v. 63 , n. 2, p. 582-590, 2000.

THUNDATHIL, J.; FILION, F.; SMITH, L. C. Molecular control of mitochondrial function in preimplantation mouse embryos. Molecular Reproduction and Development, v. 71, n. 4, p. 405-413, 2005.

TSANG, W. Y.; LEMIRE, B. D. Stable heteroplasmy but differential inheritance of a large mitochondrial DNA deletion in nematodes. Biochemistry and Cell Biology, v. 80, n. 5, p. 645654, 2002.

VOLLMER, N. L.; VIRICEL, A.; WILCOX, L.; MOORE, K. M.; ROSEL, P. E. The occurrence of mtDNA heteroplasmy in multiple cetacean species. Current Genetics, v. 57, n. 2, p. 115-131, 2011.

VOLZ-LINGENHOHL, A.; SOLIGNAC, M.; SPERLICH, D. Stable heteroplasmy for a largescale deletion in the coding region of Drosophila subobscura mitochondrial DNA. Proceedings of the National Academy of Sciences, v. 89, n. 23, p. 11528-11532, 1992.

WALLACE, D. C. Diseases of the Mitochondrial DNA. Annual Review of Biochemistry, v. 61, n. 1, p. 1175-1212, 1992. 
WALLACE, D. C. The mitochondrial genome in human adaptive radiation and disease: on the road to therapeutics and performance enhancement. Gene, v. 354, p. 169-180, 2005.

WHITE, D. J.; WOLFF, J. N.; PIERSON, M.; GEMMELL, N. J. Revealing the hidden complexities of mtDNA inheritance. Molecular Ecology, v. 17, n. 23, p. 4925-4942, 2008.

WILKINSON, G. S.; CHAPMAN, A. M. Length and sequence variation in evening bat D-loop mtDNA. Genetics, v. 128, n. 3, p. 607-617, 1991.

WILLIAMS, P. Bumblebees of the world. Disponível em: <http://www.nhm.ac.uk/researchcuration/research/projects/bombus/index.html>. Acesso em: 15 maio. 2017.

WILLIAMS, P. H.; CAMERON, S. A.; HINES, H. M.; CEDERBERG, B.; RASMONT, P. A simplified subgeneric classification of the bumblebees (genus Bombus ). Apidologie, v. 39, n. 1, p. 46-74, 2008.

WOLFF, J. N.; WHITE, D. J.; WOODHAMS, M.; WHITE, H. E.; GEMMELL, N. J. The strength and timing of the mitochondrial bottleneck in salmon suggests a conserved mechanism in vertebrates. PLoS ONE, v. 6, n. 5, p. e20522, 2011. doi: 10.1371/journal.pone.0020522

YE, F.; SAMUELS, D. C.; CLARK, T.; GUO, Y. High-throughput sequencing in mitochondrial DNA research. Mitochondrion, v. 17, p. 157-163, 2014.

ZHANG, D.-X.; HEWITT, G. M. Nuclear integrations: challenges for mitochondrial DNA markers. Trends in Ecology \& Evolution, v. 11, n. 6, p. 247-251, 1996.

ZHANG, D.-X.; HEWITT, G. M. Assessment of the universality and utility of a set of conserved mitochondrial COI primers in insects. Insect Molecular Biology, v. 6, n. 2, p. 143$150,1997$.

ZHAO, X.; LI, N.; GUO, W.; HU, X.; LIU, Z.; GONG, G.; WANG, A.; FENG, J.; WU, C. Further evidence for paternal inheritance of mitochondrial DNA in the sheep (Ovis aries). Heredity, v. 93, n. 4, p. 399-403, 2004.

ZOUROS, E. Biparental inheritance through uniparental transmission: the doubly uniparental inheritance (DUI) of mitochondrial DNA. Evolutionary Biology, v. 40, n. 1, p. 1-31, 2013.

ZOUROS, E.; OBERHAUSER BALL, A.; SAAVEDRA, C.; FREEMAN, K. R. An unusual type of mitochondrial DNA inheritance in the blue mussel Mytilus. Proceedings of the National Academy of Sciences, v. 91, n. 16, p. 7463-7467, 1994. 


\title{
Capítulo 2
}

\section{Variação intraindividual do DNA mitocondrial em}

\section{Bombus morio}

\author{
Paulo Cseri Ricardo ${ }^{1}$, Elaine Françoso ${ }^{1}$ e Maria Cristina Arias ${ }^{1}$ \\ ${ }^{1}$ Departamento de Genética e Biologia Evolutiva - Instituto de Biociências - Universidade de \\ São Paulo, São Paulo, SP, Brasil.
}

\section{Resumo}

As sequências do DNA mitocondrial (mtDNA) são amplamente utilizadas como marcadores moleculares em estudos evolutivos e na identificação de espécies. No entanto, a presença de alguns fatores, como a heteroplasmia e NUMTs, podem ser empecilhos na utilização dessas sequências. A heteroplasmia é um estado onde um organismo possui diferentes haplótipos mitocondriais. NUMTs são pseudogenes nucleares originados de sequências do mtDNA transferidas para o DNA nuclear. Em um estudo anterior, de nosso grupo de pesquisa, foram encontrados indícios da presença de heteroplasmia na espécie de abelha Bombus morio. $\mathrm{O}$ trabalho atual investigou de forma mais detalhada a presença de variação intraindividual nessa espécie, e constatou além da heteroplasmia a ocorrência de NUMTs. A heteroplasmia foi detectada em indivíduos de todas as localidades amostradas, sendo observados em média seis haplótipos heteroplásmicos por indivíduo. Além disso, alguns desses haplótipos heteroplásmicos foram compartilhados entre indivíduos de diferentes localidades, sugerindo a existência de heteroplasmia estável em B. morio. Esses resultados demonstraram que a heteroplasmia pode influenciar em inferências baseadas em análises de sequências do mtDNA, especialmente em estudos filogenéticos, filogeográficos e de genética de populações. As sequências dos NUMTs apresentaram divergência de $2 \%$ a $12 \%$ em relação aos haplótipos mitocondriais. Esses níveis de divergência poderiam levar a conclusões equivocadas em estudos evolutivos e na identificação de espécies através do DNA barcoding.

Palavras-chave: Heteroplasmia, NUMTs, mtDNA, COI. 


\section{Abstract}

Mitochondrial DNA (mtDNA) sequences are widely used as molecular markers in evolutionary studies and species identification. However, the presence of heteroplasmy and NUMTs may represent obstacles in the use of these sequences. Heteroplasmy is a state where an organism has different mitochondrial haplotypes. NUMTs are nuclear pseudogenes originating from mtDNA sequences transferred to nuclear DNA. Evidences of heteroplasmy were already verified in the bumblebee Bombus morio in an earlier study. The present work investigated in more detail the presence of intraindividual haplotypes variation in this species. Heteroplasmy was detected in individuals from all sampled locations, with an average of six heteroplasmic haplotypes per individual. In addition, some of these heteroplasmic haplotypes were shared among individuals from different locations, suggesting the existence of stable heteroplasmy in B. morio. These results demonstrated that heteroplasmy is likely to affect inferences based on mtDNA analysis, especially in phylogenetic, phylogeographic and population genetics studies. In addition, NUMTs were also detected. These sequences showed divergence of $2 \%$ to $12 \%$ in relation to mitochondrial haplotypes. These levels of divergence could mislead conclusions in evolutionary studies and affect species identification through DNA barcoding.

Keywords: Heteroplasmy, NUMTs, mtDNA, COI. 


\subsection{Introdução}

Indiscutivelmente sequências do DNA mitocondrial (mtDNA) animal estão entre os marcadores moleculares mais utilizados em estudos evolutivos, tanto a nível interespecífico quanto populacional (GALTIER et al., 2009), além de serem amplamente utilizadas para a identificação molecular de espécies (KRESS et al., 2015). O emprego dessas sequências como marcadores se deve principalmente a algumas características do mtDNA, tais como: ter taxa de mutação alta; herança tipicamente materna; e haploidia (WHITE et al., 2008). No entanto, cada vez mais, estudos discutem a presença de complicadores na utilização de sequências do mtDNA, entre eles estão a presença de heteroplasmia e NUMTs (Nuclear mitocondrial pseudogenes) (SONG et al., 2008; BERTHIER et al., 2011; MAGNACCA; BROWN, 2012; HARAN et al., 2015). A heteroplasmia é um estado que configura a presença de mais de um haplótipo mitocondrial em um mesmo indivíduo (LIGHTOWLERS et al., 1997; KMIEC; WOLOSZYNSKA; JANSKA, 2006). Os NUMTs, por sua vez, são pseudogenes originados de sequências do mtDNA que foram transferidas para o DNA nuclear (nuDNA) (LOPEZ et al., 1994; RICHLY; LEISTER, 2004).

Os primeiros trabalhos descrevendo a presença de heteroplasmia e NUMTs em animais surgiram há mais de três décadas, no início dos anos de 1980 (HAUSWIRTH; LAIPIS, 1982; GELLISSEN et al., 1983; GREENBERG; NEWBOLD; SUGINO, 1983; HADLER; DIMITRIJEVIC; MAHALINGAM, 1983; JACOBS et al., 1983; SOLIGNAC; MONNEROT; MOUNOLOU, 1983; TSUZUKI et al., 1983). Pouco mais de uma década depois, Zhang e Hewitt (1996a; b) foram os precursores da discussão dos NUMTs como desafios na utilização de sequências do mtDNA. Desde então vários outros trabalhos foram desenvolvidos abordando os NUMTs sob essa perspectiva (VAN DER KUYL et al., 1995; SORENSON; QUINN, 1998; JENSEN-SEAMAN et al., 2004; SONG et al., 2008; HAZKANI-COVO; ZELLER; MARTIN, 2010; BERTHEAU et al., 2011; HARAN et al., 2015).

Na presença de heteroplasmia e/ou NUMTs, as amplificações via PCR podem gerar várias sequências não-idênticas, porém similares, dificultando a distinção entre as mesmas (IBARGUCHI; FRIESEN; LOUGHEED, 2006). A incapacidade de distinguir entre sequências parálogas e ortólogas do mtDNA compromete a utilização desses dados em análises filogenéticas (BERTHIER et al., 2011), uma vez que inferências em estudos evolutivos podem ser seriamente afetadas quando baseadas em filogenias propostas a partir de dados imprecisos (BAEZA; FUENTES, 2013). 
Apesar de a presença de heteroplasmia ser reconhecida como um problema em potencial na utilização de sequências do mtDNA (RUBINOFF; CAMERON; WILL, 2006), existem poucos trabalhos que realmente discutem e investigam a heteroplasmia nesse sentido. Dois principais fatores contribuem para isso. O primeiro é que é amplamente aceito que a heteroplasmia é uma condição provisória, desaparecendo em poucas gerações (SHOUBRIDGE, 2000; STEWART; CHINNERY, 2015). Essa transitoriedade é atribuída ao gargalo na população de mitocôndrias durante o início da embriogênese, seguido de um grande aumento ao longo da oogênese, que possibilitariam a rápida fixação de uma das variantes de mtDNA (HAUSWIRTH; LAIPIS, 1982; JANSEN; DE BOER, 1998). O segundo fator é que a heteroplasmia é pouco reportada em organismos não-modelo (VOLLMER et al., 2011), provavelmente porque sua existência nem sempre é evidente sem investigações mais detalhadas, o que faz com que esse estado seja considerado um evento raro. No entanto, em organismos modelo existem evidências de que a heteroplasmia é um caráter comum (SOLIGNAC; MONNEROT; MOUNOLOU, 1983; BOURSOT; YONEKAWA; BONHOMME, 1987; LECHER; BEZIAT; ALZIARI, 1994; SACHADYN et al., 2008; SHARPLEY et al., 2012) e em alguns casos estável (VOLZ-LINGENHOHL; SOLIGNAC; SPERLICH, 1992; PETIT et al., 1998; TSANG; LEMIRE, 2002; DOUBLET et al., 2008). Em humanos esse fenômeno tem sido bem documentado, em especial nos estudos de síndromes e disfunções mitocondriais (HOLT; HARDING; MORGAN-HUGHES, 1988; MORAES et al., 1989; RÖTIG et al., 1990; DIMAURO; SCHON, 2001), e mesmo em estudos de caráter evolutivo e molecular (COMAS; PÄÄBO; BERTRANPETIT, 1995; BENDALL; MACAULAY; SYKES, 1997; IRWIN et al., 2009).

Em contrapartida, tanto a heteroplasmia quanto NUMTs também podem ter utilidade como marcadores moleculares. A heteroplasmia pode ser utilizada em investigações forenses, aumentando a significância de uma correspondência quando a mesma heteroplasmia é encontrada na comparação entre duas sequências, indicando, por exemplo, relações de parentesco entre indivíduos (IVANOV et al., 1996; EICHMANN; PARSON, 2007). Os NUMTs, por sua vez, podem ser úteis como ferramentas em reconstruções filogenéticas (HAZKANI-COVO, 2009), pois quando essas são transferidas para o núcleo, essas sequências evoluem mais lentamente que no do mtDNA, preservando um estado ancestral do genoma mitocondrial (PERNA; KOCHER, 1996). Assim, o diagnóstico e isolamento desses elementos podem ser positivos para diversas análises. 
A visualização de picos duplos nos eletroferogramas é o método mais simples para inferir a ocorrência de heteroplasmia e NUMTs em amostras amplificadas via PCR, e é uma abordagem utilizada em vários estudos (BRANDSTÄTTER; NIEDERSTÄTTER; PARSON, 2004; SANTOS et al., 2008; GOIOS; CARVALHO; AMORIM, 2009; DUDU et al., 2012; MIRALDO et al., 2012). No entanto, é importante considerar que esses picos duplos também podem ser indícios de outras variáveis, como por exemplo, contaminação das amostras e erros de amplificação. O método mais adequado para identificar essas sequências é a clonagem dos produtos de PCR, onde é possível isolar as sequências de possíveis NUMTs e haplótipos heteroplásmicos (BUHAY, 2009).

Françoso et al. (2016) encontraram picos duplos em eletroferogramas contendo sequências do mtDNA da espécie de abelha Bombus morio, e sugeriram a hipótese de se tratar de heteroplasmia. A presença de heteroplasmia já foi descrita para outras espécies de abelhas. Magnacca e Danforth (2006) encontraram heteroplasmia em várias espécies do gênero de abelhas Hylaeus. Songram et al. (2006) constataram a presença de heteroplasmia em Apis cerana. NUMTs também já foram identificados nas abelhas Apis mellifera (PAMILO; VILJAKAINEN; VIHAVAINEN, 2007), Colletes stepheni (ANDRUS, 2003), e em diferentes espécies do gênero Melipona (CRISTIANO; FERNANDES-SALOMÃO; YOTOKO, 2012; RUIZ et al., 2013; FRANÇOSO; GOMES; ARIAS, 2015). Partindo dos resultados obtidos por Françoso et al. (2016) o presente trabalho tem por proposta investigar de forma detalhada a presença da variação intraindividual em B. morio e como isso pode impactar na utilização de sequências do mtDNA como marcador molecular.

\subsection{Metodologia}

\subsubsection{Amostragem e extração de mtDNA}

Foram utilizados 26 espécimes de B. morio, dos quais 25 foram coletados em trabalhos anteriores (FRANCISCO et al., 2016; FRANÇOSO et al., 2016). Esses indivíduos foram selecionados de acordo com sua localidade de origem de modo a representar a distribuição geográfica de B. morio no Brasil (Figura 2.1, Tabela 2.1).

O DNA foi extraído da perna traseira dos indivíduos utilizando o método de isolamento de mitocôndrias descrito por Françoso et al. (2015). Esse método consiste em separar a fração de mitocôndrias do restante do conteúdo celular, utilizando uma pequena quantidade de tecido, com o auxílio de homogeneizador do tipo Dounce seguido de sucessivas 
centrifugações. A partir da fração mitocondrial isolada, o mtDNA foi purificado empregandose o kit DNeasy® Blood \& Tissue (QIAGEN).

\begin{tabular}{llcc}
\hline $\mathbf{N}^{\mathbf{0}}$ & Localidade & UF & Sigla \\
\hline $\mathbf{1}$ & Igrapiúna & BA & IGR/BA \\
$\mathbf{2}$ & Brasília & DF & BRA/DF \\
$\mathbf{3}$ & Água Limpa & SP & ALI/SP \\
$\mathbf{4}$ & Teodoro Sampaio & SP & TSA/SP \\
$\mathbf{5}$ & São Paulo & SP & SPA/SP \\
$\mathbf{6}$ & Petrópolis & RJ & PET/RJ \\
$\mathbf{7}$ & Angra dos Reis & RJ & ADR/RJ \\
$\mathbf{8}$ & Chapecó & SC & CHA/SC \\
$\mathbf{9}$ & Presidente Nereu SC & PNE/SC \\
$\mathbf{1 0}$ & Caxias do Sul & RS & CDS/RS \\
\hline
\end{tabular}

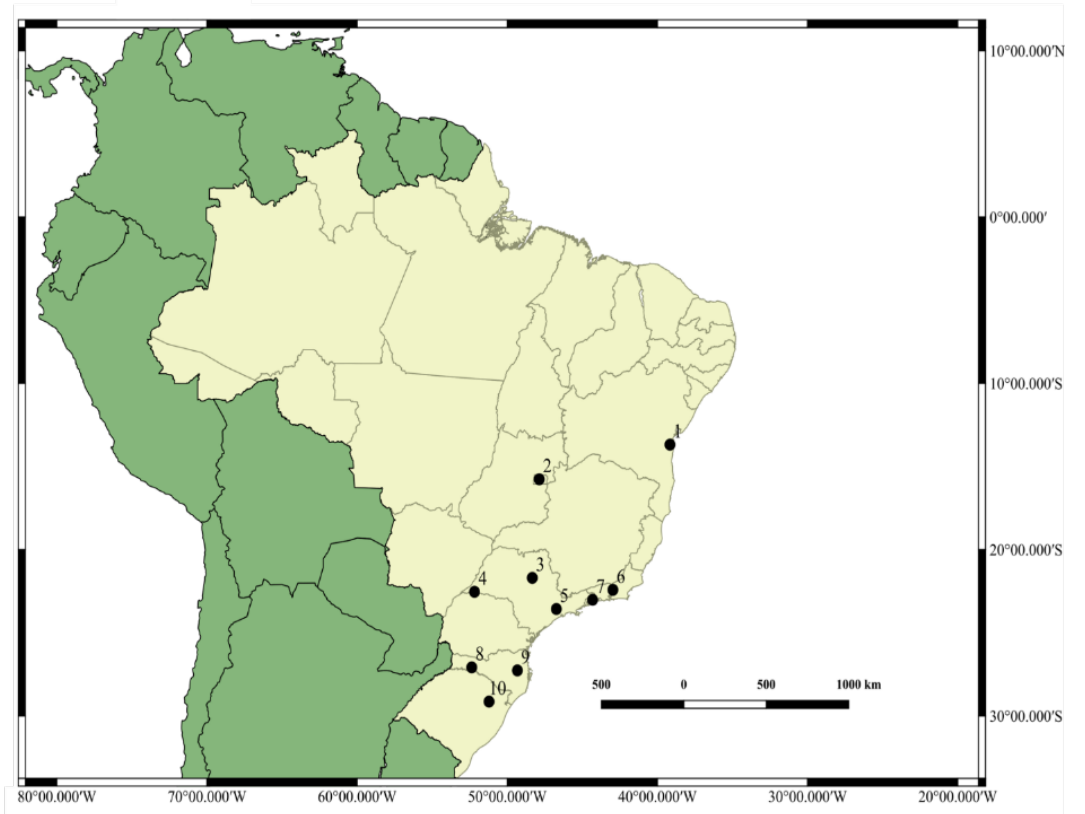

Figura 2.1. Mapa da localização dos pontos de coletas dos espécimes de B. morio utilizados neste trabalho, e legenda ao lado.

\subsubsection{Amplificação do gene $C O I$ e sequenciamento direto}

Foi amplificado um fragmento da região codificadora da enzima Citocromo c Oxidase (COI), compreendendo 670 pares de bases $(\mathrm{pb})$. A reação de amplificação via PCR foi padronizada para um volume final de $25 \mu 1$, contendo: $4 \mu 1$ da extração de mtDNA, 12,5 $\mu 1$ de Q5® High-Fidelity 2X Master Mix (New England Biolabs), e 0,8 $\mu \mathrm{M}$ dos primers Barbeef (5'CAACAAATCATAAAAATATTGG-3') (FRANÇOSO; ARIAS, 2013) e mtD9 (5'CCCGGTAAAATTAAAATATAAACTTC-3') (SIMON et al., 1994). Os ciclos de amplificação incluíram uma etapa inicial de desnaturação de 30 segundos a $98^{\circ} \mathrm{C}$, seguida por 35 ciclos contendo uma etapa de desnaturação de 10 segundos a $98^{\circ} \mathrm{C}$, uma etapa de hibridação de primers de 30 segundos a $50^{\circ} \mathrm{C}$, e uma etapa de extensão a $72^{\circ} \mathrm{C}$ por 30 segundos. Ao final dos ciclos seguiu-se uma etapa de extensão a $72^{\circ} \mathrm{C}$ por 2 minutos. Para cada indivíduo foram realizadas duas reações de PCR independentes. Os produtos de PCR foram purificados utilizando o kit QIAquick ${ }^{\circledR}$ PCR Purification (QIAGEN), e encaminhados para sequenciamento, realizado pela empresa Macrogen (Coréia do Sul) utilizando os primers Barbeef e mtD9. 


\subsubsection{Clonagem e sequenciamento dos insertos clonados}

A fim de ter acesso aos diferentes haplótipos mitocondriais existentes em cada indivíduo, os produtos de uma das reações de PCR foram clonados. Antes da etapa de clonagem foi realizada a adição de uma cauda poli-A aos amplicons purificados. Esse procedimento foi realizado para promover a ligação dos amplicons ao vetor plasmidial pGEM ${ }^{\circledR}-\mathrm{T}$ Easy (PROMEGA), seguindo as recomendações do fabricante para produtos produzidos por polimerases com atividade exonucleásica 3'- 5'. Em seguida, bactérias Escherichia coli competentes, da linhagem DH5- $\alpha$, foram transformadas com o vetor recombinante pelo método de choque térmico. Após a transformação as bactérias foram plaqueadas em meio de cultura LB-agar (SAMBROOK; FRITSCH; MANIATIS, 1989) contendo ampicilina (150 mg/L) e Xgal $(100 \mathrm{mg} / \mathrm{L})$. Para cada indivíduo de B. morio foram isoladas no mínimo 48 colônias contendo DNA recombinante. O DNA total dessas colônias foi extraído por fervura: as colônias foram ressuspendidas em $20 \mu \mathrm{l}$ de tampão TE $(0,5 \mathrm{X})$ e fervidas em um termociclador a $99^{\circ} \mathrm{C}$ por 10 minutos. Esse lisado foi utilizado para a amplificação subsequente dos insertos. As condições de amplificação foram: $1,5 \mathrm{mM}$ de $\mathrm{MgCl}_{2}, 0,2 \mathrm{mM}$ de cada $\mathrm{dNTP}, 0,4 \mu \mathrm{M}$ dos primers pUC/M13 forward (5'-GTTTTCCCAGTCACGAC-3') e pUC/M13 reverse (5'CAGGAAACAGCTATGAC-3'), 1,5 U de Platinum ${ }^{\circledR}$ Taq DNA Polymerase (Thermo Fisher Scientific) e $4 \mu 1$ do lisado, em um volume final de $20 \mu 1$. Os ciclos de amplificação incluíram uma etapa inicial de desnaturação a $94^{\circ} \mathrm{C}$ por 2 minutos, seguida por 35 ciclos contendo uma etapa de desnaturação a $94^{\circ} \mathrm{C}$ por 45 segundos, uma etapa de hibridação de primers a $48^{\circ} \mathrm{C}$ por 45 segundos e uma etapa de extensão de 50 segundos a $64^{\circ} \mathrm{C}$. Ao final dos ciclos seguiu-se uma etapa de extensão de 5 minutos a $64^{\circ} \mathrm{C}$. Os produtos dessas PCRs foram purificados com a enzima ExoProStar ${ }^{\circledR}$ (GE Healthcare Life Sciences) e enviados para sequenciamento na Macrogen (Coréia do Sul).

\subsubsection{Determinação dos haplótipos intraindividuais}

As sequências clonadas que apresentaram um índice de qualidade Phred (EWING et al., 1998) inferior a 20 foram excluídas das análises. As selecionadas foram editadas e alinhadas no software GENEIOUS 9.1.6 (KEARSE et al., 2012). O tamanho final das sequências após o alinhamento foi de $569 \mathrm{pb}$. As sequências foram checadas em relação a presença de mudanças no quadro de leitura e códons de parada prematuros. Também foi verificada a identidade das sequências através de buscas no banco de dados Nucleotide collection ( $n r / n t$ ) utilizando o algoritmo Megablast (ZHANG et al., 2000), implementados no website do NCBI 
(https://blast.ncbi.nlm.nih.gov/Blast.cgi). Além disso, foram calculadas as distâncias par-a-par não corrigidas (pairwise p-distances) entre as sequências de um mesmo indivíduo. As distâncias foram calculadas utilizando o pacote APE 4.0 (PARADIS; CLAUDE; STRIMMER, 2004) no ambiente R 3.3.1 (R CORE TEAM, 2016). A quantificação do número de haplótipos por indivíduo obtidos a partir das sequências clonadas foi realizada no ambiente $\mathrm{R}$ utilizando o pacote PEGAS 0.9 (PARADIS, 2010). Também foi calculado o número de haplótipos utilizando o conjunto total de sequências dos 26 indivíduos.

\subsubsection{Caracterização das mutações}

O número total de mutações sinônimas e não sinônimas entre as sequências nucleotídicas de todos os haplótipos foi quantificado utilizando o software DNAsp 5.10.01 (LIBRADO; ROZAS, 2009).

As sequências nucleotídicas dos haplótipos foram traduzidas para sequências de aminoácidos e alinhadas no programa GENEIOUS. A sequência consenso desse alinhamento foi extraída (188 resíduos de aminoácidos). Para a confirmação da correspondência dessa sequência à subunidade I do complexo Citocromo c Oxidase, ela foi alinhada com as sequências completas dessa proteína disponíveis nos bancos de dados UniProtKB/TrEMBL e UniProtKB/Swiss-Prot das espécies Bombus terrestris (UniProt: A0A0N7J5N9), Bombus ignitus (UniProt: A4UAH5) e Apis mellifera ligustica (UniProt: P20374-1).

Uma vez confirmada que a sequência consenso correspondia a um trecho da subunidade I do complexo Citocromo c Oxidase, ela foi utilizada como a sequência "selvagem" para verificar o efeito de substituições de aminoácidos em relação à função da proteína. Essa verificação foi realizada por dois métodos distintos, utilizando o algoritmo SIFT (KUMAR; HENIKOFF; NG, 2009) implementado no website do J. Craig Venter Institute (http://sift.jcvi.org/www/SIFT_seq_submit2.html), e o método SUSPECT (YATES et al., 2014) disponível no website do Structural Bioinformatics Group do Imperial College of London (http://www.sbg.bio.ic.ac.uk/suspect/).

O método SUSPECT prediz, a partir de uma sequência de aminoácidos selvagem, a suscetibilidade de uma mutação estar associada a uma doença, através da predição do fenótipo produzido por cada um dos 20 aminoácidos em determinada posição, sendo essa suscetibilidade representada por uma pontuação de 0 a 100, de forma crescente. O algoritmo SIFT prediz se a substituição de um aminoácido é tolerável ou não em uma determinada sequência, baseando-se na probabilidade dessa substituição ocorrer, sendo essa probabilidade calculada utilizando uma 
base de dados determinada pelo usuário. O banco de dados utilizado foi o UniProtKB/SwissProt 57.15.

\subsubsection{Efeito da variação intraindividual na topologia intraespecífica de $B$. morio}

A relação entre os haplótipos obtidos a partir do sequenciamento dos clones dos 26 , indivíduos foi visualizada em uma rede haplotípica obtida pelo programa POPART 1.7 (LEIGH; BRYANT, 2015) e utilizando o algoritmo median-joining (BANDELT; FORSTER; ROHL, 1999). Haplótipos que foram encontrados apenas uma vez e que estavam relacionados a outros mais frequentes por apenas uma mutação, formando o padrão de "estrela", foram excluídos das análises, pois podem ser decorrentes de erros de amplificação (ver Capítulo 2).

Também foram recuperadas topologias a partir de dois conjuntos de dados: (1) as sequências de todos os haplótipos intraindividuais e NUMTs; (2) os haplótipos mitocondriais mais frequentes para cada indivíduo. Essas topologias foram construídas baseadas em inferência bayesiana, implementada no programa MrBayes 3.2.6 (RONQUIST et al., 2012). Os modelos de substituição nucleotídica mais adequados foram especificados entre 24 modelos utilizando o Critério de Informação de Akaike (Akaike Information Criterion - AIC) no jModelTest 2.1.10 (DARRIBA et al., 2012). Os modelos definidos para cada conjunto de dados foram: (1) GTR $+\mathrm{I}+\mathrm{G}$ e (2) GTR $+\mathrm{I}$. Esses resultados foram comparados com a topologia recuperada em Françoso et al. (2016).

\subsubsection{Efeito da variação intraindividual na identificação de espécies}

Foram comparadas as distribuições de p-distance intraindividuais (dados das sequências clonadas) e interespecíficas, utilizando sequências de espécies do subgênero Thoracobombus, ao qual B. morio pertence (WILLIAMS, 2017). As sequências utilizadas para essas comparações foram das espécies: B. morio (haplótipo mais frequente obtido neste trabalho), Bombus dahlbomii (GenBank: KX820991), Bombus excellens (GenBank: KC853321), Bombus brevivillus (GenBank: KJ848951), Bombus applanatus (GenBank: KT187870), Bombus pauloensis (GenBank: KT187865), Bombus brasiliensis (GenBank: KT187887), Bombus bahiensis (GenBank: KJ848944), Bombus opifex (GenBank: KC853365), Bombus transversalis (GenBank: KJ848950), Bombus fervidus (GenBank: KR895885), e Bombus pensylvanicus (GenBank: KC853361). 


\subsection{Resultados}

\subsubsection{Presença de heteroplasmia e NUMTs}

No total foram obtidas 974 sequências da região do gene COI. Em 23 dos 26 indivíduos amostrados foi observada a existência de variação intraindividual. Nos espécimes com variação intraindividual o número de haplótipos mitocondriais variou entre 2 e 10 (Tabela 2.1). Esses indivíduos exibiram um haplótipo mais frequente, geralmente representado por mais de $50 \%$ das sequências clonadas. No entanto, em dois dos indivíduos analisados (18BM e 22BM) foram observados haplótipos intraindividuais com frequências muito próximas. Como a diferença entre as frequências desses haplótipos poderia ser decorrente da amostragem, esses haplótipos foram considerados como os mais frequentes para esses dois indivíduos.

A maior parte $(98,15 \%)$ das sequências recuperadas apresentaram entre $98 \%$ e $100 \%$ de identidade com sequências do gene COI de B. morio depositadas no GenBank. Essas sequências não apresentaram mudanças no quadro de leitura ou códons de parada prematuros, sugerindo que são funcionais. A maioria dos haplótipos intraindividuais, incluindo os haplótipos mais frequentes de cada indivíduo, é funcional. Esses haplótipos foram considerados haplótipos heteroplásmicos.

Por outro lado, foram observadas nove sequências com similaridade inferior a 97\% em relação às sequências de $B$. morio depositadas no GenBank. Essas sequências também apresentaram distância genética superior à $2 \%$ em relação aos demais haplótipos encontrados nos espécimes estudados. Além disso, em seis dessas sequências foi constatada a presença de características como mudanças no quadro de leitura, códons de parada e acúmulo de mutações independentemente da posição no códon, que são comumente encontradas em NUMTs (OLSON; YODER, 2002; FREY; FREY, 2004; CALVIGNAC et al., 2011). Essas nove sequências foram classificadas como NUMTs. 
Tabela 2.1. Relação dos indivíduos, das localidades nas quais foram coletados, o número de sequências obtidas e o número de haplótipos e NUMTS encontrados.

\begin{tabular}{|c|c|c|c|c|c|}
\hline Indivíduo & Localidade & $\begin{array}{l}\text { Número de clones } \\
\text { sequenciados }\end{array}$ & NUMTs & $\begin{array}{c}\text { Número de } \\
\text { haplótipos } \\
\text { mitocondriais (h) }\end{array}$ & $\begin{array}{l}\text { Freq. haplótipo } \\
\text { mais comum (\%) }\end{array}$ \\
\hline $3 \mathrm{BM}$ & IGR/BA & 31 & 3 & 8 & 45,2 \\
\hline $4 \mathrm{BM}$ & IGR/BA & 55 & 3 & 9 & 50,9 \\
\hline $5 \mathrm{BM}$ & IGR/BA & 48 & 2 & 7 & 45,8 \\
\hline $6 \mathrm{BM}$ & BRA/DF & 43 & - & 6 & 81,4 \\
\hline $7 \mathrm{BM}$ & BRA/DF & 32 & - & 8 & 40,6 \\
\hline $8 \mathrm{BM}$ & ALI/SP & 46 & - & 10 & 63 \\
\hline $9 \mathrm{BM}$ & ALI/SP & 34 & 1 & 4 & 76,5 \\
\hline $10 \mathrm{BM}$ & $\mathrm{ALI} / \mathrm{SP}$ & 36 & 1 & 8 & 52,8 \\
\hline $21 \mathrm{BM}$ & TSA/SP & 37 & - & 10 & 48,6 \\
\hline $22 \mathrm{BM}$ & TSA/SP & 35 & 1 & 9 & $31,4-28,6$ \\
\hline $34 \mathrm{BM}$ & $\mathrm{TSA} / \mathrm{SP}$ & 52 & - & 11 & 42,3 \\
\hline $23 \mathrm{BM}$ & SPA/SP & 38 & 1 & 7 & 57,9 \\
\hline $24 \mathrm{BM}$ & SPA/SP & 24 & - & 7 & 75 \\
\hline $25 \mathrm{BM}$ & SPA/SP & 40 & - & 5 & 90 \\
\hline $35 \mathrm{BM}$ & SPA/SP & 29 & - & 1 & 100 \\
\hline $40 \mathrm{BM}$ & SPA/SP & 34 & - & 1 & 100 \\
\hline $32 \mathrm{BM}$ & $\mathrm{PET} / \mathrm{RJ}$ & 26 & - & 6 & 73,1 \\
\hline $30 \mathrm{BM}$ & $\mathrm{PET} / \mathrm{RJ}$ & 51 & - & 6 & 86,3 \\
\hline $26 \mathrm{BM}$ & ADR/RJ & 31 & - & 2 & 87,1 \\
\hline $18 \mathrm{BM}$ & $\mathrm{CHA} / \mathrm{SC}$ & 38 & - & 9 & $26,3-23,7$ \\
\hline $19 \mathrm{BM}$ & $\mathrm{CHA} / \mathrm{SC}$ & 33 & - & 8 & 66,7 \\
\hline $20 \mathrm{BM}$ & $\mathrm{CHA} / \mathrm{SC}$ & 38 & - & 4 & 89,5 \\
\hline $1 \mathrm{BM}$ & $\mathrm{PNE} / \mathrm{SC}$ & 33 & - & 8 & 30,3 \\
\hline $2 \mathrm{BM}$ & $\mathrm{CDS} / \mathrm{RS}$ & 44 & - & 1 & 100 \\
\hline $11 \mathrm{BM}$ & $\mathrm{CDS} / \mathrm{RS}$ & 35 & 1 & 7 & 68,6 \\
\hline $14 \mathrm{BM}$ & $\mathrm{CDS} / \mathrm{RS}$ & 31 & - & 2 & 96,8 \\
\hline
\end{tabular}

\subsubsection{Sequenciamento direto e análise dos picos duplos}

Os eletroferogramas resultantes do sequenciamento direto foram analisados em relação a presença de picos duplos, e comparados com os obtidos por Françoso et al. (2016). Além disso, foi verificado se os picos duplos correspondiam a sítios polimórficos presentes entre os haplótipos heteroplásmicos. A análise visual desses eletroferogramas revelou picos duplos nas posições onde ocorriam mutações heteroplásmicas, principalmente em sítios onde a frequência de heteroplasmia foi superior a $20 \%$. No entanto, nem sempre foram verificados 
picos duplos em sítios que apresentaram variação intraindividual (análise dos clones). Foram observadas diferenças entre os eletroferogramas das duas reações de PCR realizadas para cada indivíduo. Alguns sítios, que nas sequências clonadas exibiram variação superior a $20 \%$, não apresentaram picos duplos, principalmente nos eletroferogramas gerados nos sequenciamentos diretos da segunda reação de PCR (Figura 2.2). Os eletroferogramas dessa reação, para alguns indivíduos, também exibiram a base menos frequente nas sequências clonadas. Por exemplo, em um sítio onde nos clones a base mais frequente foi uma citosina, nos eletroferogramas gerados no sequenciamento direto da PCR 2 o pico foi uma timina (Figura 2.2A). Também foram observadas diferenças entre os eletroferogramas obtidos nos sequenciamentos da primeira reação de PCR, como a altura do sinal de cada base, nas posições onde os picos duplos ocorreram (Figura 2.2B).

A maior parte dos picos duplos observados nos eletroferogramas gerados no trabalho de Françoso et al. (2016) também estão presentes nos eletroferogramas obtidos nos sequenciamentos nas direções forward e reverse da PCR 1, embora, assim como nas comparações anteriores, algumas diferenças foram encontradas (Figura 2.2B).

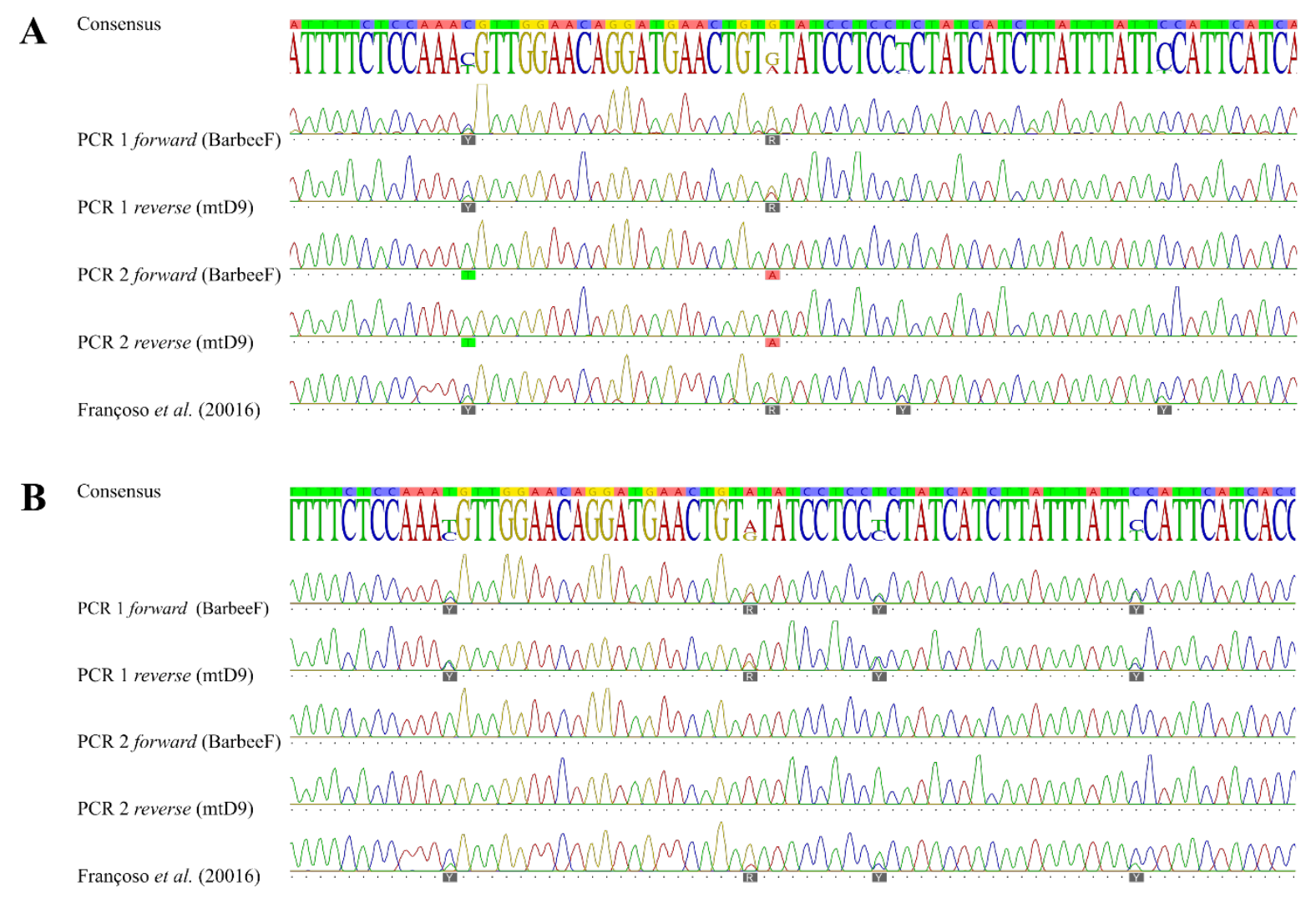

Figura 2.2. Alinhamento de um trecho de eletroferograma de sequenciamento direto dos produtos de PCR. Foram utilizadas sequências dos indivíduos 21BM (A) e 22BM (B) obtidas no presente estudo e por Françoso et al (2016). Os alinhamentos exemplificam discrepâncias entre as sequências de reações de PCR diferentes. Os gráficos acima dos eletroferogramas representam as sequências clonadas. O tamanho das letras, correspondentes às bases, representa sua frequência. 


\subsubsection{Caracterização das mutações}

Examinando conjuntamente as sequências dos 26 indivíduos amostrados, foi possível recuperar no total 47 haplótipos mitocondriais e 11 NUMTs. O alinhamento dessas sequências nucleotídicas identificou 95 mutações no total (Figura 2.3), sendo 62 sinônimas e 33 não sinônimas. A maioria das mutações foi verificada nas sequências classificadas como NUMTs, que também apresentaram uma proporção maior de mutações não sinônimas quando comparadas com as sequências heteroplásmicas (Tabela 2.2).

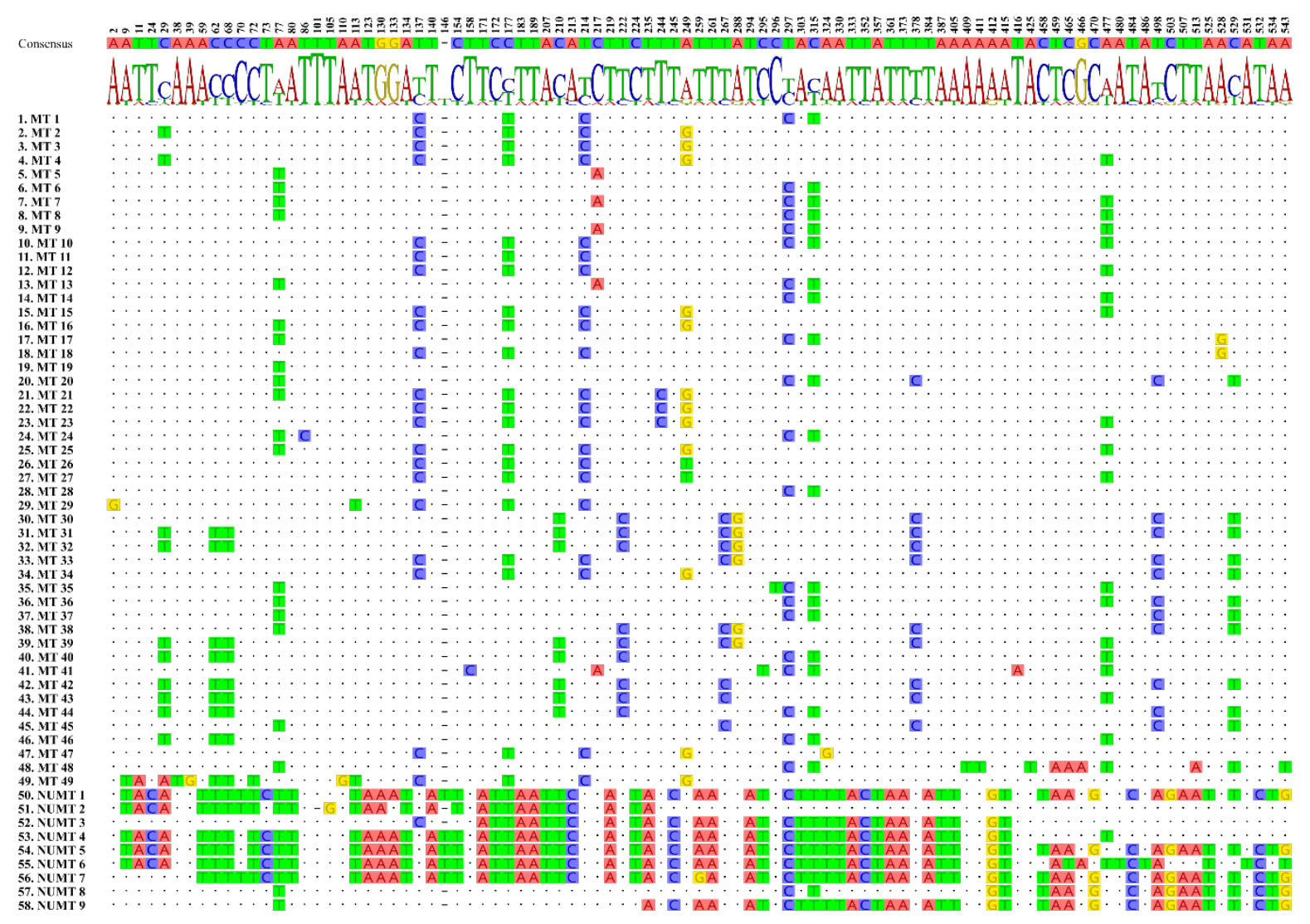

Figura 2.3. Alinhamento dos sítios variáveis observados entre as sequências nucleotídicas dos haplótipos mitocondriais e os NUMTs dos 26 indivíduos amostrados. Cada nucleotídeo está representado por sua respectiva cor (A: vermelho; C: azul; G: amarelo; e T: verde). Os pontos representam semelhança com a sequência consenso. A posição de cada sítio está indicada no topo. $O$ tamanho das letras que correspondem às bases no gráfico entre a sequência consenso e o alinhamento representa a sua respectiva frequência.

Tabela 2.2. Classificação das mutações intraindividuais observadas nas sequências nucleotídicas clonadas de todos os indivíduos analisados.

\begin{tabular}{cccc}
\hline Tipo de & \multicolumn{2}{c}{ Mutações intraindividuais } & \multirow{2}{*}{ Média de mutações por indivíduo* } \\
mutação & Heteroplasmia & NUMTs & 17,77 \\
\hline Sinônima & 35 & 27 & 6,73 \\
Não sinônima & 9 & 24 & tanto NUMTs quanto a \\
\hline *A média de mutações & por indivíduo foi calculada levando em consideração & \\
heteroplasmia.
\end{tabular}


Nas sequências heteroplásmicas foi predominante a ocorrência de mutações sinônimas, sendo poucos os haplótipos que apresentaram mutações não sinônimas, as quais foram observadas em apenas 9 sítios (nas posições 9, 39, 158, 217, 296, 409, 416, 425 e 466).

Das 9 sequências de NUMT, cinco (NUMT 1, NUMT 4, NUMT 5, NUMT 6 e NUMT 7) apresentaram uma inserção na posição 146, e uma (NUMT 2) apresentou uma deleção na posição 101. Esses indels foram responsáveis pela mudança do quadro de leitura e a presença de códons de parada prematuros. Assim, essas sequências não foram analisadas quanto ao efeito das mutações em relação a função da proteína.

Após a tradução das sequências nucleotídicas para sequências de aminoácidos, 908 sequências se mostraram idênticas. Dentre as sequências distintas, a substituição de aminoácido mais frequente ocorreu na posição 72, que consistiu na substituição de uma Leucina por uma Isoleucina (Tabela 2.3). As análises utilizando o SUSPECT e o SIFT revelaram que essa substituição é tolerada, e aparentemente não é desfavorável para a função da proteína.

Tabela 2.3. Relação entre as substituições de aminoácidos (representados segundo o código da IUPAC), com suas respectivas posições, as sequências com essas substituições, e o efeito predito de cada uma de acordo com o método SUSPECT e o algoritmo SIFT.

\begin{tabular}{|c|c|c|c|c|c|}
\hline Substituição & Posição & Sequência & Frequência* & $\begin{array}{l}\text { Predição } \\
\text { SUSPECT }\end{array}$ & $\begin{array}{l}\text { Predição } \\
\text { SIFT }\end{array}$ \\
\hline $\mathrm{I} \rightarrow \mathrm{L}$ & 3 & MT 49 & 1 & 12 & Tolerada \\
\hline $\mathrm{M} \rightarrow \mathrm{V}$ & 13 & MT 49 & 1 & 13 & Tolerada \\
\hline $\mathrm{L} \rightarrow \mathrm{S}$ & 52 & MT 41 & 1 & 80 & Não tolerada \\
\hline $\mathrm{P} \rightarrow \mathrm{S}$ & 57 & NUMT 3 & 1 & 40 & Tolerada \\
\hline $\mathrm{W} \rightarrow \mathrm{C}$ & 70 & NUMT 3 & 1 & 98 & Não tolerada \\
\hline $\mathrm{L} \rightarrow \mathrm{I}$ & 72 & $\begin{array}{c}\text { MT 13, MT 41, MT 5, MT } \\
\text { 7, MT } 9\end{array}$ & 47 & 39 & Tolerada \\
\hline $\mathrm{P} \rightarrow \mathrm{L}$ & 74 & NUMT 3 & 1 & 83 & Não tolerada \\
\hline $\mathrm{L} \rightarrow \mathrm{M}$ & 78 & NUMT 3, NUMT 9 & 2 & 42 & Não tolerada \\
\hline $\mathrm{L} \rightarrow \mathrm{S}$ & 81 & NUMT 3, NUMT 9 & 2 & 21 & Tolerada \\
\hline $\mathrm{S} \rightarrow \mathrm{T}$ & 86 & NUMT 3, NUMT 9 & 2 & 24 & Não tolerada \\
\hline $\mathrm{P} \rightarrow \mathrm{L}$ & 98 & MT 35 & 2 & 99 & Não tolerada \\
\hline $\mathrm{P} \rightarrow \mathrm{S}$ & 98 & $\begin{array}{c}\text { MT 41, NUMT } 3, \\
\text { NUMT } 9\end{array}$ & 3 & 99 & Não tolerada \\
\hline $\mathrm{S} \rightarrow \mathrm{T}$ & 120 & NUMT 3, NUMT 9 & 2 & 23 & Tolerada \\
\hline $\mathrm{S} \rightarrow \mathrm{T}$ & 124 & NUMT 3, NUMT 9 & 2 & 68 & Não tolerada \\
\hline $\mathrm{M} \rightarrow \mathrm{F}$ & 136 & MT 48 & 1 & 25 & Tolerada \\
\hline $\mathrm{M} \rightarrow \mathrm{V}$ & 137 & $\begin{array}{l}\text { NUMT 3, NUMT 8, } \\
\text { NUMT } 9\end{array}$ & 3 & 56 & Não tolerada \\
\hline $\mathrm{M} \rightarrow \mathrm{K}$ & 138 & MT 41 & 1 & 92 & Não tolerada \\
\hline $\mathrm{M} \rightarrow \mathrm{L}$ & 138 & $\begin{array}{l}\text { NUMT 3, NUMT 8, } \\
\text { NUMT } 9\end{array}$ & 3 & 66 & Tolerada \\
\hline $\mathrm{Y} \rightarrow \mathrm{F}$ & 141 & MT 48 & 1 & 17 & Tolerada \\
\hline $\mathrm{S} \rightarrow \mathrm{L}$ & 152 & NUMT 8, NUMT 9 & 2 & 82 & Não tolerada \\
\hline $\mathrm{V} \rightarrow \mathrm{I}$ & 155 & MT 48 & 1 & 12 & Tolerada \\
\hline $\mathrm{S} \rightarrow \mathrm{C}$ & 156 & NUMT 8, NUMT 9 & 2 & 65 & Não tolerada \\
\hline $\mathrm{P} \rightarrow \mathrm{R}$ & 167 & NUMT 9, NUMT 9 & 2 & 98 & Não tolerada \\
\hline
\end{tabular}

*Número de sequências clonadas onde a substituição foi observada 
A maioria das substituições preditas como não toleradas tanto pelo método SUSPECT quanto pelo algoritmo SIFT foram observadas nas sequências de aminoácidos traduzidas de possíveis NUMTs (NUMT 3, NUMT 8, NUMT 9). No entanto, também foram verificadas substituições preditas como não toleradas em haplótipos classificados como heteroplásmicos (MT 35 e MT 41).

\subsubsection{Efeito da variação intraindividual na topologia intraespecífica de B. morio}

Dos 49 haplótipos mitocondriais obtidos na amostragem total, 31 estavam em estado heteroplásmico em mais de um indivíduo, sendo os haplótipos MT 3, MT 6, MT 7 e MT 8 os mais frequentemente compartilhados (12, 15, 14 e 18 indivíduos, respectivamente) (Figura 2.4). Ainda, esses haplótipos foram verificados em indivíduos coletados em localidades diferentes, incluindo as dos extremos da distribuição amostrada.

Os haplótipos mitocondriais mais distantes, ou seja, com maior divergência de sequência em relação aos demais, foram os haplótipos MT 48 e MT 49, que apresentaram valores de distância entre 1,6-3,7\% e 1,8-4,8\% respectivamente. Contudo, esses haplótipos foram pouco frequentes, sendo ambos representados apenas por uma sequência clonada. Os haplótipos mais frequentes verificados nos espécimes coletados em Teodoro Sampaio também apresentaram grande divergência (1,8-3\%) em relação aos demais haplótipos mitocondriais. No entanto, esses indivíduos também apresentaram haplótipos detectados em indivíduos de outras localidades.

Todas as sequências dos NUMTs apresentaram vários passos mutacionais em relação aos haplótipos mitocondriais. Com exceção do NUMT 2, a análise obtida por inferência bayesiana recuperou uma topologia onde todos os NUMTs e o haplótipo MT 48 formaram um grupo isolado (Figura 2.5). Do mesmo modo, os haplótipos dos indivíduos de Teodoro Sampaio foram agrupados isoladamente (TSA/SP 1 e TSA/SP 2). O comprimento dos ramos desses agrupamentos (NUMTs e TSA) evidencia a divergência existente entre esses haplótipos/sequências dos demais.

$\mathrm{Na}$ construção da topologia entre os haplótipos mais frequentes em cada indivíduo, os haplótipos de Teodoro Sampaio formaram um agrupamento separado das demais sequências mitocondriais (Figura 2.6). No entanto, um dos haplótipos (MT 8) do indivíduo 22BM foi compartilhado com indivíduos de outras localidades, e agrupou juntamente com as demais sequências mitocondriais. 


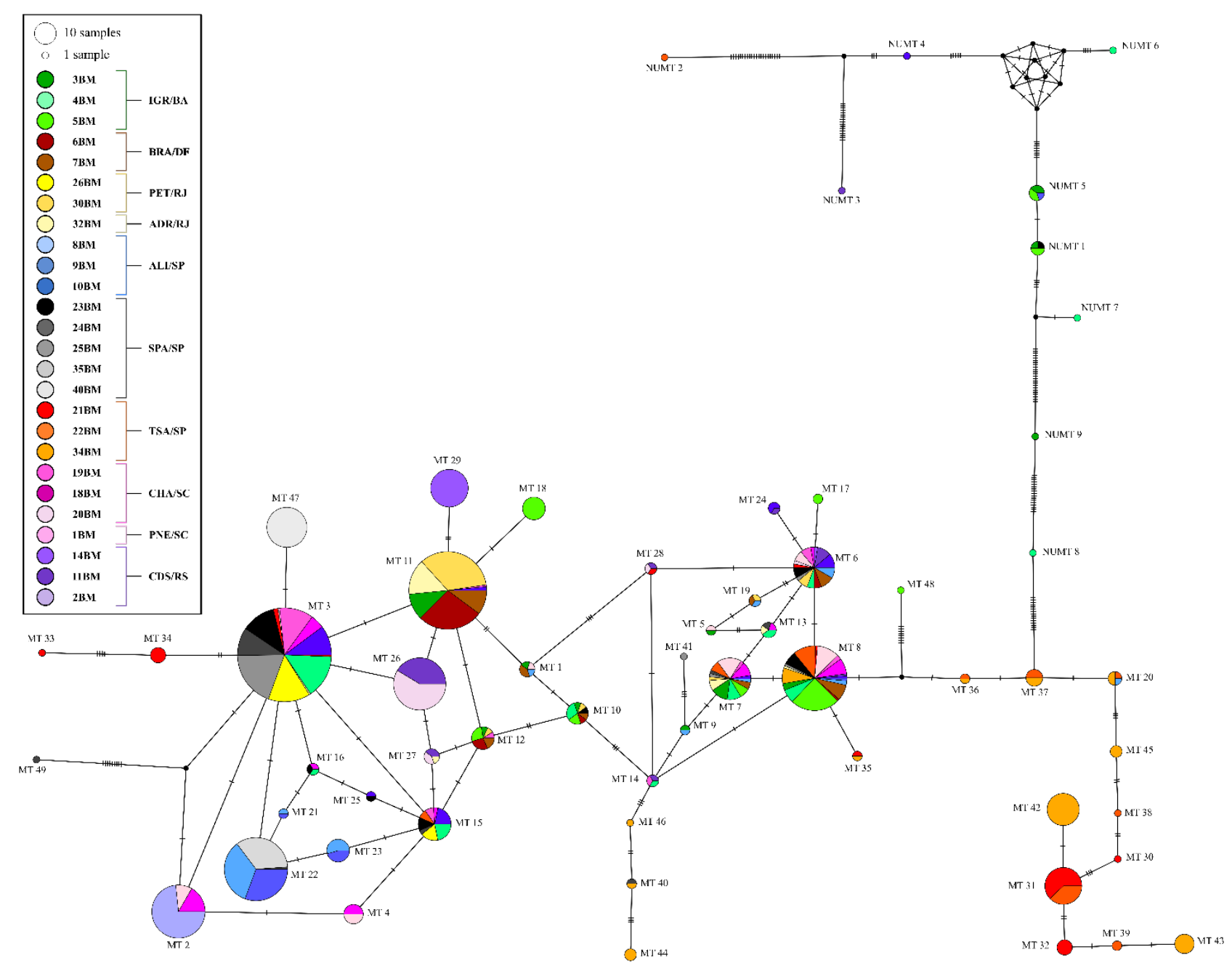

Figura 2.4. Rede de relação entre os haplótipos mitocondriais e NUMTs obtidos a partir do sequenciamento dos insertos clonados dos 26 indivíduos de B. morio. Cada cor representa um indivíduo. Cada círculo representa um haplótipo distinto e o seu tamanho é proporcional à sua frequência. As barras transversais indicam o número de passos mutacionais entre os haplótipos. 


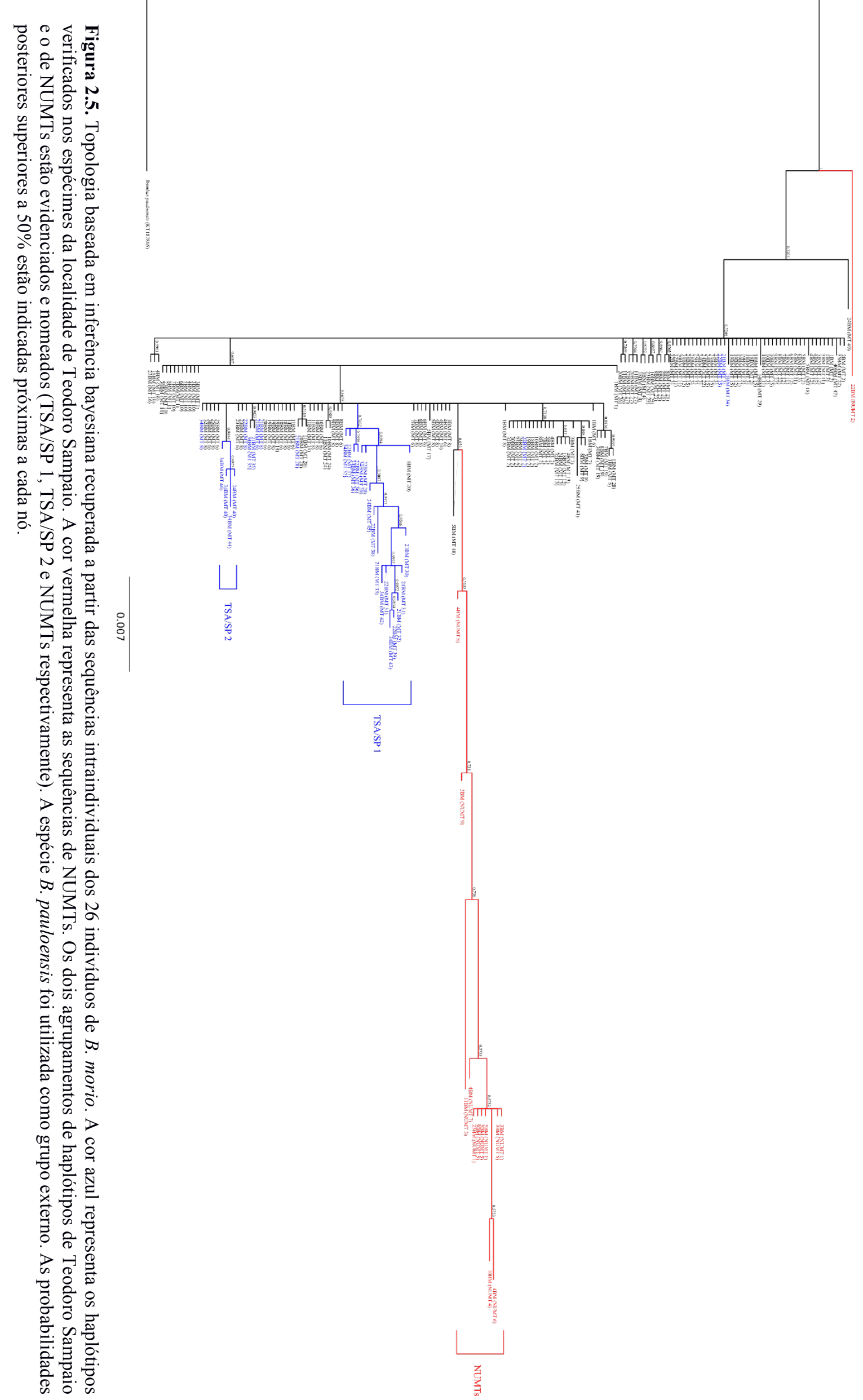




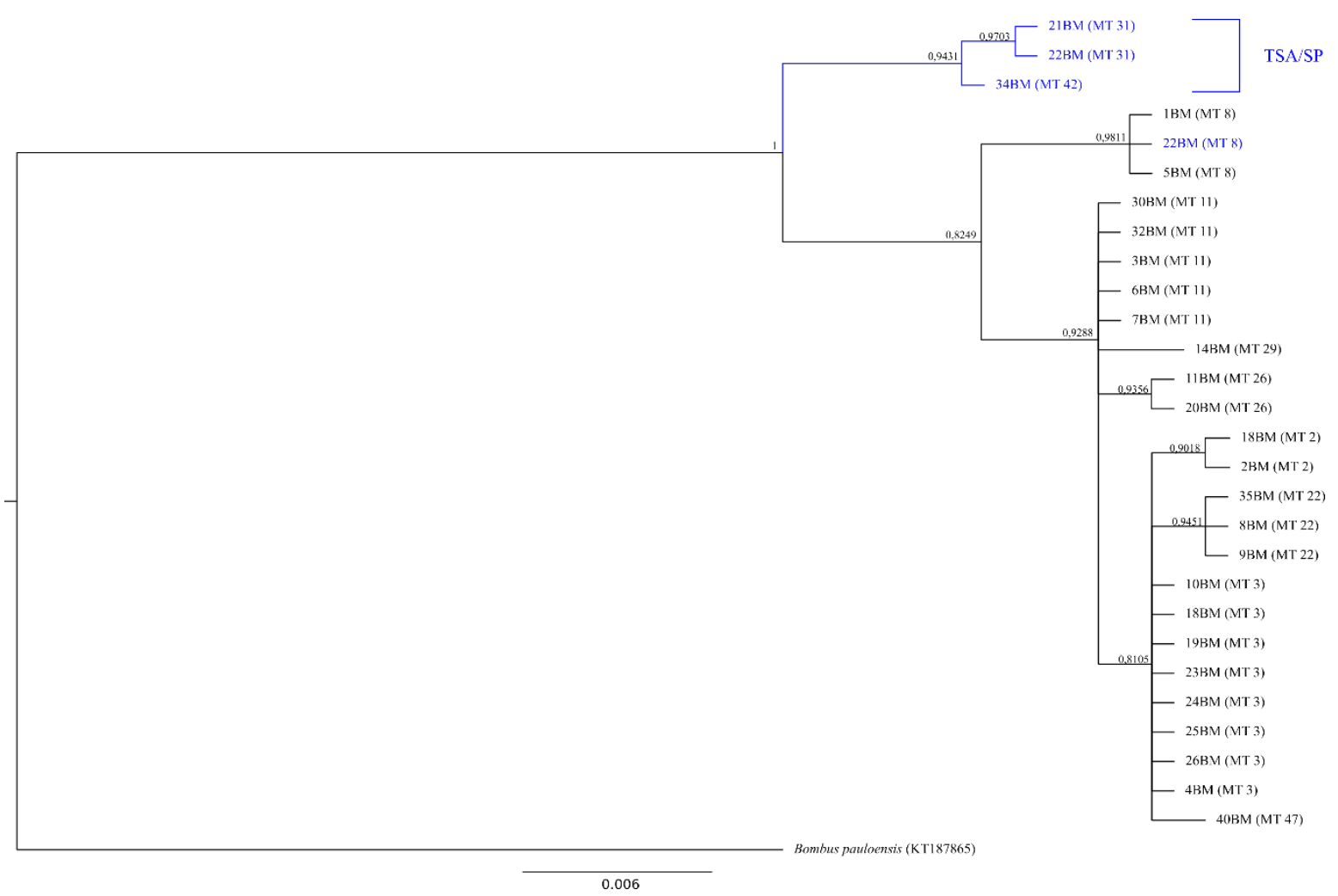

Figura 2.6. Topologia baseada em inferência bayesiana recuperada a partir da sequência do haplótipo mitocondrial mais frequente em cada indivíduo. A espécie B. pauloensis foi utilizada como grupo externo. As probabilidades posteriores superiores a $50 \%$ estão indicadas próximas a cada nó.

\subsubsection{Efeito da variação intraindividual versus interespecífica}

A maior parte das comparações par a par entre os haplótipos intraindividuais apresentaram distâncias inferiores a 2\% (Figura 2.7; Apêndices A e B). Por outro lado, as comparações entre sequências mitocondriais intraindividuais e os NUMTs revelaram valores de distância superiores a $2 \%$ e, em alguns casos ultrapassando 11\%. Essas distâncias foram superiores a maior parte das obtidas em comparações interespecíficas entre espécies do subgênero Thoracobombus, que variaram de 1,2\% (B. applanatus e B. brevivillus) a 14\% (B. excellens e B. applanatus; B. excellens e B. brevivillus). 


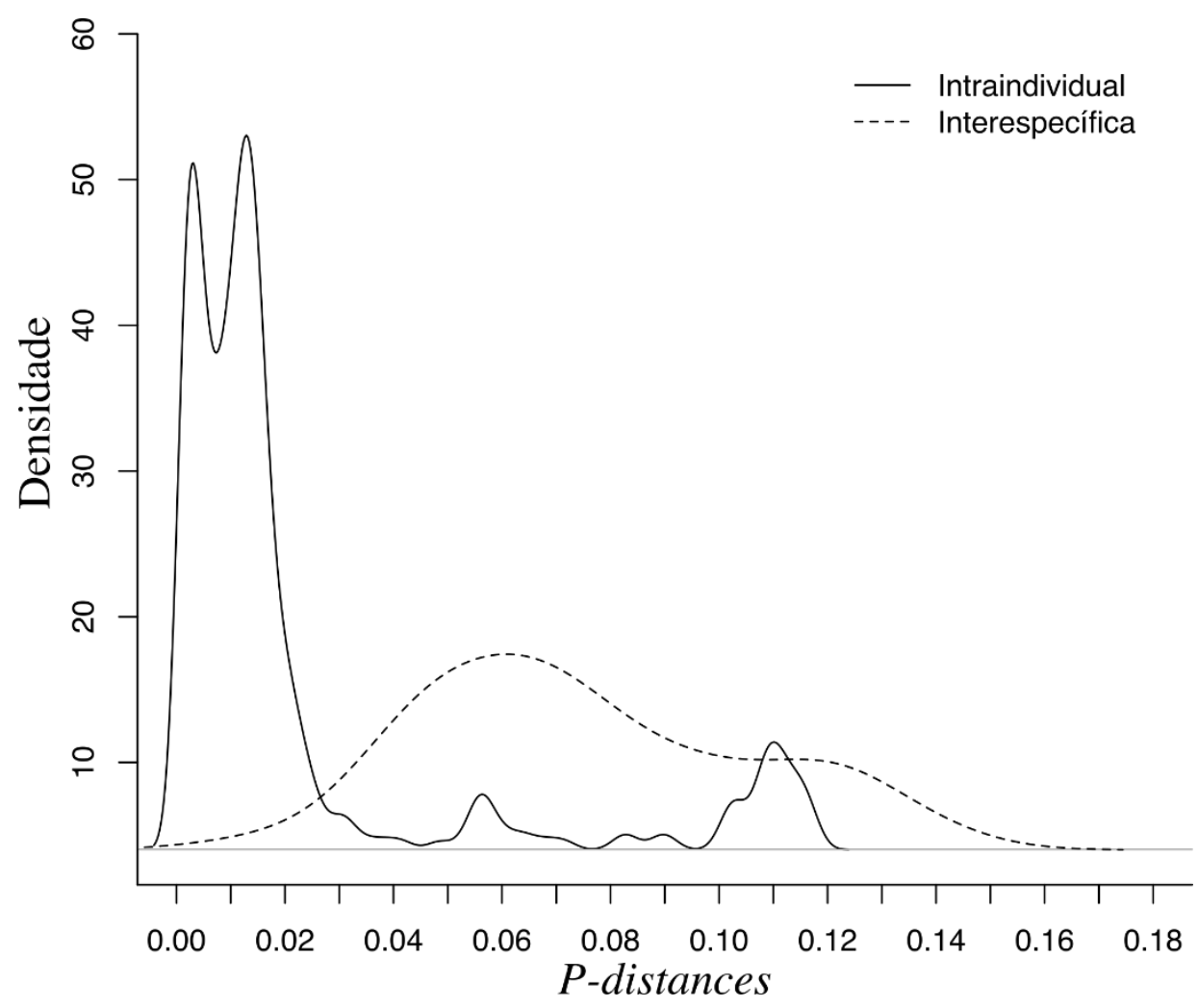

Figura 2.7. Densidade das distribuições dos valores das pairwise p-distances obtidas em comparações intraindividuais (utilizando as sequências obtidas nesse estudo) e interespecíficas (comparações entre sequências de diferentes espécies de Bombus do subgênero Thoracobombus).

\subsection{Discussão}

Os resultados obtidos corroboraram a ocorrência de heteroplasmia descrita por Françoso et al. (2016). O estado heteroplásmico foi verificado na maioria dos espécimes amostrados, independente da sua localidade de origem. Sendo assim, a heteroplasmia parece ser um fenômeno comum em B. morio. Em média, foram recuperados 7 haplótipos heteroplásmicos por indivíduo, alguns diferindo em mais de 8 passos mutacionais entre si, sendo que a maioria das mutações observadas foram sinônimas, ocorrendo na terceira base dos códons.

A quantidade de haplótipos e o número de mutações intraindividuais superaram as expectativas. Sabe-se que em humanos o processo de envelhecimento pode levar ao acúmulo de um grande número de mutações, com baixa frequência, no mtDNA presente nas células somáticas (LIN et al., 2002). No entanto, ainda não é comprovado se o curto ciclo de vida dos insetos oferece tempo suficiente para o acúmulo de muitas mutações em apenas uma geração (BERTHIER et al., 2011). Além disso, muitos dos haplótipos heteroplásmicos encontrados em B. morio foram compartilhados por indivíduos de localidades diferentes, sendo que alguns 
destes haplótipos foram observados em quase todas as localidades. Assim é possível que a heteroplasmia em $B$. morio seja um estado transmitido de forma estável através das gerações.

A manutenção da heteroplasmia ao longo de várias gerações não é algo amplamente aceito, no entanto existem explicações plausíveis para justificar sua ocorrência. A primeira seria por pressão seletiva. Doublet et al. (2008), por exemplo, sugerem que a transmissão estável da heteroplasmia em espécies de isópodes da subordem Oniscidae ocorre devido a seleção, pois nesses organismos a heteroplasmia preserva um polimorfismo mitocondrial necessário para a tradução correta do RNA mensageiro (mRNA). Além disso, alguns autores sugerem que alguns genótipos mitocondriais podem apresentar vantagens seletivas em determinados tecidos, tais como vantagens replicativas ou em relação a funções da cadeia respiratória, enquanto que seriam desvantajosos em outros (JENUTH; PETERSON; SHOUBRIDGE, 1997). Dessa forma a conservação da heteroplasmia ao longo das gerações seria interessante do ponto de vista evolutivo, pois manteria os diferentes genótipos mitocondriais. Outra possível explicação seria a ocorrência de heteroplasmia intramitocondrial como proposto no modelo faithful nucleoid (JACOBS; LEHTINEN; SPELBRINK, 2000). Nesse modelo a transmissão estável da heteroplasmia seria decorrente da replicação fidedigna dos nucleoides mitocondriais, que são complexos formados por várias moléculas de mtDNA em associação com proteínas (CHEN; BUTOW, 2005). Assim a heteroplasmia seria mantida porque as variantes de mtDNA seriam herdadas como uma unidade ao longo das gerações.

Os nossos dados indicam que a heteroplasmia apresenta grande potencial para gerar incongruências em trabalhos populacionais e filogeográficos. O exemplo mais claro observado foram os indivíduos da localidade de Teodoro Sampaio. A maioria dos haplótipos desses espécimes apresentaram em média 1,8\% de divergência em relação ao restante da amostragem, não sendo incomum comparações com divergência superior a $2 \%$ entre as sequências. Trabalhos anteriores também observaram grande divergência entre os haplótipos mitocondriais de indivíduos de Teodoro Sampaio e dos obtidos de espécimes do restante da distribuição de $B$. morio. No trabalho de Francisco et al. (2016) a divergência estimada entre as sequências de Teodoro Sampaio e de outras populações foi de 2,065-2,454\%, enquanto que no trabalho de Françoso et al. (2016) a divergência média encontrada entre as sequências de Teodoro Sampaio e o restante das localidades foi de $1,73 \%$. Adicionalmente, no presente trabalho, foram observados haplótipos heteroplásmicos compartilhados entre indivíduos de Teodoro Sampaio e de outras localidades. Também foram recuperados haplótipos que parecem ser intermediários entre esses haplótipos compartilhados e os haplótipos de Teodoro Sampaio mais divergentes. Isso resultou em uma topologia onde os haplótipos dos indivíduos de Teodoro Sampaio estão 
no mesmo grupo dos haplótipos dos espécimes das demais localidades, contrastando com a topologia obtida por Françoso et al. (2016), onde os indivíduos de Teodoro Sampaio foram incluídos em um clado separado. Por sua vez, quando foram analisados somente os haplótipos mais frequentes para cada indivíduo, a topologia recuperada foi semelhante à obtida por Françoso et al. (2016), com exceção de um dos haplótipos do indivíduo 22 BM, coletado em Teodoro Sampaio, que agrupou com os haplótipos mais frequentes de espécimes de outras localidades. A utilização do haplótipo mais frequente como o haplótipo mitocondrial "real" do indivíduo em estudos evolutivos é coerente, mas somente em um contexto onde se considera a heteroplasmia como resultado do acúmulo de mutações no mtDNA de células somáticas ao longo da vida de um indivíduo. No entanto, em um cenário onde a heteroplasmia é herdada, e principalmente no caso de heteroplasmia estável, torna-se impossível a atribuição de um único haplótipo mitocondrial a um indivíduo. Além disso a escolha do haplótipo mais frequente pode estar condicionada a um viés de amostragem, já que a frequência de haplótipos heteroplásmicos pode variar de acordo com o tecido (KIRCHES et al., 2001; MAGNACCA; BROWN, 2010; KRJUTŠKOV et al., 2014; LI et al., 2015; NAUE et al., 2015), e muitas vezes apenas uma parte do espécime é utilizada para a realização da extração do mtDNA.

A detecção da heteroplasmia ocorre principalmente através da visualização de picos duplos nos eletroferogramas (TANG; HUANG, 2010; VOLLMER et al., 2011). No entanto, muitas vezes as mutações individuais são muito raras para serem identificadas no sequenciamento direto (LIN et al., 2002). Além disso, picos duplos podem ser interpretados como erros de sequenciamento, e é possível que nesses casos a heteroplasmia seja ignorada. $\mathrm{O}$ sequenciamento do produto de PCR de amplificações distintas de um mesmo indivíduo não revelou consistência na posição dos picos duplos, mesmo nos sítios onde a heteroplasmia foi confirmada após a clonagem. Esse resultado demonstra que a ausência de picos duplos não exclui a possibilidade de heteroplasmia. Mesmo quando a posição dos picos duplos nos eletroferogramas analisados foi consistente com a presença de heteroplasmia, não foi possível determinar qual era o haplótipo heteroplásmico mais frequente, pois os picos mais altos variaram entre os eletroferogramas. Assim, apesar de produzirem evidências da presença de heteroplasmia, a análise de picos duplos em eletroferogramas se mostrou questionável na investigação desse estado, sendo para isso indicado a utilização da técnica de clonagem. Novas metodologias envolvendo sequenciamento em larga escala (high throughput sequencing) vêm sendo utilizadas para identificar variantes heteroplásmicas (GUO et al., 2013; YE et al., 2014; ALBAYRAK et al., 2016) e também podem representar alternativas interessantes nesse sentido. 
Os resultados também evidenciaram a presença de NUMTs em B. morio. No entanto, foram recuperadas poucas dessas sequências em relação a sequências mitocondriais, provavelmente devido a metodologia utilizada neste trabalho. O método de extração utilizado (FRANÇOSO; GOMES; ARIAS, 2015) promove um enriquecimento de mtDNA, e portanto, não seria esperado a amplificação de sequências de origem nuclear. Além disso, o DNA foi extraído das pernas das abelhas, compostas basicamente por tecido muscular, rico em mitocôndrias, facilitando assim a extração do genoma organelar. Essa abordagem foi empregada porque o foco inicial deste trabalho era a investigação da heteroplasmia. A utilização de tecidos ricos em mitocôndrias para extração de DNA e protocolos de enriquecimento/isolamento de mtDNA são sugeridos na literatura como formas de evitar a contaminação por NUMTs (SONG et al., 2008; BUHAY, 2009; WOLFF et al., 2012). Infelizmente não tivemos sucesso total na eliminação do nuDNA em algumas amostras, embora a metodologia aqui aplicada tenha sido eficiente em outro estudo (FRANÇOSO; GOMES; ARIAS, 2015).

Nas comparações intraindividuais entre sequências mitocondriais e NUMTs foram recuperados valores de distância que variaram de $2 \%$ a mais de $12 \%$, mostrando que os NUMTs podem representar obstáculos na identificação de espécies através do DNA barcoding. Uma das premissas do DNA barcoding é a adoção de um valor limite para a identificação de espécies, e geralmente valores de divergência superiores a 2\% são utilizados como o limite para separar espécies (HEBERT et al., 2003; RATNASINGHAM; HEBERT, 2007; WARD; HANNER; HEBERT, 2009). Além disso, em estudos populacionais os níveis de divergência exibidos pelos NUMTs poderiam levar a inferências incorretas em relação a diferenciação entre populações (BERTHIER et al., 2011).

A maioria das sequências de NUMTs foi facilmente identificada, pois exibiram características associadas a esse tipo de sequência, como mutações em sítios aleatórios e códons de parada prematuros (BENSASSON et al., 2001; CALVIGNAC et al., 2011). Por outro lado, algumas sequências classificadas como NUMTs não apresentaram essas características. Essas sequências, embora muito similares a sequências mitocondriais, foram agrupadas com os demais NUMTs na análise bayesiana, e em geral apresentaram um número maior de mutações não sinônimas que a maioria das sequências mitocondriais. Além disso, duas sequências classificadas como mitocondriais (MT 48, MT 49), também foram agrupadas com os NUMTs. Provavelmente essas sequências podem se tratar de NUMTs recentemente transferidos para o genoma nuclear. Quando a transferência é recente, os NUMTs tendem a ser idênticos ou muito similares às sequências do mtDNA, uma vez que não houve tempo suficiente para o acúmulo 
de novas mutações (GOIOS; CARVALHO; AMORIM, 2009; TRIANT; DEWOODY, 2009; MIRALDO et al., 2012). São esses casos que representam os maiores desafios para a estratégia do DNA barcoding, uma vez que se torna difícil a distinção entre NUMTs e sequências mitocondriais. Ainda existe a possibilidade da amplificação preferencial desses NUMTs, principalmente quando são utilizados primers universais (BENESH et al., 2006; IBARGUCHI; FRIESEN; LOUGHEED, 2006), aumentando a chance de identificações incorretas. Isso ocorre porque os NUMTs evoluem mais lentamente e podem ser mais conservados que sequências mitocondriais atuais, e dessa forma, apresentar maior complementaridade com primers nãoespecíficos que sua contraparte mitocondrial (ZHANG; HEWITT, 1996a).

Por fim, tanto a heteroplasmia quanto os NUMTs mostraram grande potencial em interferir em abordagens onde sequências do mtDNA são amplamente empregadas como marcadores. Entretanto, apesar dos impactos negativos que os NUMTs oferecem nos estudos evolutivos e populacionais, a sua identificação pode ser favorecida pela presença de indels. Estes levam à mudança do quadro de leitura e ocorrência de códons de parada prematuros (BENSASSON et al., 2001; FREY; FREY, 2004). Análises levando em consideração os padrões de substituição também podem auxiliar na identificação de NUMTs, uma vez que a maior parte das mutações no mtDNA ocorre na terceira posição dos códons, diferentemente dos NUMTs, que acumulam mutações independentemente da posição no códon (CALVIGNAC et al., 2011). Além disso, na literatura são sugeridas algumas estratégias para minimizar a contaminação por NUMTs, sendo que as mais recorrentes envolvem a extração de material genético de tecidos ricos em mitocôndrias, a escolha de protocolos de enriquecimento ou isolamento de mtDNA e a utilização de primers espécie-específicos (ZHANG; HEWITT, 1996a; IBARGUCHI; FRIESEN; LOUGHEED, 2006; SONG et al., 2008; MOULTON; SONG; WHITING, 2010; CALVIGNAC et al., 2011). A heteroplasmia, por sua vez, se revela como um desafio mais complexo, uma vez que nem sempre é detectada sem investigações mais aprofundadas, e mesmo quando sua presença é identificada a escolha de um haplótipo único para um indivíduo pode ser algo muito difícil. Dessa forma a utilização de sequências do mtDNA deve ser utilizada de forma cautelosa, e indícios de heteroplasmia não devem ser ignorados. Nesses casos investigações mais minuciosas devem ser realizadas, a fim de verificar o quão frequente a heteroplasmia é dentro do grupo estudado, e quais as possíveis consequências produzidas pela presença desse estado. Além disso, assim como já observado para NUMTs (JENSEN-SEAMAN et al., 2004; HASSANIN et al., 2010), é possível que resultados obtidos em trabalhos já publicados tenham sido influenciados pela presença de heteroplasmia. Isso sugere a necessidade de revisão de dados gerados em trabalhos anteriores 
que utilizaram sequências do mtDNA como marcadores moleculares, assim como a discussão acerca da confiabilidade oferecida pelo uso dessas sequências em estudos futuros.

\subsection{Referências Bibliográficas}

ALBAYRAK, L.; KHANIPOV, K.; PIMENOVA, M.; GOLOVKO, G.; ROJAS, M.; PAVLIDIS, I.; CHUMAKOV, S.; AGUILAR, G.; CHÁVEZ, A.; WIDGER, W. R.; FOFANOV, Y. The ability of human nuclear DNA to cause false positive low-abundance heteroplasmy calls varies across the mitochondrial genome. BMC Genomics, v. 17, n. 1, p. 1017, 2016.

ANDRUS, R. The molecular evolution of nuclear mitochondrial pseudogenes (NUMTS) in the solitary bee, Colletes stepheni, with notes on pollination biology and geographic distribution. 2003. 98 f. Dissertação (Mestrado) - Department of Biology, Utah State University, Logan, Utah, USA. 2003.

BAEZA, J. A.; FUENTES, M. S. Exploring phylogenetic informativeness and nuclear copies of mitochondrial DNA (Numts) in three commonly used mitochondrial genes: Mitochondrial phylogeny of peppermint, cleaner, and semi-terrestrial shrimps (Caridea: Lysmata, Exhippolysmata. Zoological Journal of the Linnean Society, v. 168, n. 4, p. 699-722, 2013.

BANDELT, H. J.; FORSTER, P.; ROHL, A. Median-joining networks for inferring intraspecific phylogenies. Molecular Biology and Evolution, v. 16, n. 1, p. 37-48, 1999.

BENDALL, K. E.; MACAULAY, V. A.; SYKES, B. C. Variable levels of a heteroplasmic point mutation in individual hair roots. The American Journal of Human Genetics, v. 61, n. 6, p. 1303-1308, 1997.

BENESH, D. P.; HASU, T.; SUOMALAINEN, L. R.; VALTONEN, E. T.; TIIROLA, M. Reliability of mitochondrial DNA in an acanthocephalan: The problem of pseudogenes. International Journal for Parasitology, v. 36, n. 2, p. 247-254, 2006.

BENSASSON, D.; ZHANG, D.-X.; HARTL, D. L.; HEWITT, G. M. Mitochondrial pseudogenes: Evolution's misplaced witnesses. Trends in Ecology and Evolution, v. 16, n. 6, p. 314-321, 2001.

BERTHEAU, C.; SCHULER, H.; KRUMBÖCK, S.; ARTHOFER, W.; STAUFFER, C. Hit or miss in phylogeographic analyses: The case of the cryptic NUMTs. Molecular Ecology Resources, v. 11, p. 1056-1059, 2011.

BERTHIER, K.; CHAPUIS, M. P.; MOOSAVI, S. M.; TOHIDI-ESFAHANI, D.; SWORD, G. A. Nuclear insertions and heteroplasmy of mitochondrial DNA as two sources of intraindividual genomic variation in grasshoppers. Systematic Entomology, v. 36, n. 2, p. 285-299, 2011.

BOURSOT, P.; YONEKAWA, H.; BONHOMME, F. Heteroplasmy in mice with deletion of a large coding region of mitochondrial DNA. Molecular Biology and Evolution, v. 4, n. 1, p. 46-55, 1987. 
BRANDSTÄTTER, A.; NIEDERSTÄTTER, H.; PARSON, W. Monitoring the inheritance of heteroplasmy by computer-assisted detection of mixed basecalls in the entire human mitochondrial DNA control region. International Journal of Legal Medicine, v. 118, n. 1, p. 47-54, 2004.

BUHAY, J. E. "COI-like" sequences are becoming problematic in molecular systematic and DNA barcoding studies. Journal of Crustacean Biology, v. 29, n. 1, p. 96-110, 2009.

CALVIGNAC, S.; KONECNY, L.; MALARD, F.; DOUADY, C. J. Preventing the pollution of mitochondrial datasets with nuclear mitochondrial paralogs (numts). Mitochondrion, v. 11, n. 2, p. 246-254, 2011.

CHEN, X. J.; BUTOW, R. A. The organization and inheritance of the mitochondrial genome. Nature Reviews Genetics, v. 6, n. 11, p. 815-825, 2005.

COMAS, D.; PÄÄBO, S.; BERTRANPETIT, J. Heteroplasmy in the control region of human mitochondrial DNA. Genome Research, v. 5, n. 1, p. 89-90, 1995.

CRISTIANO, M. P.; FERNANDES-SALOMÃO, T. M.; YOTOKO, K. S. C. Nuclear mitochondrial DNA: An Achilles' heel of molecular systematics, phylogenetics, and phylogeographic studies of stingless bees. Apidologie, v. 43, n. 5, p. 527-538, 2012.

DARRIBA, D.; TABOADA, G. L.; DOALLO, R.; POSADA, D. jModelTest 2: more models, new heuristics and parallel computing. Nature Methods, v. 9, n. 8, p. 772-772, 2012.

DIMAURO, S.; SCHON, E. A. Mitochondrial DNA mutations in human disease. American Journal of Medical Genetics, v. 106, n. 1, p. 18-26, 2001.

DOUBLET, V.; SOUTY-GROSSET, C.; BOUCHON, D.; CORDAUX, R.; MARCADÉ, I. A thirty million year-old inherited heteroplasmy. PLoS ONE, v. 3, n. 8, p. e2938, 2008. doi: 10.1371/journal.pone.0002938

DUDU, A.; GEORGESCU, S. E.; BERREBI, P.; COSTACHE, M. Site heteroplasmy in the mitochondrial cytochrome $b$ gene of the sterlet sturgeon Acipenser ruthenus. Genetics and Molecular Biology, v. 35, n. 4, p. 886-891, 2012.

EICHMANN, C.; PARSON, W. Molecular characterization of the canine mitochondrial DNA control region for forensic applications. International Journal of Legal Medicine, v. 121, n. 5, p. 411-416, 2007.

EWING, B.; HILLIER, L.; WENDL, M. C.; GREEN, P. Base-calling of automated sequencer traces using phred. I. Accuracy assessment. Genome Research, v. 8, n. 3, p. 175-185, 1998.

FRANCISCO, F. O.; SANTIAGO, L. R.; MIZUSAWA, Y. M.; OLDROYD, B. P.; ARIAS, M. C. Genetic structure of island and mainland populations of a Neotropical bumble bee species. Journal of Insect Conservation, v. 20, n. 3, p. 383-394, 2016.

FRANÇOSO, E.; ARIAS, M. C. Cytochrome c oxidase I primers for corbiculate bees: DNA barcode and mini-barcode. Molecular Ecology Resources, v. 13, n. 5, p. 844-850, 2013. 
FRANÇOSO, E.; GOMES, F.; ARIAS, M. C. A protocol for isolating insect mitochondrial genomes: a case study of NUMT in Melipona flavolineata (Hymenoptera: Apidae). Mitochondrial DNA, v. 27, n. 4, p. 1-4, 2015.

FRANÇOSO, E.; ZUNTINI, A. R.; CARNAVAL, A. C.; ARIAS, M. C. Comparative phylogeography in the Atlantic forest and Brazilian savannas: pleistocene fluctuations and dispersal shape spatial patterns in two bumblebees. BMC Evolutionary Biology, v. 16, n. 1, p. 267, 2016. doi: 10.1186/s12862-016-0803-0

FREY, J. E.; FREY, B. Origin of intra-individual variation in PCR-amplified mitochondrial cytochrome oxidase I of Thrips tabaci (Thysanoptera: Thripidae): mitochondrial heteroplasmy or nuclear integration? Hereditas, v. 140, n. 2, p. 92-98, 2004.

GALTIER, N.; NABHOLZ, B.; GLÉMIN, S.; HURST, G. D. D. Mitochondrial DNA as a marker of molecular diversity: a reappraisal. Molecular Ecology, v. 18, n. 22, p. 4541-4550, 2009.

GELLISSEN, G.; BRADFIELD, J. Y.; WHITE, B. N.; WYATT, G. R. Mitochondrial DNA sequences in the nuclear genome of a locust. Nature, v. 301, n. 5901, p. 631-634, 1983.

GOIOS, A.; CARVALHO, A.; AMORIM, A. Identifying NUMT contamination in mtDNA analyses. Forensic Science International: Genetics Supplement Series, v. 2, n. 1, p. 278$280,2009$.

GREENBERG, B. D.; NEWBOLD, J. E.; SUGINO, A. Intraspecific nucleotide mitochondrial DNA sequence variability surrounding the origin of replication in human. Gene, v. 21, p. 3349, 1983.

GUO, Y.; LI, J.; LI, C.-I.; SHYR, Y.; SAMUELS, D. C. MitoSeek: extracting mitochondria information and performing high-throughput mitochondria sequencing analysis. Bioinformatics, v. 29, n. 9, p. 1210-1211, 2013.

HADLER, H. I.; DIMITRIJEVIC, B.; MAHALINGAM, R. Mitochondrial DNA and nuclear DNA from normal rat liver have a common sequence. Proceedings of the National Academy of Sciences, v. 80, n. 21, p. 6495-6499, 1983.

HARAN, J.; KOUTROUMPA, F.; MAGNOUX, E.; ROQUES, A.; ROUX, G. Ghost mtDNA haplotypes generated by fortuitous NUMTs can deeply disturb infra-specific genetic diversity and phylogeographic pattern. Journal of Zoological Systematics and Evolutionary Research, v. 53, n. 2, p. 109-115, 2015.

HASSANIN, A.; BONILlO, C.; NGUYEN, B. X.; CRUAUD, C. Comparisons between mitochondrial genomes of domestic goat ( Capra hircus ) reveal the presence of numts and multiple sequencing errors. Mitochondrial DNA, v. 21, n. 3-4, p. 68-76, 2010.

HAUSWIRTH, W. W.; LAIPIS, P. J. Mitochondrial DNA polymorphism in a maternal lineage of Holstein cows. Proceedings of the National Academy of Sciences, v. 79, n. 15, p. 4686$4690,1982$.

HAZKANI-COVO, E. Mitochondrial insertions into primate nuclear genomes suggest the use 
of numts as a tool for phylogeny. Molecular Biology and Evolution, v. 26, n. 10, p. 2175$2179,2009$.

HAZKANI-COVO, E.; ZELLER, R. M.; MARTIN, W. Molecular Poltergeists: Mitochondrial DNA Copies (numts) in Sequenced Nuclear Genomes. PLoS Genetics, v. 6, n. 2, p. e1000834, 2010. doi: 10.1371/journal.pgen.1000834

HEBERT, P. D. N.; CYWINSKA, A.; BALL, S. L.; DEWAARD, J. R. Biological identifications through DNA barcodes. Proceedings of the Royal Society B: Biological Sciences, v. 270, n. 1512, p. 313-321, 2003.

HOLT, I. J.; HARDING, A. E.; MORGAN-HUGHES, J. A. Deletions of muscle mitochondrial DNA in patients with mitochondrial myopathies. Nature, v. 331, n. 6158, p. 717-719, 1988.

IBARGUCHI, G.; FRIESEN, V. L.; LOUGHEED, S. C. Defeating numts : Semi-pure mitochondrial DNA from eggs and simple purification methods for field-collected wildlife tissues. Genome, v. 49, n. 11, p. 1438-1450, 2006.

IRWIN, J. A.; SAUNIER, J. L.; NIEDERSTÄTTER, H.; STROUSS, K. M.; STURK, K. A.; DIEGOLI, T. M.; BRANDSTÄTTER, A.; PARSON, W.; PARSONS, T. J. Investigation of heteroplasmy in the human mitochondrial DNA control region: A synthesis of observations from more than 5000 global population samples. Journal of Molecular Evolution, v. 68, n. 5 , p. 516-527, 2009.

IVANOV, P. L.; WADHAMS, M. J.; ROBY, R. K.; HOLLAND, M. M.; WEEDN, V. W.; PARSONS, T. J. Mitochondrial DNA sequence heteroplasmy in the Grand Duke of Russia Georgij Romanov establishes the authenticity of the remains of Tsar Nicholas II. Nature Genetics, v. 12, n. 4, p. 417-420, 1996.

JACOBS, H. T.; LEHTINEN, S. K.; SPELBRINK, J. N. No sex please, we're mitochondria: a hypothesis on the somatic unit of inheritance of mammalian mtDNA. BioEssays, v. 22, n. 6, p. $564-572,2000$.

JACOBS, H. T.; POSAKONY, J. W.; GRULA, J. W.; ROBERTS, J. W.; XIN, J.-H.; BRITTEN, R. J.; DAVIDSON, E. H. Mitochondrial DNA sequences in the nuclear genome of Strongylocentrotus pupuratus. Journal of Molecular Biology, v. 165, n. 4, p. 609-632, 1983.

JANSEN, R. P. S.; DE BOER, K. The bottleneck: mitochondrial imperatives in oogenesis and ovarian follicular fate. Molecular and Cellular Endocrinology, v. 145, n. 1-2, p. 81-88, 1998.

JENSEN-SEAMAN, M. I.; SARMIENTO, E. E.; DEINARD, A. S.; KIDD, K. K. Nuclear integrations of mitochondrial DNA in gorillas. American Journal of Primatology, v. 63, n. 3, p. 139-147, 2004.

JENUTH, J. P.; PETERSON, A. C.; SHOUBRIDGE, E. A. Tissue-specific selection for different mtDNA genotypes in heteroplasmic mice. Nature genetics, v. 16, n. 1, p. 93-95, 1997.

KEARSE, M.; MOIR, R.; WILSON, A.; STONES-HAVAS, S.; CHEUNG, M.; STURROCK, S.; BUXTON, S.; COOPER, A.; MARKOWITZ, S.; DURAN, C.; THIERER, T.; ASHTON, 
B.; MEINTJES, P.; DRUMMOND, A. Geneious Basic: An integrated and extendable desktop software platform for the organization and analysis of sequence data. Bioinformatics, v. 28, n. 12, p. 1647-1649, 2012.

KIRCHES, E.; MICHAEL, M.; WARICH-KIRCHES, M.; SCHNEIDER, T.; WEIS, S.; KRAUSE, G.; MAWRIN, C.; DIETZMANN, K. Heterogeneous tissue distribution of a mitochondrial DNA polymorphism in heteroplasmic subjects without mitochondrial disorders. Journal of Medical Genetics, v. 38, n. 5, p. 312-317, 2001.

KMIEC, B.; WOLOSZYNSKA, M.; JANSKA, H. Heteroplasmy as a common state of mitochondrial genetic information in plants and animals. Current Genetics, v. 50, n. 3, p. 149$159,2006$.

KRESS, W. J.; GARCÍA-ROBLEDO, C.; URIARTE, M.; ERICKSON, D. L. DNA barcodes for ecology, evolution, and conservation. Trends in Ecology and Evolution, v. 30, n. 1, p. 25$35,2015$.

KRJUTŠKOV, K.; KOLTŠINA, M.; GRAND, K.; VÕSA, U.; SAUK, M.; TÕNISSON, N.; SALUMETS, A. Tissue-specific mitochondrial heteroplasmy at position 16,093 within the same individual. Current Genetics, v. 60, n. 1, p. 11-16, 2014.

KUMAR, P.; HENIKOFF, S.; NG, P. C. Predicting the effects of coding non-synonymous variants on protein function using the SIFT algorithm. Nature Protocols, v. 4, n. 8, p. 1073$1081,2009$.

LECHER, P.; BEZIAT, F.; ALZIARI, S. Tissular distribution of heteroplasmy and ultrastructural studies of mitochondria from a Drosophila subobscura mitochondrial deletion mutant. Biology of the Cell, v. 80, n. 1, p. 25-33, 1994.

LEIGH, J. W.; BRYANT, D. Popart: full-feature software for haplotype network construction. Methods in Ecology and Evolution, v. 6, n. 9, p. 1110-1116, 2015.

LI, M.; SCHRÖDER, R.; NI, S.; MADEA, B.; STONEKING, M. Extensive tissue-related and allele-related mtDNA heteroplasmy suggests positive selection for somatic mutations. Proceedings of the National Academy of Sciences, v. 112, n. 8, p. 2491-2496, 2015.

LIBRADO, P.; ROZAS, J. DnaSP v5: a software for comprehensive analysis of DNA polymorphism data. Bioinformatics, v. 25, n. 11, p. 1451-1452, 2009.

LIGHTOWLERS, R. N.; CHINNERY, P. F.; TURNBULL, D. M.; HOWELL, N. Mammalian mitochondrial genetics: heredity, heteroplasmy and disease. Trends in Genetics, v. 13, n. 11, p. $450-455,1997$.

LIN, M. T.; SIMON, D. K.; AHN, C. H.; KIM, L. M.; BEAL, M. F. High aggregate burden of somatic mtDNA point mutations in aging and Alzheimer's disease brain. Human Molecular Genetics, v. 11, n. 2, p. 133-145, 2002.

LOPEZ, J. V.; YUHKI, N.; MASUDA, R.; MODI, W.; O'BRIEN, S. J. Numt, a recent transfer and tandem amplification of mitochondrial DNA to the nuclear genome of the domestic cat. Journal of Molecular Evolution, v. 39, n. 2, p. 174-190, 1994. 
MAGNACCA, K. N.; BROWN, M. J. F. Tissue segregation of mitochondrial haplotypes in heteroplasmic Hawaiian bees: Implications for DNA barcoding. Molecular Ecology Resources, v. 10, n. 1, p. 60-68, 2010.

MAGNACCA, K. N.; BROWN, M. J. F. DNA barcoding a regional fauna: Irish solitary bees. Molecular Ecology Resources, v. 12, n. 6, p. 990-998, 2012.

MAGNACCA, K. N.; DANFORTH, B. N. Evolution and biogeography of native Hawaiian Hylaeus bees (Hymenoptera: Colletidae). Cladistics, v. 22, n. 5, p. 393-411, 2006.

MIRALDO, A.; HEWITT, G. M.; DEAR, P. H.; PAULO, O. S.; EMERSON, B. C. Numts help to reconstruct the demographic history of the ocellated lizard (Lacerta lepida) in a secondary contact zone. Molecular Ecology, v. 21, n. 4, p. 1005-1018, 2012.

MORAES, C. T.; SCHON, E. A.; DIMAURO, S.; MIRANDA, A. F. Heteroplasmy of mitochondrial genomes in clonal cultures from patients with Kearns-Sayre syndrome. Biochemical and Biophysical Research Communications, v. 160, n. 2, p. 765-771, 1989.

MOULTON, M. J.; SONG, H.; WHITING, M. F. Assessing the effects of primer specificity on eliminating numt coamplification in DNA barcoding: A case study from Orthoptera (Arthropoda: Insecta). Molecular Ecology Resources, v. 10, n. 4, p. 615-627, 2010.

NAUE, J.; HÖRER, S.; SÄNGER, T.; STROBL, C.; HATZER-GRUBWIESER, P.; PARSON, W.; LUTZ-BONENGEL, S. Evidence for frequent and tissue-specific sequence heteroplasmy in human mitochondrial DNA. Mitochondrion, v. 20, p. 82-94, 2015.

OLSON, L. E.; YODER, A. D. Using Secondary Structure to Identify Ribosomal Numts : Cautionary Examples from the Human Genome. Molecular Biology and Evolution, v. 19, n. 1, p. 93-100, 2002.

PAMILO, P.; VILJAKAINEN, L.; VIHAVAINEN, A. Exceptionally high density of NUMTs in the honeybee genome. Molecular Biology and Evolution, v. 24, n. 6, p. 1340-1346, 2007.

PARADIS, E. pegas: an $\mathrm{R}$ package for population genetics with an integrated-modular approach. Bioinformatics, v. 26, n. 3, p. 419-420, 2010.

PARADIS, E.; CLAUDE, J.; STRIMMER, K. APE: Analyses of phylogenetics and evolution in R language. Bioinformatics, v. 20, n. 2, p. 289-290, 2004.

PERNA, N. T.; KOCHER, T. D. Mitochondrial DNA: Molecular fossils in the nucleus. Current Biology, v. 6, n. 2, p. 128-129, fev. 1996.

PETIT, N.; TOURAILlE, S.; DEBISE, R.; MOREL, F.; RENOUX, M.; LECHER, P.; ALZIARI, S. Developmental changes in heteroplasmy level and mitochondrial gene expression in a Drosophila subobscura mitochondrial deletion mutant. Current Genetics, v. 33, n. 5, p. 330-339, 1998.

R CORE TEAM. R: A Language and Environment for Statistical Computing. Vienna, Austria, 2016. Disponível em: < http://www.r-project.org/>. 
RATNASINGHAM, S.; HEBERT, P. D. N. BOLD: The Barcode of Life Data System (www.barcodinglife.org). Molecular Ecology Notes, v. 7, p. 355-364, 2007.

RICHLY, E.; LEISTER, D. NUMTs in sequenced eukaryotic genomes. Molecular Biology and Evolution, v. 21, n. 6, p. 1081-1084, 2004.

RONQUIST, F.; TESLENKO, M.; VAN DER MARK, P.; AYRES, D. L.; DARLING, A.; HÖHNA, S.; LARGET, B.; LIU, L.; SUCHARD, M. A.; HUELSENBECK, J. P. Mrbayes 3.2: Efficient bayesian phylogenetic inference and model choice across a large model space. Systematic Biology, v. 61, n. 3, p. 539-542, 2012.

RÖTIG, A.; CORMIER, V.; BLANCHE, S.; BONNEFONT, J. P.; LEDEIST, F.; ROMERO, N.; SCHMITZ, J.; RUSTIN, P.; FISCHER, A.; SAUDUBRAY, J. M. Pearson's marrowpancreas syndrome. A multisystem mitochondrial disorder in infancy. Journal of Clinical Investigation, v. 86, n. 5, p. 1601-1608, 1990.

RUBINOFF, D.; CAMERON, S.; WILL, K. A genomic perspective on the shortcomings of mitochondrial DNA for "barcoding" identification. Journal of Heredity, v. 97, n. 6, p. 581594, 2006.

RUIZ, C.; DE J. MAY-ITZÁ, W.; QUEZADA-EUÁN, J. J. G.; DE LA RÚA, P. Presence of nuclear copies of mitochondrial origin (NUMTs) in two related species of stingless bee genus Melipona (Hymenoptera: Meliponini). Journal of Zoological Systematics and Evolutionary Research, v. 51, n. 2, p. 107-113, 2013.

SACHADYN, P.; ZHANG, X. M.; CLARK, L. D.; NAVIAUX, R. K.; HEBER-KATZ, E. Naturally occurring mitochondrial DNA heteroplasmy in the MRL mouse. Mitochondrion, v. 8, n. 5-6, p. 358-366, 2008.

SAMBROOK, J.; FRITSCH, E. F.; MANIATIS, T. Molecular cloning: A laboratory manual. 2. ed. New York: Cold Spring Harbor Laboratory Press, 1989. v. 3

SANTOS, C.; SIERRA, B.; ÁlVAREZ, L.; RAMOS, A.; FERNÁNDEZ, E.; NOGUÉS, R.; ALUJA, M. P. Frequency and pattern of heteroplasmy in the control region of human mitochondrial DNA. Journal of Molecular Evolution, v. 67, n. 2, p. 191-200, 2008.

SHARPLEY, M. S.; MARCINIAK, C.; ECKEL-MAHAN, K.; MCMANUS, M.; CRIMI, M.; WAYMIRE, K.; LIN, C. S.; MASUBUCHI, S.; FRIEND, N.; KOIKE, M.; CHALKIA, D.; MACGREGOR, G.; SASSONE-CORSI, P.; WALLACE, D. C. Heteroplasmy of mouse mtDNA is genetically unstable and results in altered behavior and cognition. Cell, v. 151, n. 2, p. 333-343, 2012.

SHOUBRIDGE, E. A. Mitochondrial DNA segregation in the developing embryo. Human Reproduction, v. 15, n. suppl 2, p. 229-234, 2000.

SIMON, C.; FRATI, F.; BECKENBACH, A.; CRESPI, B.; LIU, H.; FLOOK, P. Evolution, weighting, and phylogenetic utility of mitochondrial gene sequences and a compilation of conserved polymerase chain reaction primers. Annals of the Entomological Society of America, v. 87, n. 6, p. 651-701, 1994. 
SOLIGNAC, M.; MONNEROT, M.; MOUNOLOU, J. C. Mitochondrial DNA heteroplasmy in Drosophila mauritiana. Proceedings of the National Academy of Sciences, v. 80, n. 22, p. 6942-6946, 1983.

SONG, H.; BUHAY, J. E.; WHITING, M. F.; CRANDALL, K. A. Many species in one: DNA barcoding overestimates the number of species when nuclear mitochondrial pseudogenes are coamplified. Proceedings of the National Academy of Sciences, v. 105, n. 36, p. 1348613491, 2008.

SONGRAM, O.; SITTIPRANEED, S.; KLINBUNGA, S. Mitochondrial DNA diversity and genetic differentiation of the honeybee (Apis cerana) in Thailand. Biochemical Genetics, v. 44, n. 5-6, p. 256-269, 2006.

SORENSON, M. D.; QUINN, T. W. Numts: A Challenge for Avian Systematics and Population. The Auk, v. 115, n. 1, p. 214-221, 1998.

STEWART, J. B.; CHINNERY, P. F. The dynamics of mitochondrial DNA heteroplasmy: implications for human health and disease. Nature Reviews Genetics, v. 16, n. 9, p. 530-542, 2015.

TANG, S.; HUANG, T. Characterization of mitochondrial DNA heteroplasmy using a parallel sequencing system. BioTechniques, v. 48, n. 4, p. 287-296, 2010.

TRIANT, D. A.; DEWOODY, J. A. Demography and phylogenetic utility of numt pseudogenes in the southern red-backed vole (Myodes gapperi). Journal of Mammalogy, v. 90, n. 3, p. 561$570,2009$.

TSANG, W. Y.; LEMIRE, B. D. Stable heteroplasmy but differential inheritance of a large mitochondrial DNA deletion in nematodes. Biochemistry and Cell Biology, v. 80, n. 5, p. 645654, 2002.

TSUZUKI, T.; NOMIYAMA, H.; SETOYAMA, C.; MAEDA, S.; SHIMADA, K. Presence of mitochondrial-DNA-like sequences in the human nuclear DNA. Gene, v. 25, n. 2-3, p. 223229, 1983.

VAN DER KUYL, A. C.; KUIKEN, C. L.; DEKKER, J. T.; PERIZONIUS, W. R.; GOUDSMIT, J. Nuclear counterparts of the cytoplasmic mitochondrial 12S rRNA gene: a problem of ancient DNA and molecular phylogenies. Journal of Molecular Evolution, v. 40, n. 6, p. 652-657, 1995.

VOLLMER, N. L.; VIRICEL, A.; WILCOX, L.; MOORE, K. M.; ROSEL, P. E. The occurrence of mtDNA heteroplasmy in multiple cetacean species. Current Genetics, v. 57, n. 2, p. 115-131, 2011.

VOLZ-LINGENHOHL, A.; SOLIGNAC, M.; SPERLICH, D. Stable heteroplasmy for a largescale deletion in the coding region of Drosophila subobscura mitochondrial DNA. Proceedings of the National Academy of Sciences, v. 89, n. 23, p. 11528-11532, 1992.

WARD, R. D.; HANNER, R.; HEBERT, P. D. N. The campaign to DNA barcode all fishes, FISH-BOL. Journal of Fish Biology, v. 74, n. 2, p. 329-356, fev. 2009. 
WHITE, D. J.; WOLFF, J. N.; PIERSON, M.; GEMMELL, N. J. Revealing the hidden complexities of mtDNA inheritance. Molecular Ecology, v. 17, n. 23, p. 4925-4942, 2008.

WILLIAMS, P. Bumblebees of the world. Disponível em: $<$ http://www.nhm.ac.uk/researchcuration/research/projects/bombus/index.html>. Acesso em: 15 maio. 2017.

WOLFF, J. N.; SHEARMAN, D. C. A.; BROOKS, R. C.; BALLARD, J. W. O. Selective enrichment and sequencing of whole mitochondrial genomes in the presence of nuclear encoded mitochondrial pseudogenes (Numts). PLoS ONE, v. 7, n. 5, p. e37142, 2012. doi: 10.1371/journal.pone.0037142

YATES, C. M.; FILIPPIS, I.; KELLEY, L. A.; STERNBERG, M. J. E. SuSPect: enhanced prediction of single amino acid variant (SAV) phenotype using network features. Journal of Molecular Biology, v. 426, n. 14, p. 2692-2701, 2014.

YE, F.; SAMUELS, D. C.; CLARK, T.; GUO, Y. High-throughput sequencing in mitochondrial DNA research. Mitochondrion, v. 17, p. 157-163, 2014.

ZHANG, D.-X.; HEWITT, G. M. Nuclear integrations: challenges for mitochondrial DNA markers. Trends in Ecology \& Evolution, v. 11, n. 6, p. 247-251, 1996a.

ZHANG, D.-X.; HEWITT, G. M. Highly conserved nuclear copies of the mitochondrial control region in the desert locust Schistocerca gregaria: some implications for population studies. Molecular Ecology, v. 5, n. 2, p. 295-300, 1996 b.

ZHANG, Z.; SCHWARTZ, S.; WAGNER, L.; MILLER, W. A greedy algorithm for aligning DNA sequences. Journal of Computational Biology, v. 7, n. 1-2, p. 203-214, 2000. 


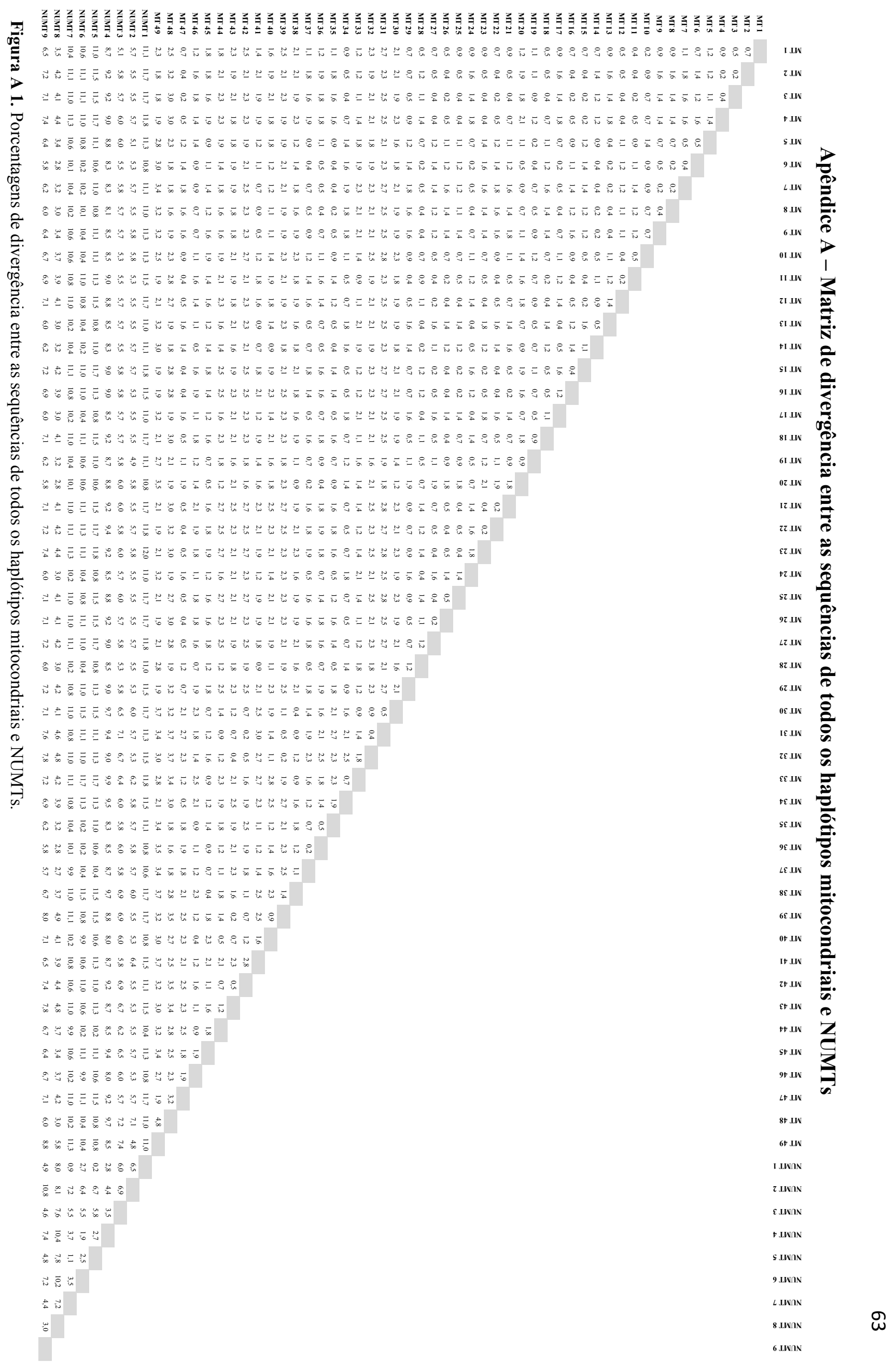


Apêndice B - Matrizes de divergência entre as sequências intraindividuais

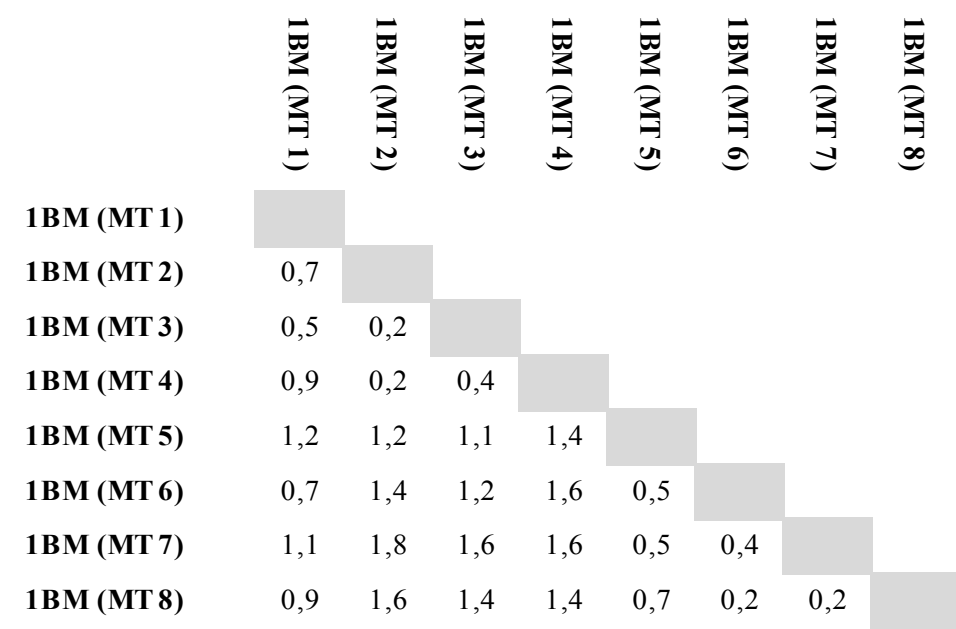

Figura B 1. Porcentagens de divergência entre as sequências do indivíduo 1 BM.

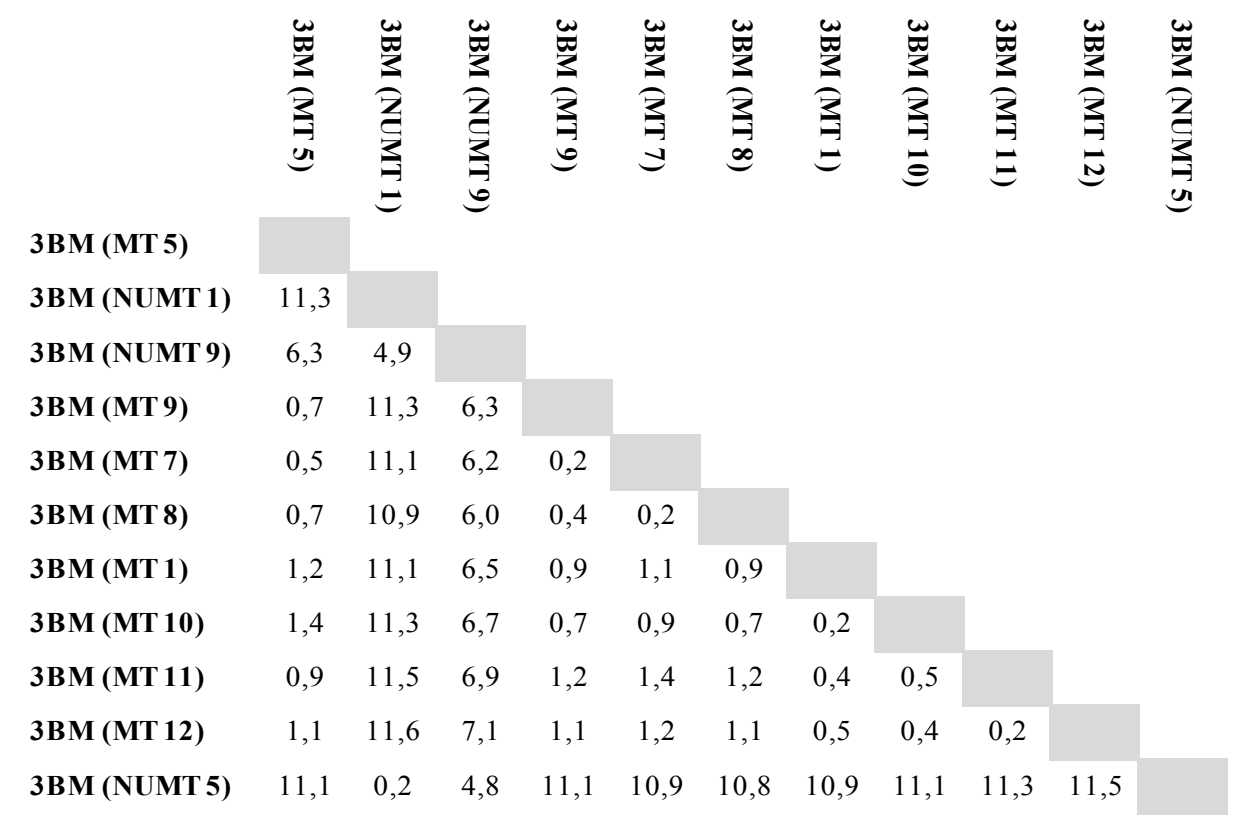

Figura B 2. Porcentagens de divergência entre as sequências do indivíduo 3 BM. 
4BM (MT 6)

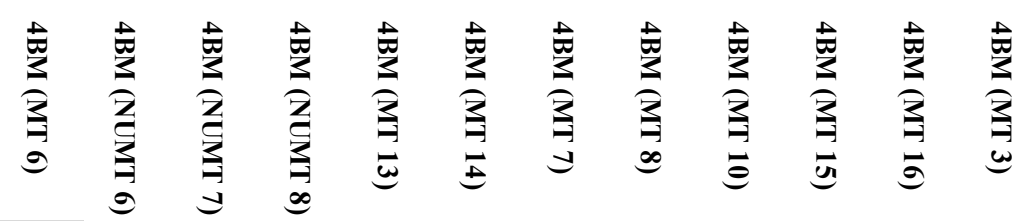

4BM (NUMT 6) $\quad 10,2$

4BM (NUMT 7) $\quad 10,1 \quad 3,5$

4BM (NUMT 8) $\quad 2,8 \quad 10,2 \quad 7,2$

4BM (MT 13) $\quad 0,2 \quad 10,4 \quad 10,2 \quad 3,0$

4BM (MT 14) $\quad 0,4 \quad 10,2 \quad 10,4 \quad 3,2 \quad 0,5$

4BM (MT 7) $\quad 0,4 \quad 10,2 \quad 10,4 \quad 3,2 \quad 0,2 \quad 0,4$

4BM (MT 8) $\quad 0,2 \quad 10,1 \quad 10,2 \quad 3,0 \quad 0,4 \quad 0,2 \quad 0,2$

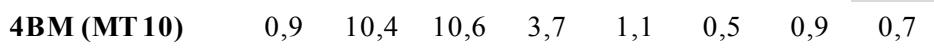

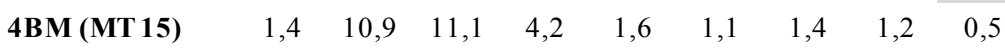

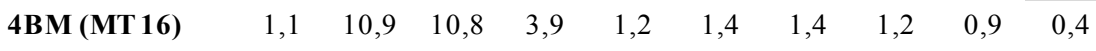

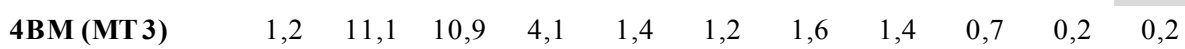

Figura B 3. Porcentagens de divergência entre as sequências do indivíduo 4 BM.

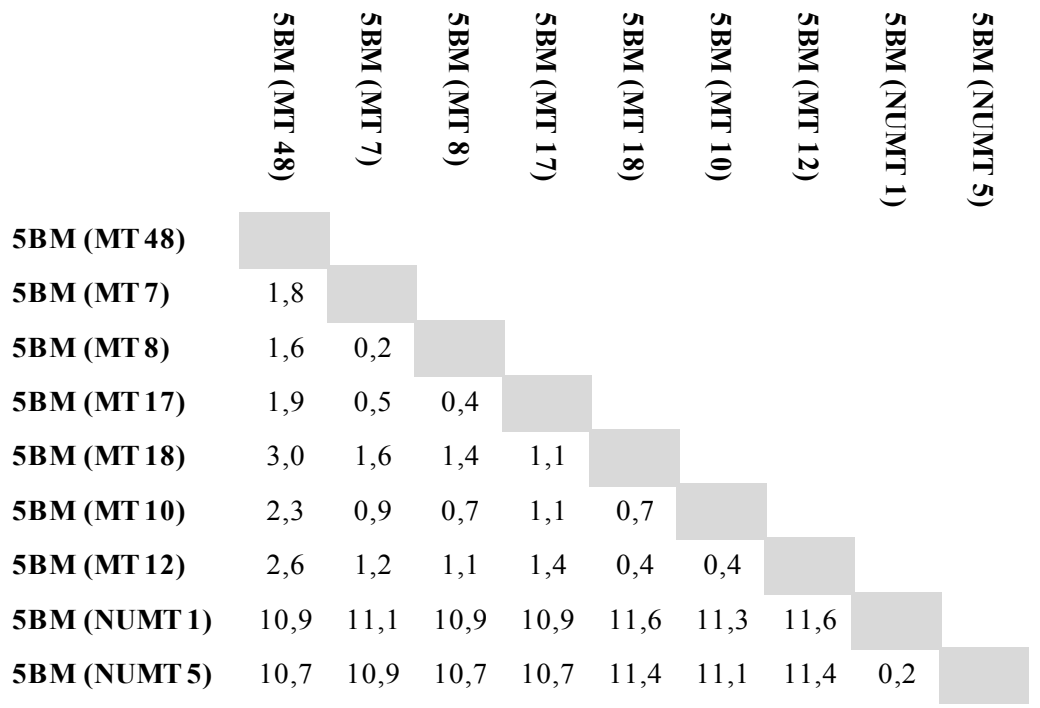

Figura B 4. Porcentagens de divergência entre as sequências do indivíduo 5 BM.

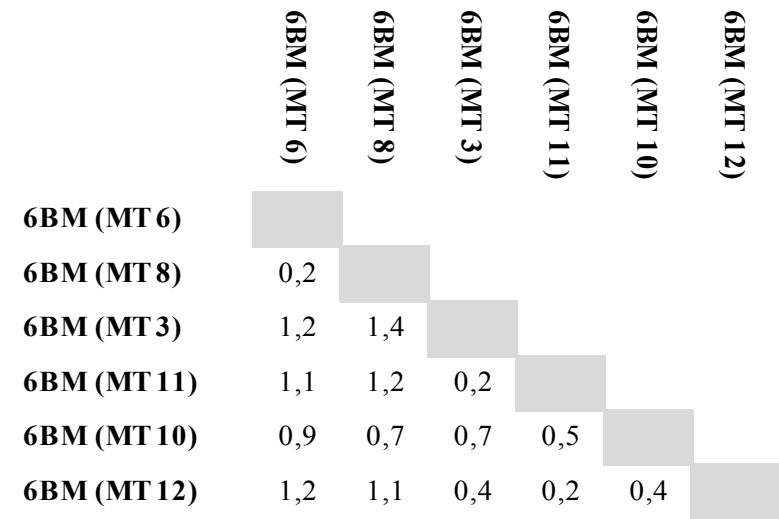

Figura B 5. Porcentagens de divergência entre as sequências do indivíduo 6 BM. 


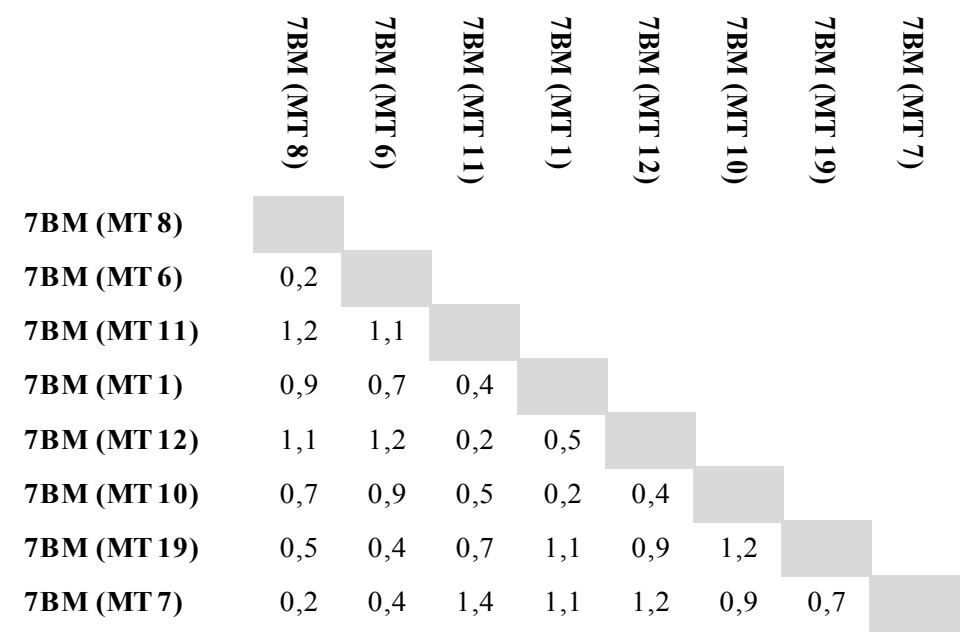

Figura B 6. Porcentagens de divergência entre as sequências do indivíduo 7 BM.

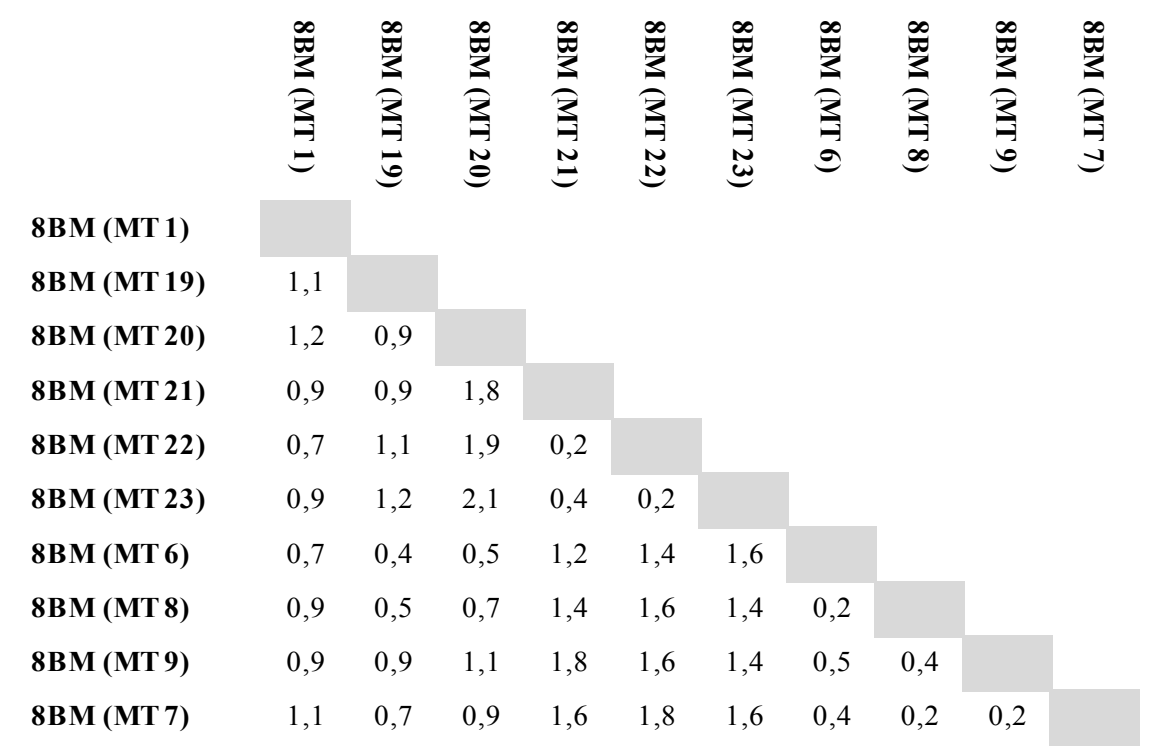

Figura B 7. Porcentagens de divergência entre as sequências do indivíduo 8 BM.

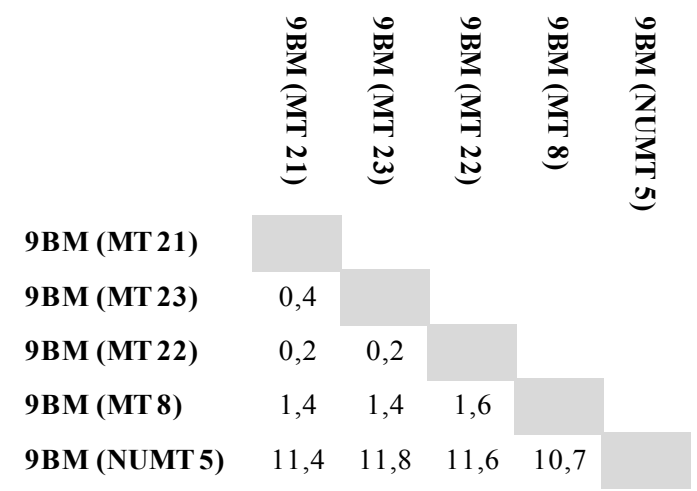

Figura B 8. Porcentagens de divergência entre as sequências do indivíduo 9 BM. 


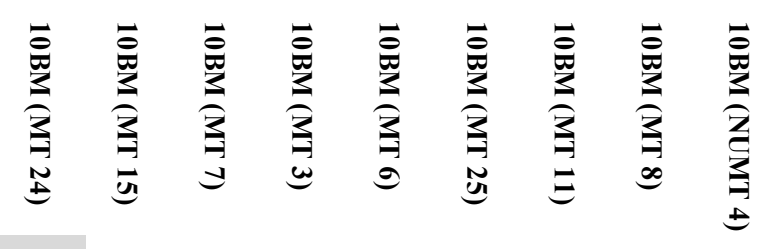

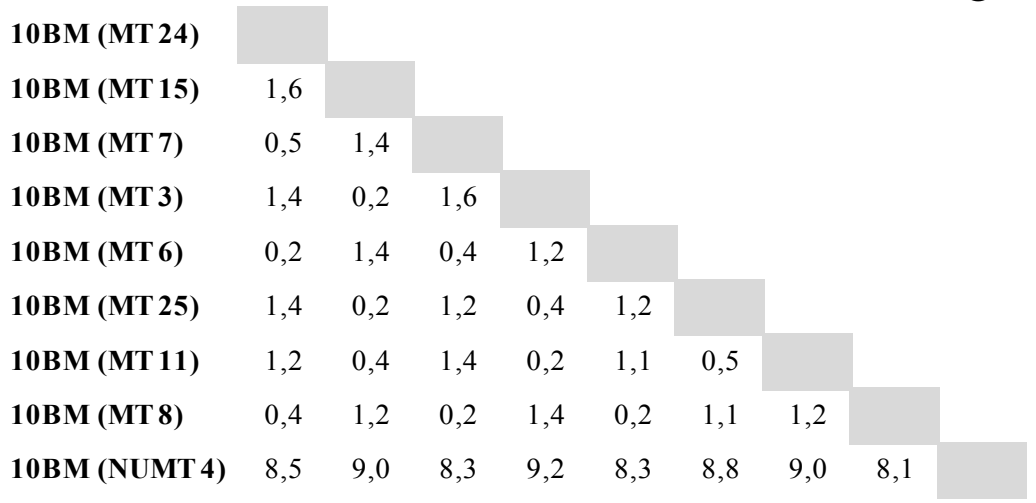

Figura B 9. Porcentagens de divergência entre as sequências do indivíduo 10 BM.

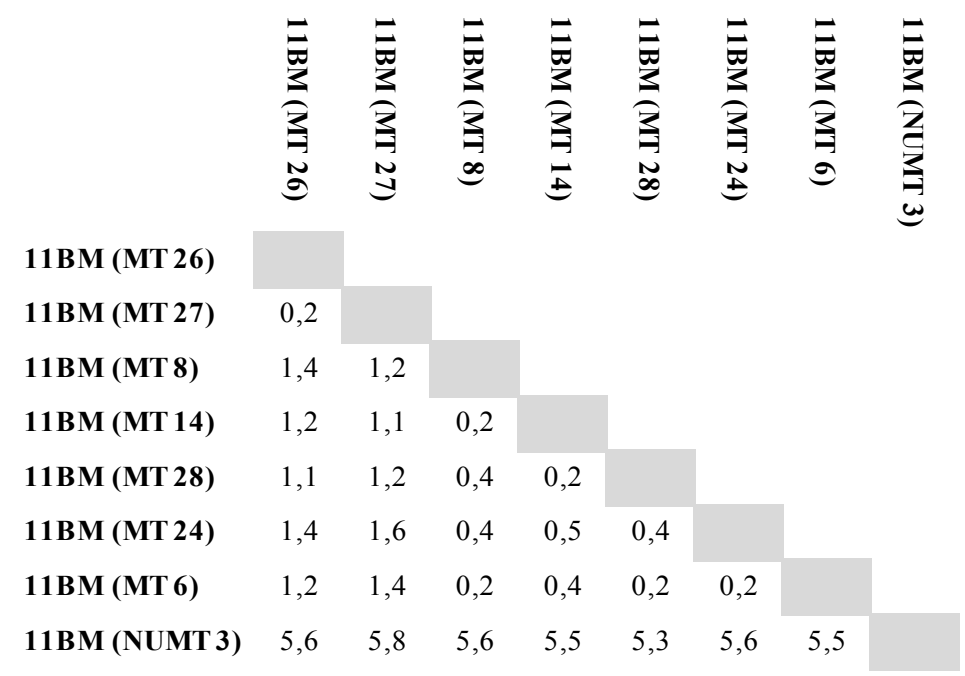

Figura B 10. Porcentagens de divergência entre as sequências do indivíduo 11 BM.

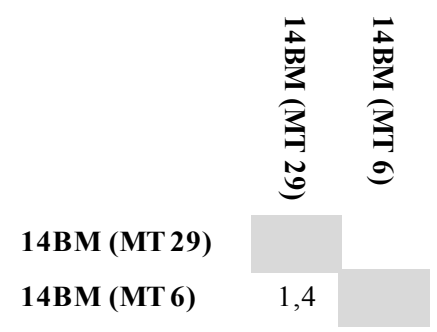

Figura B 11. Porcentagem de divergência entre as sequências do indivíduo 14 BM. 
18BM (MT 4)

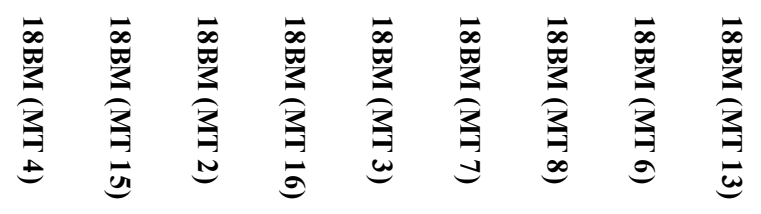

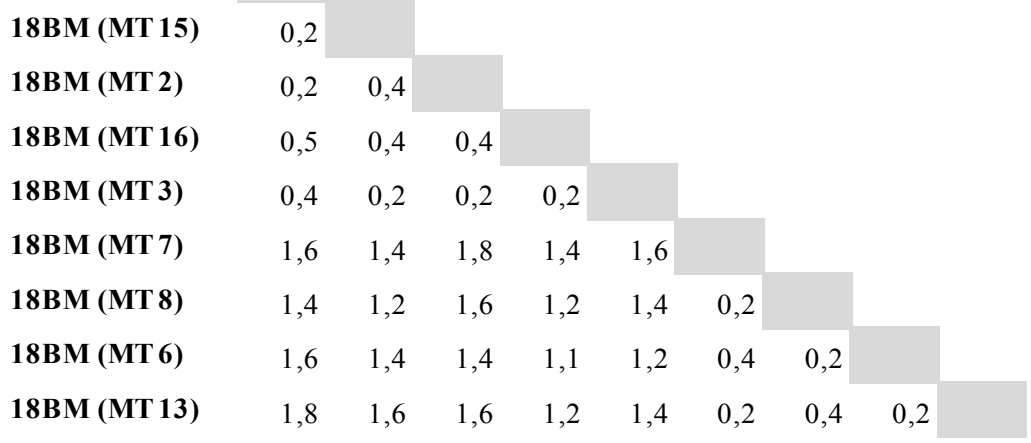

Figura B 12. Porcentagens de divergência entre as sequências do indivíduo 18 BM.

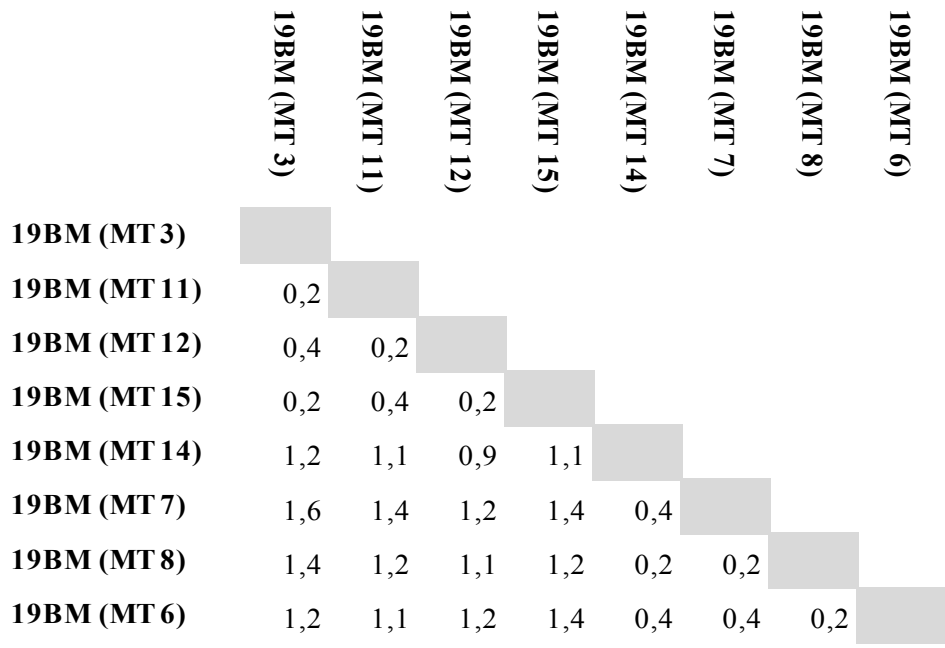

Figura B 13. Porcentagens de divergência entre as sequências do indivíduo 19 BM.

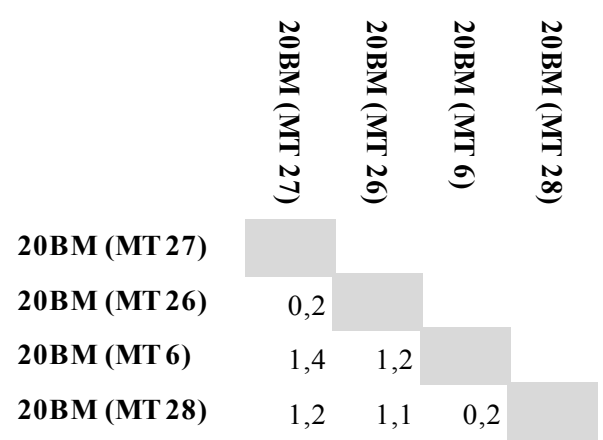

Figura B 14. Porcentagens de divergência entre as sequências do indivíduo 20 BM. 


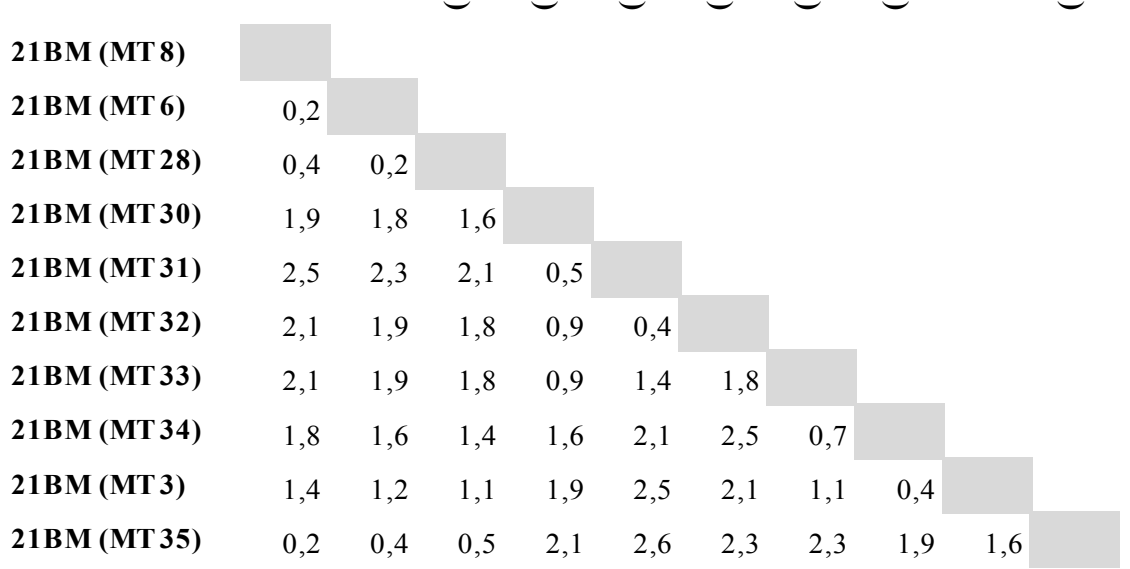

Figura B 15. Porcentagens de divergência entre as sequências do indivíduo 21 BM.

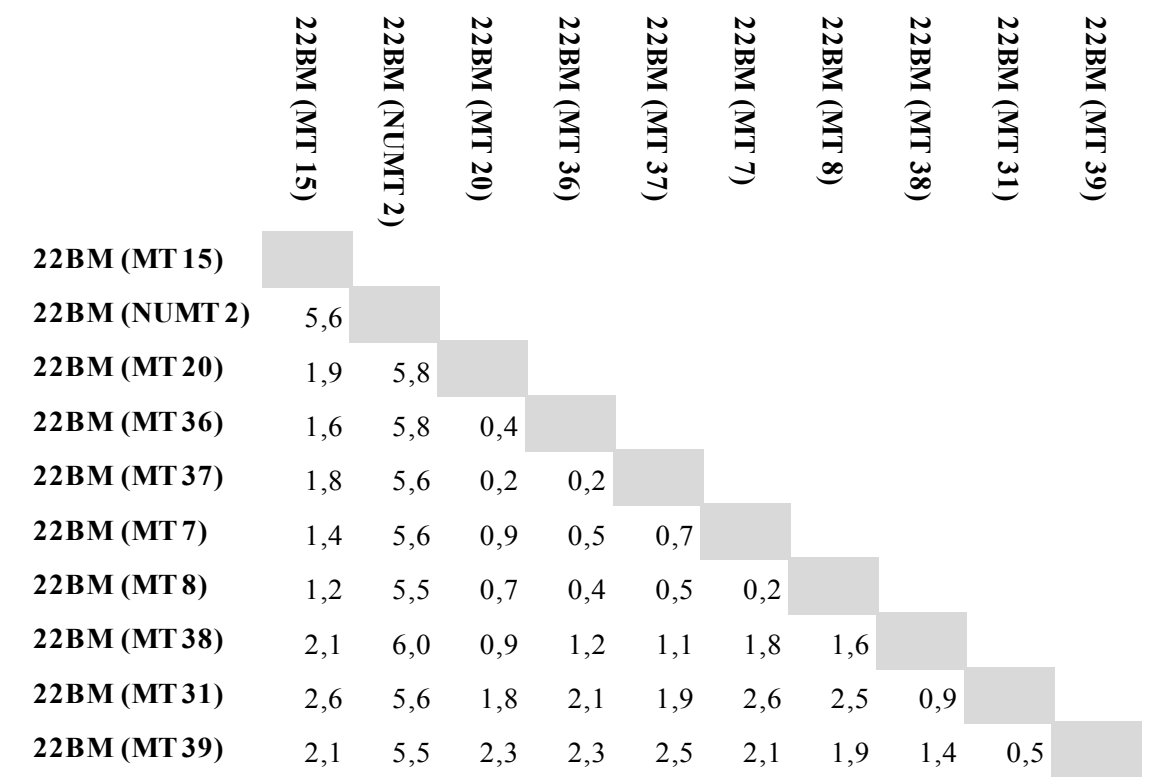

Figura B 16. Porcentagens de divergência entre as sequências do indivíduo 22 BM.

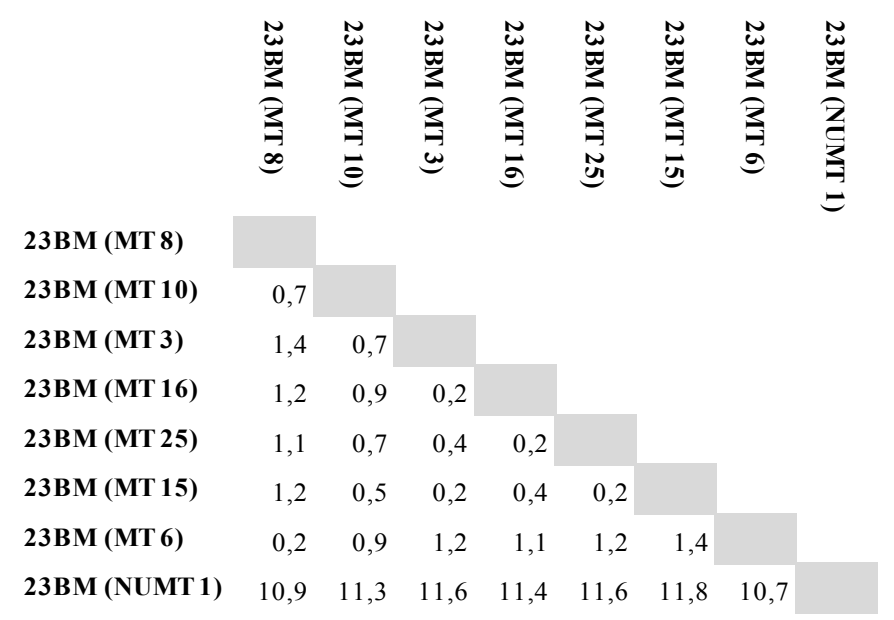

Figura B 17. Porcentagens de divergência entre as sequências do indivíduo 23 BM. 


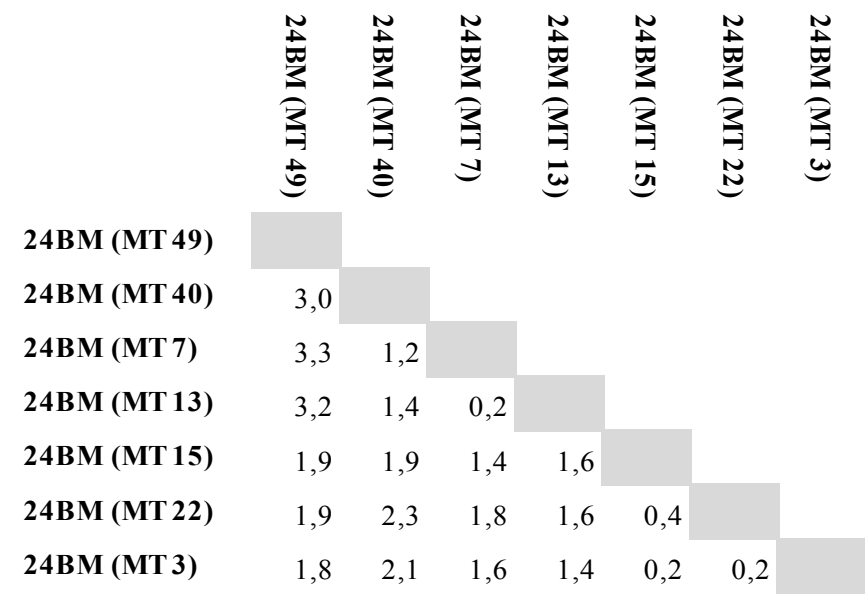

Figura B 18. Porcentagens de divergência entre as sequências do indivíduo 24 BM.

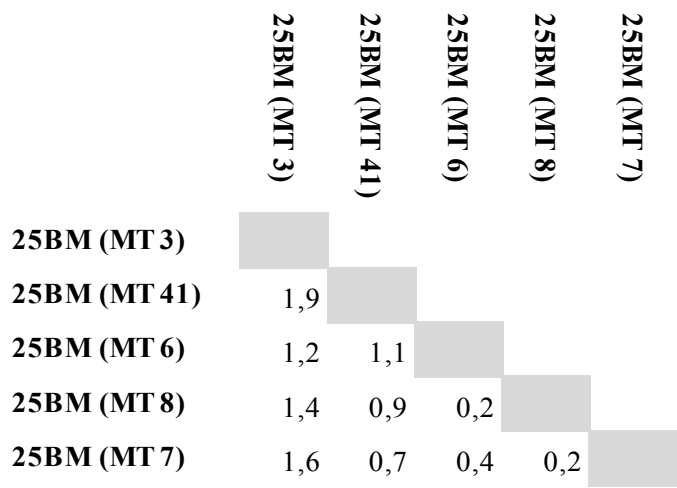

Figura B 19. Porcentagens de divergência entre as sequências do indivíduo 25 BM.

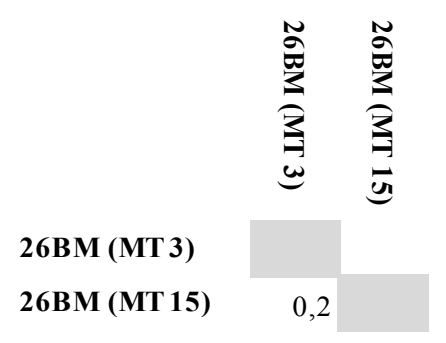

Figura B 20. Porcentagem de divergência entre as sequências do indivíduo 26 BM.

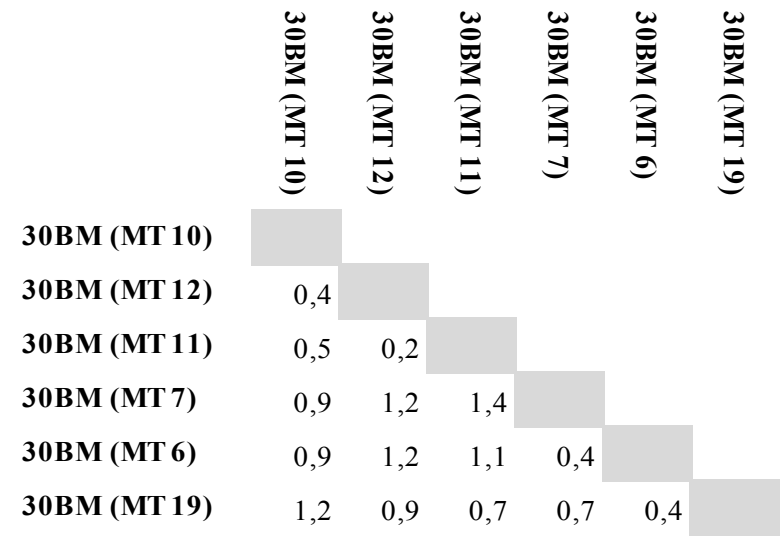

Figura B 21. Porcentagens de divergência entre as sequências do indivíduo 30 BM. 


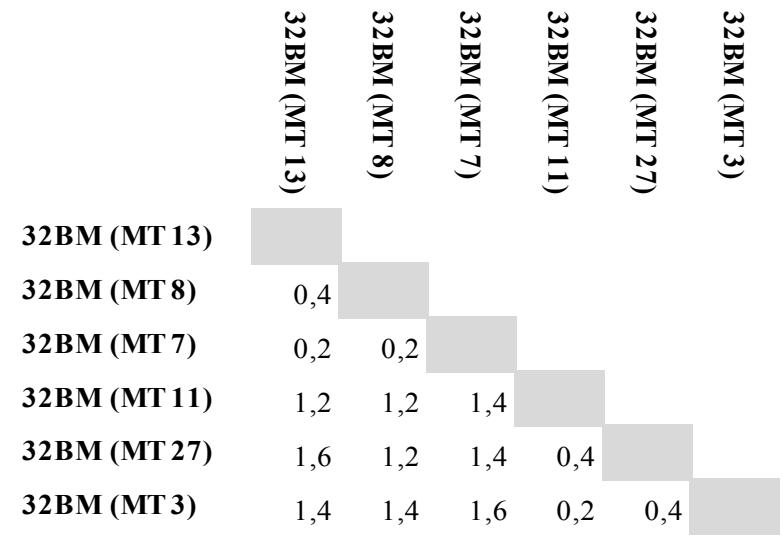

Figura B 22. Porcentagens de divergência entre as sequências do indivíduo 32 BM.

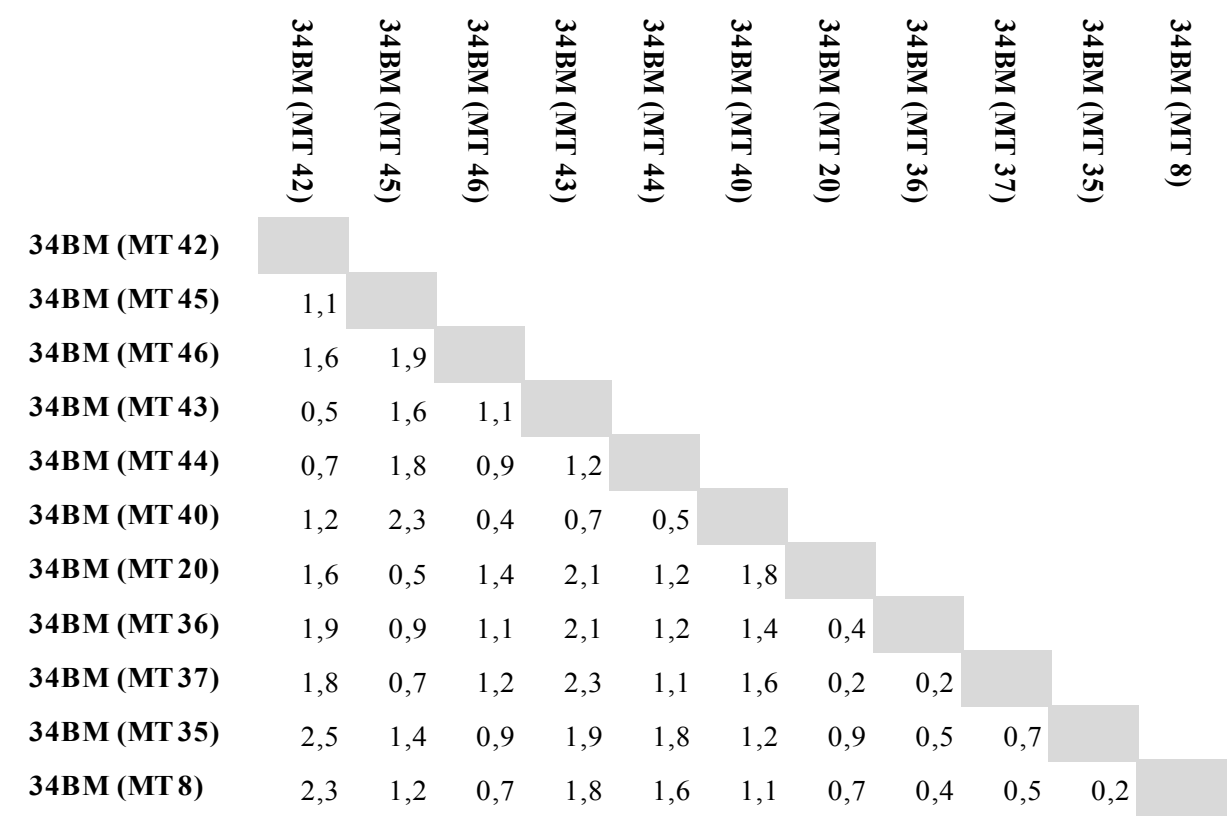

Figura B 23. Porcentagens de divergência entre as sequências do indivíduo 34 BM. 


\title{
Capítulo 3
}

\section{Fidelidade de amplificação de DNA por enzimas DNA polimerase e detecção de variação intraindividual do DNA mitocondrial}

\author{
Paulo Cseri Ricardo ${ }^{1}$, Elaine Françoso ${ }^{1}$ e Maria Cristina Arias ${ }^{1}$ \\ ${ }^{I}$ Departamento de Genética e Biologia Evolutiva - Instituto de Biociências - Universidade de \\ São Paulo, São Paulo, SP, Brasil.
}

\section{Resumo}

A técnica de PCR (Polymerase Chain Reaction) é um método amplamente utilizado para a amplificação in vitro de sequências de DNA. No entanto, durante esse processo, nucleotídeos podem ser erroneamente incorporados, sem respeitar a complementariedade à cadeia molde. Este trabalho investigou como esses erros podem influenciar na identificação da variação intraindividual do DNA mitocondrial (mtDNA). Para tanto, um fragmento do gene mitocondrial COI da espécie Bombus morio (Hymenoptera, Apidae, Bombini) foi amplificado utilizando duas polimerases (Taq e Q5) com fidelidades diferentes, e os produtos dessas PCRs foram clonados. Entre as sequências amplificadas com a Taq DNA polimerase foi observado que os indivíduos apresentaram um haplótipo mais frequente e outros representados por apenas uma sequência (singletons), em geral com poucas mutações em relação ao haplótipo mais frequente. As mutações presentes nesses singletons demonstraram características comuns a erros de amplificação. Por outro lado, dentre as sequências amplificadas utilizando a Q5 DNA polimerase, que apresenta fidelidade superior a Taq, o número de singletons foi menor, e esses haplótipos, em sua maioria, apresentavam características atribuídas a sequências do mtDNA. A partir dessas evidências sugerimos que os erros de amplificação podem superestimar o número de haplótipos, principalmente quando polimerases de baixa fidelidade são utilizadas.

Palavras-chave: Taq DNA polimerase, Q5 DNA polimerase, NUMTs, heteroplasmia. 


\section{Abstract}

The PCR (Polymerase Chain Reaction) is a widely used method enabling the in vitro amplification of DNA sequences. However, during this process failures in nucleotide incorporation may occur. This work investigated how these errors may influence the identification of intraindividual variation on the mitochondrial DNA (mtDNA). Therefore, a fragment of the mitochondrial gene COI of the bumblebee Bombus morio (Hymenoptera, Apidae, Bombini) was amplified using two DNA polymerases (Taq and Q5) with different error rates. The products of those PCRs were cloned. It was observed that amplification with Taq DNA polymerase resulted in several haplotypes being one the most frequent and others represented by only one sequence (singletons), generally with few mutations in relation to the most frequent haplotype. The mutations present in these singletons haplotypes had characteristics commonly related to amplification errors. On the other hand, among the sequences amplified using Q5 DNA polymerase, which shows higher fidelity in comparison to Taq, the number of singletons haplotypes was smaller, and these haplotypes, for the most part, had characteristics attributed to mtDNA sequences. From this evidence, we suggest that amplification errors may overestimate the number of haplotypes, especially when low fidelity polymerases are used.

Keywords: Taq DNA polymerase, Q5 DNA polymerase, NUMTs, heteroplasmy. 


\subsection{Introdução}

A técnica de PCR (Polymerase Chain Reaction), desenvolvida na década de 1980 (SAIKI et al., 1985; MULLIS; FALOONA, 1987), revolucionou a área da biologia molecular. É um método eficaz para a amplificação in vitro de sequências específicas de DNA (ECKERT; KUNKEL, 1991), o que permite, por exemplo, determinar rapidamente o genótipo de uma amostra a partir de pequenas quantidades de tecido (ERLICH; ARNHEIM, 1992). Essa técnica tem sido amplamente utilizada desde em análises clínicas (WHITCOMBE; NEWTON; LITTLE, 1998; DESAI et al., 2006) até em estudos evolutivos (KOCHER; WHITE, 1989). No entanto, erros na incorporação de nucleotídeos podem gerar, ao final de uma PCR, moléculas com sequências diferentes em relação à sequência original (ECKERT; KUNKEL, 1991), e esses erros podem ser interpretados incorretamente como mutações reais. A quantidade de erros em uma reação de PCR depende principalmente da fidelidade da DNA polimerase utilizada, sendo essa fidelidade normalmente expressa pela taxa média de erros por nucleotídeo por replicação (KEOHAVONG; THILLY, 1989).

Os primeiros ensaios de PCR utilizavam uma DNA polimerase extraída da bactéria Escherichia coli (SAIKI et al., 1985). Essa enzima, por ser termolábil, era inativada durante a desnaturação do DNA a temperaturas em torno de $95^{\circ} \mathrm{C}$, portanto, a cada novo ciclo de replicação, a enzima era novamente adicionada, tornando a técnica bem trabalhosa. Posteriormente uma DNA polimerase termoestável foi purificada da bactéria termófila Thermus aquaticus (Taq) (SAIKI et al., 1988). A estabilidade termal da Taq DNA polimerase (Taq-pol) foi crucial para a automatização dessa técnica (REISS et al., 1990), além de aumentar a especificidade e eficiência da reação (SAIKI et al., 1988). Estudos descrevendo a fidelidade da Taq-pol estimam que a taxa de erro dessa enzima varia entre $2 \times 10^{-4}$ (SAIKI et al., 1988; KEOHAVONG; THILLY, 1989) a $2 \times 10^{-5}$ (ECKERT; KUNKEL, 1990; MCINERNEY; ADAMS; HADI, 2014) erros por base por ciclo.

Além da Taq-pol outras DNA polimerases termoestáveis estão disponíveis comercialmente, sendo que algumas possuem fidelidade superior à da Taq. Alguns exemplos são a Vent $\mathbb{R}$ DNA polimerase (New England Biolabs), isolada da espécie de archea Thermococcus litoralis (PERLER et al., 1992), a Pfu DNA polimerase, isolada de outra archea a Pyrococcus furiosus (LUNDBERG et al., 1991), e enzimas resultantes de engenharia genética como a Phusion ${ }^{\circledR}$ (Thermo Fisher Scientific). Essas enzimas possuem atividade exonucleásica 3'- 5', ou seja, atuam na revisão da sequência polimerizada, removendo bases incorporadas incorretamente (KUNKEL, 1992; KUNKEL; BEBENEK, 2000), resultando em taxas de erro 
na ordem de $10^{-6}$ erros por base por ciclo ou inferiores (CLINE, 1996; LI et al., 2006; MCINERNEY; ADAMS; HADI, 2014).

Apesar de serem artefatos esperados na técnica de PCR, normalmente os erros resultantes da amplificação são irrelevantes quando é realizado o sequenciamento direto de uma região, pois estão em baixa frequência na população de moléculas sequenciada (LIN et al., 2002). No entanto, a clonagem de produtos de PCR pode revelar um grande número de clones com pelo menos uma mutação causada por erro de amplificação, principalmente quando se é utilizada uma DNA polimerase com baixa fidelidade (MCINERNEY; ADAMS; HADI, 2014). Por esse motivo, a utilização de DNA polimerases de alta fidelidade é indispensável para diminuir a quantidade de erros de amplificação quando é realizada a clonagem de produtos de PCR (CLINE, 1996), embora seja importante ressaltar que a utilização dessas enzimas não exclui a possibilidade da incorporação de erros.

Os erros de amplificação podem ser interpretados como mutações reais. A clonagem de produtos de PCR pode fazer com que a quantidade de variantes analisadas seja superestimada. Isso representa um problema em estudos que envolvem a coamplificação simultânea de diferentes sequências, como por exemplo, em análises de diversidade de vírus (BRACHO; MOYA; BARRIO, 1998) ou de mutações somáticas (PASCUAL et al., 1994). Da mesma forma os erros de amplificação podem gerar falsos positivos em relação a heteroplasmia e/ou NUMTs (Nuclear mitocondrial pseudogenes). A heteroplasmia é configurada pela presença de mais de um haplótipo mitocondrial em um indivíduo (KMIEC; WOLOSZYNSKA; JANSKA, 2006), enquanto que NUMTs são pseudogenes nucleares originados de sequências do DNA mitocondrial (mtDNA) que foram transferidas para o genoma nuclear (RICHLY; LEISTER, 2004). A presença de NUMTs e de heteroplasmia representam situações diferentes, no entanto, ambas podem interferir negativamente em análises baseadas na amplificação de sequências mitocondriais (SONG et al., 2008; BERTHIER et al., 2011; MAGNACCA; BROWN, 2012; HARAN et al., 2015). Embora a clonagem de produtos de PCR seja propensa a recuperar erros de amplificação, ela é o método mais confiável para investigar a ocorrência de NUMTs e heteroplasmia (BUHAY, 2009), exatamente por isolar as sequências coamplificadas. Este trabalho investigou a ocorrência de erros resultantes da amplificação via PCR em sequências clonadas, e como esses erros podem influenciar na identificação de haplótipos heteroplásmicos e NUMTs, na forma de falsos positivos. Para tanto, foram analisadas as sequências de um fragmento do gene mitocondrial COI da espécie Bombus morio, onde foi constada a presença de heteroplasmia e de NUMTs (ver Capítulo 1). Essas sequências 
foram obtidas após a clonagem de produtos de PCR amplificados por uma Taq DNA polimerase e uma DNA polimerase de alta fidelidade.

\subsection{Metodologia}

\subsubsection{Amostragem e extração de DNA}

Neste trabalho foram utilizados 6 indivíduos de $B$. morio coletados em 4 localidades distintas: Presidente Nereu ( $27^{\circ} 15^{\prime} 34.668^{\prime \prime}$ S 49 $19^{\prime} 46.704^{\prime \prime}$ W) (1BM), Caxias do Sul (29 8' 3.732" S 51 13' 4.152" W) (2BM), Igrapiúna (13 40' 54.588" S 39 9' 53.23" W) (3BM, 4BM e 5BM) e Brasília (1545'41.2"S 4752'18.2"W) (6BM).

O DNA foi extraído da perna traseira de cada indivíduo utilizando o método de isolamento de mitocôndrias descrito por Françoso et al. (2015). Esse método consiste em separar a fração de mitocôndrias do restante do conteúdo celular, utilizando uma pequena quantidade de tecido, com o auxílio de homogeneizador do tipo Dounce, seguido de sucessivas centrifugações. Após o isolamento das mitocôndrias, o mtDNA foi purificado empregando-se o kit DNeasy® Blood \& Tissue (QIAGEN).

\subsubsection{Amplificação}

Os experimentos foram focados em um fragmento de $676 \mathrm{pb}$ do gene mitocondrial da subunidade I do complexo citocromo c oxidase (COI). Esta região foi amplificada para os seis indivíduos de B. morio utilizando os primers BarbeeF (Françoso \& Arias, 2013) e mtD9 (SIMON et al., 1994). Foram realizadas amplificações empregando uma enzima Taq-pol e uma polimerase de alta fidelidade.

A enzima Taq-pol utilizada foi a Platinum ${ }^{\circledR}$ Taq DNA Polymerase (Thermo Fisher Scientific) que, de acordo com seu fabricante, possui uma taxa de erro de $2,28 \times 10^{-5}$ erros por base por ciclo. As amplificações com essa polimerase foram conduzidas sob as seguintes condições: 1,5 mM de $\mathrm{MgCl}_{2}, 0,2 \mathrm{mM}$ de cada dNTP, 0,4 $\mu \mathrm{M}$ de cada primer, 1,5 U de Taq DNA polymerase e $4 \mu \mathrm{l}$ de DNA, em um volume final de $20 \mu \mathrm{l}$. As reações foram realizadas em um Mastercycler ${ }^{\circledR}$ pro (Eppendorf, Germany) e consistiram em uma etapa de desnaturação inicial a $94^{\circ} \mathrm{C}$ por 2 min, seguida por 35 ciclos de $94^{\circ} \mathrm{C}$ por $45 \mathrm{~s}, 48^{\circ} \mathrm{C}$ por $45 \mathrm{~s}$, e $64^{\circ} \mathrm{C}$ por $50 \mathrm{~s}$, e uma extensão final a $64^{\circ}$ por $5 \mathrm{~min}$.

A DNA polimerase de alta fidelidade empregada foi a Q5® High-Fidelity DNA Polymerase, incorporada no kit Q5® High-Fidelity 2X Master Mix (New England Biolabs). Essa polimerase apresenta uma taxa de erro de $5,3 \times 10^{-7}$ erros por base por ciclo (POTAPOV; 
ONG, 2017). As amplificações com essa polimerase foram conduzidas em um volume final de $25 \mu$, utilizando 12,5 $\mu 1$ de Q5 ${ }^{\circledR}$ High-Fidelity $2 \mathrm{X}$ Master Mix, 0,8 $\mu \mathrm{M}$ de cada primer e $4 \mu 1$ de DNA. Essas amplificações também foram realizadas em um Mastercycler ${ }^{\circledR}$ pro (Eppendorf, Germany) e incluíram uma etapa inicial de desnaturação de 30 segundos a $98^{\circ} \mathrm{C}$, seguida por 35 ciclos de $98^{\circ} \mathrm{C}$ por $10 \mathrm{~s}, 50^{\circ} \mathrm{C}$ por $30 \mathrm{~s} \mathrm{e} 72^{\circ} \mathrm{C}$ por $30 \mathrm{~s}$, seguindo as recomendações do fabricante. Ao final dos ciclos seguiu-se uma etapa de extensão a $72^{\circ} \mathrm{C}$ por $2 \min$.

\subsubsection{Clonagem e sequenciamento}

Os amplicons obtidos através da amplificação com a Taq DNA polimerase foram ligados ao vetor plasmidial pGEM® (PROMEGA) seguindo as especificações do fabricante. Devido à atividade exonucleásica 3'- 5' da enzima Q5® High-Fidelity DNA Polymerase, procedimentos adicionais foram realizados, segundo as recomendações do fabricante do vetor plasmidial pGEM® para viabilizar a ligação. Esses procedimentos consistiram na purificação dos produtos de PCR, realizada com o kit QIAquick ${ }^{\circledR}$ PCR Purification (QIAGEN), e a adição de uma cauda poli-A aos amplicons antes da realização da reação de ligação. Bactérias Escherichia coli competentes, da linhagem DH5- $\alpha$, foram transformadas com o vetor recombinante pelo método de choque térmico. Após a transformação as bactérias foram plaqueadas em meio de cultura LB-agar (SAMBROOK; FRITSCH; MANIATIS, 1989) contendo ampicilina $(150 \mathrm{mg} / \mathrm{L})$ e X-gal $(100 \mathrm{mg} / \mathrm{L})$. Para cada indivíduo de B. morio foram isoladas 48, ou mais, colônias. Essas colônias foram transferidas para um microtubo contendo $20 \mu 1$ de tampão TE $(0,5 \mathrm{X})$ e fervidas no termociclador Mastercycler ${ }^{\circledR}$ pro (Eppendorf, Germany) a $99^{\circ} \mathrm{C}$ por 10 minutos. Os insertos clonados foram amplificados utilizando a Platinum ${ }^{\circledR}$ Taq DNA Polymerase (Thermo Fisher Scientific) e os primers pUC/M13 forward (GTTTTCCCAGTCACGAC) e pUC/M13 reverse (CAGGAAACAGCTATGAC), seguindo as mesmas condições utilizadas anteriormente para essa polimerase. Os produtos dessa amplificação foram purificados com a enzima ExoProStar ${ }^{\circledR}$ (GE Healthcare Life Sciences) e encaminhados para sequenciamento, realizado pela empresa Macrogen (Coréia do Sul).

\subsubsection{Quantificação número de haplótipos por indivíduo}

As sequências que apresentaram um índice de qualidade Phred (EWING et al., 1998) inferior a 20 foram excluídas das análises. As selecionadas foram editadas e alinhadas no software GENEIOUS 9.1.6 (KEARSE et al., 2012). A quantificação do número de haplótipos por indivíduo foi realizada no ambiente R 3.3.1 (R CORE TEAM, 2016) utilizando o pacote 
PEGAS 0.9 (PARADIS, 2010). A relação entre os haplótipos foi visualizada a partir de redes de haplótipos construídas pelo programa POPART 1.7 (LEIGH; BRYANT, 2015), utilizando o algoritmo median-joining (BANDELT; FORSTER; ROHL, 1999).

\subsubsection{Estimativa da frequência de erros}

A frequência de produtos de PCR com um erro de amplificação foi estimada utilizando a equação apresentada por Smith e Modrich (1997), que por sua vez foi baseada nas equações descritas por Luria e Delbrück (1943):

$$
f=2^{\ln a}
$$

onde $f$ é a porcentagem esperada de produtos de PCR que apresentem um erro, $l$ o tamanho em pares de bases do fragmento amplificado, $n$ o número de ciclos utilizados na amplificação e $a$ a taxa de erro da polimerase. Essas estimativas foram comparadas com os resultados obtidos, a fim de observar quantos haplótipos recuperados poderiam ser resultado de erros de amplificação. Essas comparações foram realizadas utilizando o teste t-Student implementado no ambiente R 3.1.1.

\subsection{Resultados}

As análises das sequências do COI amplificadas com a Platinum ${ }^{\circledR}$ Taq DNA Polymerase revelaram a presença de um grande número de haplótipos para cada indivíduo, sendo que a maioria desses haplótipos foram singletons, ou seja, haplótipos representados por apenas uma sequência (Tabela 3.1). A maioria desses singletons diferiu em um único passo mutacional em relação a um haplótipo mais frequente, definindo um padrão de "estrela" na rede de haplótipos (Figura 3.1A-F). Contudo também foram observados em alguns indivíduos a presença de singletons com vários passos mutacionais em relação aos demais haplótipos.

Tabela 3. 1. Relação entre os indivíduos e número de clones sequenciados ( $\mathrm{N}$ seq) e haplótipos (h) recuperados para cada DNA polimerase.

\begin{tabular}{ccccccc}
\hline \multirow{2}{*}{ Indivíduo } & \multicolumn{3}{c}{ Taq DNA polimerase } & \multicolumn{3}{c}{ Q5® DNA Polymerase } \\
& N seq & $\mathrm{h}$ & Singletons & $\mathrm{N} \mathrm{seq}$ & $\mathrm{h}$ & Singletons \\
\hline 1BM & 43 & 24 & 22 & 39 & 15 & 10 \\
2BM & 42 & 19 & 18 & 44 & 1 & 0 \\
3BM & 45 & 21 & 17 & 42 & 23 & 19 \\
4BM & 45 & 30 & 28 & 59 & 17 & 11 \\
5BM & 23 & 21 & 20 & 54 & 14 & 6 \\
6BM & 19 & 11 & 9 & 43 & 6 & 3 \\
\hline
\end{tabular}

* Singletons são sequências únicas na amostra. 
Os resultados obtidos a partir da amplificação com o kit Q5® High-Fidelity 2 X Master Mix apresentaram uma diferença significativa $(p$-value $=0,00384)$ na frequência de singletons em relação aos resultados obtidos pela Taq DNA polimerase, sendo que para todos os indivíduos, exceto 3BM, ocorreu a diminuição no número de singletons (Tabela 3.1). Além disso, para os singletons recuperados não foi observada uma distribuição no padrão de "estrela" (Figura 3.1G-L), e o indivíduo 2BM apresentou apenas um único haplótipo mitocondrial (Figura 3.1H). Também foram recuperados haplótipos com muitos passos mutacionais em relação aos demais nos indivíduos 3BM, 4BM e 5BM (Figura 3.1I-K).

Segundo as estimativas calculadas, era esperado que 53,94\% dos produtos de PCR amplificados com o uso da Taq-pol apresentassem um erro. Para a Taq não foi encontrada diferença significativa entre a frequência estimada de sequências com erros e a quantidade de haplótipos ou em relação a quantidade de singletons. Já a estimativa para os produtos amplificados com a Q5 indicou que 1,25\% dos produtos poderiam ter incorporado um erro. Para essa polimerase foi observada diferença significativa $(p$-value $=0,01763)$ entre a quantidade de haplótipos e a frequência estimada de sequências com erros de amplificação. A diferença encontrada entre a quantidade de singletons e a frequência estimada de sequências com erros resultou em um valor marginalmente significativo ( $p$-value $=0,05185$ ). 
A

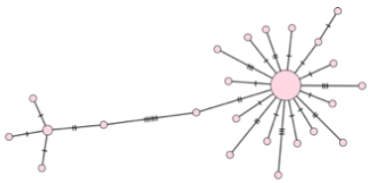

B

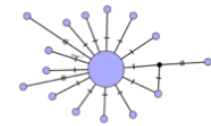

C

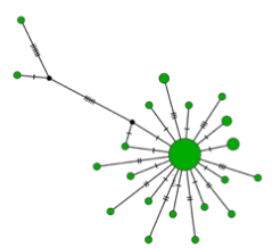

D

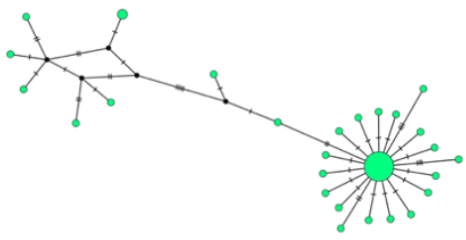

E

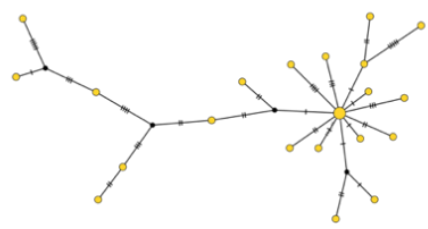

F

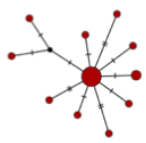

G

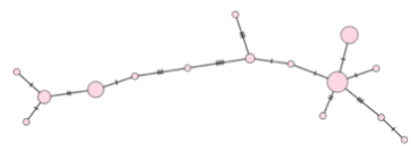

H

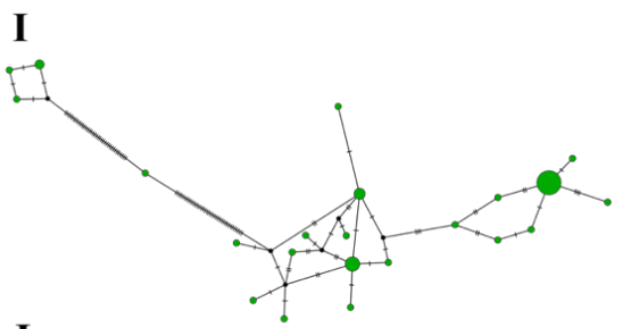

J

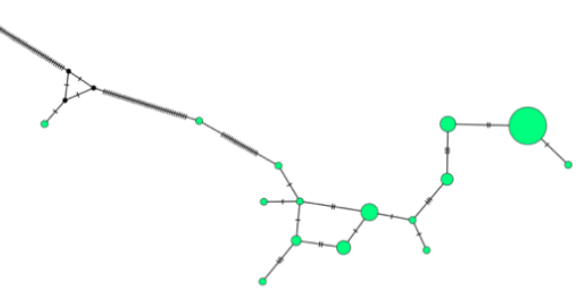

K

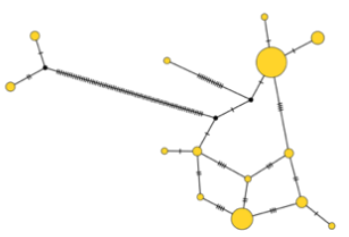

L

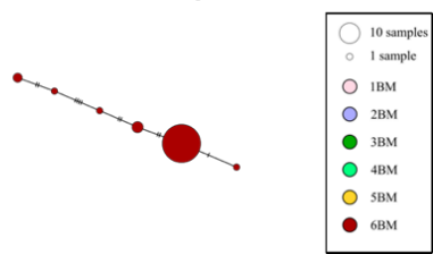

Figura 3.1. Redes de relação entre os haplótipos intraindividuais, construídas utilizando uma região do $C O I$ para seis indivíduos de B. morio (as cores representam indivíduos diferentes). A-F Redes construídas a partir de sequências amplificadas com a Platinum ${ }^{\circledR}$ Taq DNA Polymerase. G-L Redes construídas a partir de sequências amplificadas com o kit Q5 ${ }^{\circledR}$ High-Fidelity 2X Master Mix. Cada círculo representa um haplótipo distinto e o seu tamanho é proporcional a sua frequência. As barras transversais indicam o número de passos mutacionais entre os haplótipos.

O número de mutações sinônimas e não sinônimas entre as sequências recuperadas para cada indivíduo foi quantificado. Quando a Taq foi utilizada notou-se que o número de mutações não sinônimas entre as sequências em geral foi superior ao de mutações sinônimas, além de que foram observados indels em várias sequências (Tabela 3.2). Por outro lado, na maioria das sequências amplificadas com a Q5, as mutações ocorreram preferencialmente na terceira base do códon, e o número de mutações sinônimas foi superior ao de não sinônimas. Como dentre essas sequências alguns haplótipos foram muito divergentes dos demais (variando de $2,6 \%$ a $11,8 \%$ ), o número total de mutações foi superior ao observado nas amplificações 
com a Taq-pol. Afim de verificar se a presença desses haplótipos estavam enviesando na razão entre mutações sinônimas e não sinônimas, o número de mutações também foi quantificado sem a presença desses haplótipos mais divergentes. Mesmo quando esses haplótipos foram desconsiderados o número de mutações sinônimas foi superior ao de mutações não sinônimas.

Tabela 3.2. Mutações verificadas entre as sequências recuperadas para cada indivíduo utilizando a Taq DNA polimerase e a Q5® DNA Polymerase.

\begin{tabular}{lllllll}
\hline \multirow{2}{*}{ Indivíduo } & \multicolumn{3}{c}{ Taq DNA polimerase } & \multicolumn{3}{c}{ Q5® DNA Polymerase } \\
& Sinônima & Não sinônima & Indels & Sinônima & Não sinônima & Indels \\
\hline 1BM & 19 & 17 & - & 12 & 5 & - \\
2BM & 9 & 10 & 5 & - & - & - \\
3BM & 17 & 26 & 2 & $53\left(12^{*}\right)$ & $33\left(6^{*}\right)$ & $2\left(1^{*}\right)$ \\
4BM & 17 & 24 & 4 & $60\left(8^{*}\right)$ & $30\left(4^{*}\right)$ & $2(1 *)$ \\
5BM & 21 & 20 & 2 & $57\left(9^{*}\right)$ & $36\left(2^{*}\right)$ & $2\left(0^{*}\right)$ \\
6BM & 5 & 9 & 1 & 9 & 0 & - \\
\hline
\end{tabular}

*Valores obtidos após a exclusão dos haplótipos mais divergentes.

Também foram observadas as substituições presentes nos singletons das amostras amplificadas com a Taq, uma vez que essa enzima apresenta um viés no tipo de substituição (ECKERT; KUNKEL, 1990). As substituições mais frequentes foram transições A·T $\rightarrow$ G·C $(62 \%)$, seguidas de substituições $\mathrm{A} \cdot \mathrm{T} \rightarrow \mathrm{T} \cdot \mathrm{A}(18 \%), \mathrm{G} \cdot \mathrm{C} \rightarrow \mathrm{A} \cdot \mathrm{T}(10 \%), \mathrm{G} \cdot \mathrm{C} \rightarrow \mathrm{T} \cdot \mathrm{A}(6 \%)$ e $A \cdot T \rightarrow C \cdot G(4 \%)$.

\subsection{Discussão}

Os erros de amplificação podem superestimar o número de haplótipos intraindividuais. Isso fica evidente quando utilizado a Taq-pol, onde a maior parte dos haplótipos recuperados constituíram em singletons distribuídos em um padrão de "estrela". A frequência desses singletons não apresentou diferença significativa em relação à frequência estimada para sequências com um erro, dessa forma é possível que esses singletons sejam resultados de erros na incorporação de nucleotídeos. Além disso, as mutações observadas nas sequências desses singletons foram predominantemente transições $\mathrm{A} \cdot \mathrm{T} \rightarrow \mathrm{G} \cdot \mathrm{C}$. Vários trabalhos documentaram que a Taq apresenta um viés para esse tipo de substituição (SAIKI et al., 1988; KEOHAVONG; THILLY, 1989; ECKERT; KUNKEL, 1990; BRACHO; MOYA; BARRIO, 1998), sendo que as frequências dessas transições variam entre 57\% (DUNNING; TALMUD; HUMPHRIES, 1988; ENNIS et al., 1990) e 66\% (BRACHO; MOYA; BARRIO, 1998; POTAPOV; ONG, 2017). Isso reforça a possibilidade de que esses singletons realmente configurem erros de amplificação. 
Os resultados obtidos com a polimerase de alta fidelidade apresentaram menos singletons que as amplificações utilizando a Taq polimerase. No entanto, utilizando a Q5, para a maioria das amostras a frequência dos singletons foi superior à frequência estimada de sequências com erros, e a diferença observada entre essas frequências apresentou valor marginalmente significativo, portanto, não é possível atribuir com confiança a frequência de singletons a erros de amplificação. Ainda, a maioria desses singletons apresentou vários passos mutacionais em relação a outros haplótipos, o que é uma evidência de serem haplótipos mitocondriais intraindividuais reais, ou ainda NUMTs (no caso das sequências muito distintas observadas nos indivíduos 3BM, 4BM e 5BM), já que a taxa de erro apresentada pela Q5 não é suficiente para gerar o número de mutações necessário para a existência de todos esses haplótipos. Em comparação com a Taq as amplificações realizadas com a enzima Q5 resultaram em um número maior de haplótipos presentes mais de uma vez na amostragem de clones, esse fato também reforça que sejam haplótipos intraindividuais reais. É possível que essa diferença seja resultado da concentração de primers utilizada, que foi superior à utilizada para a amplificação com a Taq DNA polimerase, permitindo o anelamento com um número maior de moléculas diferentes.

A exclusão dos singletons pode minimizar a ocorrência de falsos positivos tratando-se da identificação de haplótipos intraindividuais. No entanto, essa abordagem pode apresentar alguns inconvenientes que devem ser considerados. É possível que haplótipos representados por mais de uma sequência também sejam resultado de erros na incorporação de nucleotídeos. Os erros de amplificação que ocorrem nos primeiros ciclos apresentam grande efeito na composição das sequências presentes na população de moléculas ao final de uma PCR (REISS et al., 1990), podendo apresentar frequência superior à esperada. Assim, mesmo a exclusão de singletons não elimina a possibilidade de falsos positivos. Além disso, a exclusão de singletons também pode representar a retirada de haplótipos intraindividuais reais das análises. Porém, haplótipos únicos com vários passos mutacionais em relação a um haplótipo mais frequente provavelmente representam haplótipos intraindividuais reais, pois é pouco provável a inserção de vários erros em uma mesma sequência, mesmo quando são utilizadas polimerases com baixa fidelidade. Dessa forma, a manutenção desse tipo de singleton é justificável.

A análise de mutações também pode auxiliar na identificação de falsos positivos, especialmente tratando-se de heteroplasmia, uma vez que, mesmo em sequências heteroplásmicas, as mutações no mtDNA tendem a se acumular na terceira base do códon (ver Capítulo 1). Os erros de amplificação, por sua vez, se distribuem aleatoriamente na sequência, independentemente da posição do códon (BRACHO; MOYA; BARRIO, 1998). A presença de 
indels também pode ser um indicativo de erros de amplificação, uma vez que estes resultam na mudança do quadro de leitura, o que na maioria das vezes reflete em sequências não funcionais. No entanto, essas características também podem estar presentes nas sequências de NUMTs, já que após a transferência para o núcleo, onde não são funcionais, essas sequências não estão sobre as mesmas pressões seletivas que ocorrem no mtDNA (BENSASSON et al., 2001). Assim, levando em consideração essas características NUMTs podem ser confundidos com erros de amplificação, principalmente quando a transferência dessas sequências para o DNA nuclear (nuDNA) ocorreu recentemente. Isso porque no nuDNA essas sequências evoluem mais lentamente que no mtDNA (ZHANG; HEWITT, 1996), e em um pequeno espaço de tempo nenhuma ou poucas mutações tendem a se acumular, fazendo com que NUMTs recentes sejam muito similares a sequências mitocondriais (GOIOS; CARVALHO; AMORIM, 2009).

A quantidade de singletons, especialmente aqueles que apresentam poucas mutações, se mostrou relacionada com a taxa de fidelidade da DNA polimerase utilizada. Dessa forma, as mutações encontradas nesses singletons provavelmente representam erros de amplificação. Em estudos que investigam a presença de variação intraindividual do mtDNA isso é de grande importância, uma vez que esses singletons podem configurar falsos positivos. A utilização de uma enzima de alta fidelidade pode diminuir consideravelmente o número de possíveis falsos positivos, no entanto, não exime a possibilidade da ocorrência dos mesmos. Assim, apesar das desvantagens apresentadas, a exclusão de singletons, principalmente quando apresentam uma única mutação em relação a um haplótipo mais frequente, representa a melhor estratégia para evitar a influência dos erros de amplificação na identificação de variação intraindividual do mtDNA.

\subsection{Referências Bibliográficas}

BANDELT, H. J.; FORSTER, P.; ROHL, A. Median-joining networks for inferring intraspecific phylogenies. Molecular Biology and Evolution, v. 16, n. 1, p. 37-48, 1999.

BENSASSON, D.; ZHANG, D.-X.; HARTL, D. L.; HEWITT, G. M. Mitochondrial pseudogenes: Evolution's misplaced witnesses. Trends in Ecology and Evolution, v. 16, n. 6, p. 314-321, 2001.

BERTHIER, K.; CHAPUIS, M. P.; MOOSAVI, S. M.; TOHIDI-ESFAHANI, D.; SWORD, G. A. Nuclear insertions and heteroplasmy of mitochondrial DNA as two sources of intraindividual genomic variation in grasshoppers. Systematic Entomology, v. 36, n. 2, p. 285-299, 2011.

BRACHO, M. A.; MOYA, A.; BARRIO, E. Contribution of Taq polymerase-induced errors to the estimation of RNA virus diversity. Journal of General Virology, v. 79, n. 12, p. 2921- 
2928, 1998.

BUHAY, J. E. "COI-like" sequences are becoming problematic in molecular systematic and DNA barcoding studies. Journal of Crustacean Biology, v. 29, n. 1, p. 96-110, 2009.

CLINE, J. PCR fidelity of $P f u$ DNA polymerase and other thermostable DNA polymerases. Nucleic Acids Research, v. 24, n. 18, p. 3546-3551, 1996.

DESAI, D.; NATARAJ, G.; KULKARNI, S.; BICHILE, L.; MEHTA, P.; BAVEJA, S.; RAJAN, R.; RAUT, A.; SHENOY, A. Utility of the polymerase chain reaction in the diagnosis of tuberculous meningitis. Research in Microbiology, v. 157, n. 10, p. 967-970, 2006.

DUNNING, A. M.; TALMUD, P.; HUMPHRIES, S. E. Errors in the Polymerase Chain Reaction. Nucleic Acids Research, v. 16, n. 21, p. 10393, 1988.

ECKERT, K. A.; KUNKEL, T. A. High fidelity DNA synthesis by the Thermus aquaticus DNA polymerase. Nucleic Acids Research, v. 18, n. 13, p. 3739-3744, 1990.

ECKERT, K. A.; KUNKEL, T. A. DNA polymerase fidelity and the polymerase chain reaction. PCR Methods and Applications, v. 1, n. 1, p. 17-24, 1991.

ENNIS, H. L.; ZEMMOUR, J.; SALTER, R. D.; PARHAM, P. Rapid cloning of HLA-A,B cDNA by using the polymerase chain reaction: Frequency and nature of errors produced in amplification. Proceedings of the National Academy of Sciences, v. 87, n. 7, p. 2833-2837, 1990.

ERLICH, H. A.; ARNHEIM, N. Genetic analysis using the Polymerase Chain Reaction. Annual Review of Genetics, v. 26, n. 1, p. 479-506, 1992.

EWING, B.; HILLIER, L.; WENDL, M. C.; GREEN, P. Base-calling of automated sequencer traces using phred. I. Accuracy assessment. Genome Research, v. 8, n. 3, p. 175-185, 1998.

FRANÇOSO, E.; ARIAS, M. C. Cytochrome c oxidase I primers for corbiculate bees: DNA barcode and mini-barcode. Molecular Ecology Resources, v. 13, n. 5, p. 844-850, 2013.

FRANÇOSO, E.; GOMES, F.; ARIAS, M. C. A protocol for isolating insect mitochondrial genomes: a case study of NUMT in Melipona flavolineata (Hymenoptera: Apidae). Mitochondrial DNA, v. 27, n. 4, p. 1-4, 2015.

GOIOS, A.; CARVALHO, A.; AMORIM, A. Identifying NUMT contamination in mtDNA analyses. Forensic Science International: Genetics Supplement Series, v. 2, n. 1, p. 278$280,2009$.

HARAN, J.; KOUTROUMPA, F.; MAGNOUX, E.; ROQUES, A.; ROUX, G. Ghost mtDNA haplotypes generated by fortuitous NUMTs can deeply disturb infra-specific genetic diversity and phylogeographic pattern. Journal of Zoological Systematics and Evolutionary Research, v. 53, n. 2, p. 109-115, 2015.

KEARSE, M.; MOIR, R.; WILSON, A.; STONES-HAVAS, S.; CHEUNG, M.; STURROCK, S.; BUXTON, S.; COOPER, A.; MARKOWITZ, S.; DURAN, C.; THIERER, T.; ASHTON, 
B.; MEINTJES, P.; DRUMMOND, A. Geneious Basic: An integrated and extendable desktop software platform for the organization and analysis of sequence data. Bioinformatics, v. 28, n. 12, p. 1647-1649, 2012.

KEOHAVONG, P.; THILLY, W. G. Fidelity of DNA polymerases in DNA amplification. Proceedings of the National Academy of Sciences, v. 86, n. 23, p. 9253-9257, 1989.

KMIEC, B.; WOLOSZYNSKA, M.; JANSKA, H. Heteroplasmy as a common state of mitochondrial genetic information in plants and animals. Current Genetics, v. 50, n. 3, p. 149159, 2006.

KOCHER, T. D.; WHITE, T. J. Evolutionary analysis via PCR. In: PCR Technology. London: Palgrave Macmillan UK, 1989. p. 137-147.

KUNKEL, T. A. DNA replication fidelity. Journal of Biological Chemistry, v. 267, n. 26, p. 18251-18254, 1992.

KUNKEL, T. A.; BEBENEK, K. DNA replication fidelity. Annual Review of Biochemistry, v. 69, n. 1, p. $497-529,2000$.

LEIGH, J. W.; BRYANT, D. Popart: full-feature software for haplotype network construction. Methods in Ecology and Evolution, v. 6, n. 9, p. 1110-1116, 2015.

LI, M.; DIEHL, F.; DRESSMAN, D.; VOGELSTEIN, B.; KINZLER, K. W. BEAMing up for detection and quantification of rare sequence variants. Nature Methods, v. 3, n. 2, p. 95-97, 2006.

LIN, M. T.; SIMON, D. K.; AHN, C. H.; KIM, L. M.; BEAL, M. F. High aggregate burden of somatic mtDNA point mutations in aging and Alzheimer's disease brain. Human Molecular Genetics, v. 11, n. 2, p. 133-145, 2002.

LUNDBERG, K. S.; SHOEMAKER, D. D.; ADAMS, M. W. W.; SHORT, J. M.; SORGE, J. A.; MATHUR, E. J. High-fidelity amplification using a thermostable DNA polymerase isolated from Pyrococcus furiosus. Gene, v. 108, n. 1, p. 1-6, 1991.

LURIA, S. E.; DELBRÜCK, M. Mutations of bacteria from virus sensitivity to virus resistance. Genetics, v. 28, n. 6, p. 491-511, 1943.

MAGNACCA, K. N.; BROWN, M. J. F. DNA barcoding a regional fauna: Irish solitary bees. Molecular Ecology Resources, v. 12, n. 6, p. 990-998, 2012.

MCINERNEY, P.; ADAMS, P.; HADI, M. Z. Error rate comparison during Polymerase Chain Reaction by DNA polymerase. Molecular Biology International, v. 2014, p. 1-8, 2014.

MULLIS, K. B.; FALOONA, F. A. Specific Synthesis of DNA in Vitro via a PolymeraseCatalyzed Chain Reaction. Methods in Enzymology, v. 155, n. C, p. 335-350, 1987.

PARADIS, E. pegas: an $\mathrm{R}$ package for population genetics with an integrated-modular approach. Bioinformatics, v. 26, n. 3, p. 419-420, 2010. 
PASCUAL, V.; LIU, Y. J.; MAGALSKI, A.; DE BOUTEILLER, O.; BANCHEREAU, J.; CAPRA, J. D. Analysis of somatic mutation in five B cell subsets of human tonsil. Journal of Experimental Medicine, v. 180, n. 1, p. 329-339, 1994.

PERLER, F. B.; COMB, D. G.; JACK, W. E.; MORAN, L. S.; QIANG, B.; KUCERA, R. B.; BENNER, J.; SLATKO, B. E.; NWANKWO, D. O.; HEMPSTEAD, S. K. Intervening sequences in an Archaea DNA polymerase gene. Proceedings of the National Academy of Sciences, v. 89, n. 12, p. 5577-5581, 1992.

POTAPOV, V.; ONG, J. L. Examining sources of error in PCR by single-molecule sequencing. PLoS ONE, v. 12, n. 1, p. e0169774, 2017. doi: 10.1371/journal.pone.0169774

R CORE TEAM. R: A Language and Environment for Statistical Computing. Vienna, Austria, 2016. Disponível em: < http://www.r-project.org/>.

REISS, J.; KRAWCZAK, M.; SCHLOESSER, M.; WAGNER, M.; COOPER, D. N. The effect of replication errors on the mismatch analysis of PCR-amplified DNA. Nucleic Acids Research, v. 18, n. 4, p. 973-978, 1990.

RICHLY, E.; LEISTER, D. NUMTs in sequenced eukaryotic genomes. Molecular Biology and Evolution, v. 21, n. 6, p. 1081-1084, 2004.

SAIKI, R.; GELFAND, D.; STOFFEL, S.; SCHARF, S.; HIGUCHI, R.; HORN, G.; MULLIS, K.; ERLICH, H. Primer-directed enzymatic amplification of DNA with a thermostable DNA polymerase. Science, v. 239, n. 4839, p. 487-491, 1988.

SAIKI, R.; SCHARF, S.; FALOONA, F.; MULLIS, K.; HORN, G.; ERLICH, H.; ARNHEIM, N. Enzymatic amplification of beta-globin genomic sequences and restriction site analysis for diagnosis of sickle cell anemia. Science, v. 230, n. 4732, p. 1350-1354, 1985.

SAMBROOK, J.; FRITSCH, E. F.; MANIATIS, T. Molecular cloning: A laboratory manual. 2. ed. New York: Cold Spring Harbor Laboratory Press, 1989. v. 3

SIMON, C.; FRATI, F.; BECKENBACH, A.; CRESPI, B.; LIU, H.; FLOOK, P. Evolution, weighting, and phylogenetic utility of mitochondrial gene sequences and a compilation of conserved polymerase chain reaction primers. Annals of the Entomological Society of America, v. 87, n. 6, p. 651-701, 1994.

SMITH, J.; MODRICH, P. Removal of polymerase-produced mutant sequences from PCR products. Proceedings of the National Academy of Sciences, v. 94, n. 13, p. 6847-6850, 1997.

SONG, H.; BUHAY, J. E.; WHITING, M. F.; CRANDALL, K. A. Many species in one: DNA barcoding overestimates the number of species when nuclear mitochondrial pseudogenes are coamplified. Proceedings of the National Academy of Sciences, v. 105, n. 36, p. 1348613491, 2008.

WHITCOMBE, D.; NEWTON, C. R.; LITTLE, S. Advances in approaches to DNA-based diagnostics. Current Opinion in Biotechnology, v. 9, n. 6, p. 602-608, 1998.

ZHANG, D.-X.; HEWITT, G. M. Nuclear integrations: challenges for mitochondrial DNA 
markers. Trends in Ecology \& Evolution, v. 11, n. 6, p. 247-251, 1996. 


\section{Conclusões Gerais}

1. A heteroplasmia em Bombus morio parece ser estável, pois vários haplótipos heteroplásmicos foram compartilhados por indivíduos de localidades geograficamente distantes.

2. A heteroplasmia representa um desafio para estudos populacionais e filogeográficos, pois pode gerar ambiguidades durante a análise de sequências do mtDNA. Essas ambiguidades podem interferir na topologia de redes de haplótipos e filogenias, como foi observado para os indivíduos de Teodoro Sampaio, que apesar de possuirem haplótipos geneticamente distantes do restante da amostragem, também apresentaram haplótipos compartilhados com indivíduos das demais localidades. Ademais, mesmo quando a presença de heteroplasmia é identificada a escolha de um haplótipo único para um indivíduo baseado em sua frequência pode levar a inferências imprecisas.

3. Os NUMTs podem afetar profundamente análises filogenéticas e populacionais baseadas em sequências do mtDNA, principalmente quando a transferência dessas sequências para o genoma nuclear ocorreu há muito tempo. Da mesma forma apresentam grande potencial negativo na identificação de espécies por meio da estratégia do DNA barcoding.

4. NUMTs antigos tendem a apresentar diferenças que facilitam a distinção dessas sequências de sequências mitocondriais, tais como mudanças no quadro de leitura, mutações independentes da posição do códon, e elevada divergência em relação às sequências mitôcondriais atuais.

5. A identificação da heteroplasmia pode ser comprometida por erros de amplificação, já que esses erros podem ser confundidos com variação intraindividual, superestimando o número de haplótipos heteroplásmicos.

6. Sequências com erros de amplificação em geral apresentam poucas mutações (frequentemente não sinônimas) em relação à sequência de um haplótipo mais frequente, gerando um padrão de "estrela" em uma rede de haplótipos. Recomenda-se a exclusão de sequências com esse padrão em estudos que investiguem heteroplasmia. 